Proceedings of the Prehistoric Society 84, 2018, pp. 145-184 (C) The Prehistoric Society. This is an Open Access article, distributed under the terms of the Creative Commons Attribution licence (http://creativecommons.org/ licenses/by/4.0/), which permits unrestricted reuse, distribution, and reproduction in any medium, provided the original work is properly cited.

doi:10.1017/ppr.2018.8 First published online 02 October 2018

\title{
Deforestation and Human Agency in the North Atlantic Region: Archaeological and Palaeoenvironmental Evidence from the Western Isles of Scotland
}

\author{
By ROSIE R. BISHOP ${ }^{1,2}$, MIKE J. CHURCH ${ }^{2}$, IAN T. LAWSON ${ }^{3}$, KATHERINE H. ROUCOUX ${ }^{3}$, CHARLOTTE O'BRIEN ${ }^{2}$ \\ HELEN RANNER ${ }^{4}$, ANDREW J. HEALD ${ }^{5}$ and CATHERINE E. FLITCROFT $^{6}$
}

This paper considers the timing and mechanisms of deforestation in the Western Isles of Scotland, focusing in particular on the landscape around the Calanais stone circles, one of the best preserved late Neolithiclearly Bronze Age monumental landscapes in north-west Europe. We present new archaeological and palaeoenvironmental evidence from a soil and peat sequence at the site of Aird Calanais, which spans the main period of use of the Calanais circles. We then draw on a new synthesis of archaeobotanical and palynological evidence from across the Western Isles and a review of comparable data from the wider North Atlantic zone, before assessing the role of early farming communities in clearing the wooded landscapes of the region. Pollen and radiocarbon dating at the site of Aird Calanais reveal that a layer of birch branches, dating to the late Neolithic (2912-2881 cal BC), was contemporaneous with a decline in woodland at the site, as well as with the major phase of Neolithic activity at the Calanais stone circle complex. However, our synthesis of the pollen and plant macrofossil evidence from across the Western Isles suggests that the picture across these islands was altogether more complex: woodlands declined both before, as well as during, the Neolithic and deciduous woodlands remained sufficiently abundant for Neolithic fuel procurement. Finally, we consider the implications of the results for understanding the interactions between first farmers and woodlands in the wider North Atlantic region.

Keywords: Neolithic, deforestation, archaeobotany, palynology, radiocarbon dating, Western Isles of Scotland; North Atlantic islands

The timing and mechanisms of the development of today's treeless landscapes in the North Atlantic islands have important implications for establishing

\footnotetext{
${ }^{1}$ School of Archaeology, University College Dublin, Newman Building, Belfield, Dublin 4, Ireland.

Email: rosie.bishop@ucd.ie.

${ }^{2}$ Department of Archaeology, Durham University, South Road, Durham, DH1 3LE, UK

${ }^{3}$ School of Geography \& Geosciences, Irvine Building, St Andrews, KY16 9AL, UK

${ }^{4}$ Coatesgarth, Boldron, Barnard Castle, County Durham, DL12 9RF, UK

${ }^{5}$ AOC Archaeology Group, Edgefield Road Industrial Estate, Loanhead, Midlothian, EH20 9SY UK

${ }^{6}$ British Mountaineering Council, 177-179 Burton Road, Manchester, M20 2BB, UK
}

the nature of human-woodland interaction in landscapes of settlement (Dugmore et al. 2005; Church et al. 2007a). Understanding the history of deforestation also helps us to understand past and present-day trajectories of environmental change, and to set conservation priorities and carbon management strategies (Bennett et al. 1997; Lawson et al. 2005; SNH 2014). Deforestation had profound long-term effects for farming communities in the North Atlantic region, ultimately reducing the area of land suitable for agriculture through soil erosion or the spread of blanket bog, and creating challenges for fuel and timber procurement strategies. It is often suggested that the introduction of agriculture by the first farming groups in the Neolithic period (c. 3800-3600 cal BC) in the Western Isles, Orkney and Shetland, and later 
(9th-11th centuries cal AD) by Norse settlers in the Faroes, Iceland, and Greenland, led swiftly to widespread deforestation (eg, McGovern et al. 1988; Bennett et al. 1997; Dickson 2000; Diamond 2005; Dugmore et al. 2005). However, palynological evidence from many parts of the region suggests that woodland decline was often more protracted, with woodlands surviving in some locations for many centuries or millennia (Edwards et al. 2000; Church et al. 2007a; Lawson et al. 2007b; Schofield \& Edwards 2011; Farrell et al. 2014).

The Western Isles (also known as the Outer Hebrides) represent a key island group for examining the nature of the earliest farmers' interactions with woodlands in the North Atlantic region. As the southernmost archipelago of the North Atlantic Islands, the Western Isles are positioned at one end of an environmental gradient extending from the temperate conditions in Atlantic Scotland to the arctic conditions of Greenland, and they were amongst the earliest islands of the region to have been settled by farmers. Contrary to modern perceptions of the marginality of the Western Isles, they preserve one of the largest and best-preserved concentrations of Neolithic and Bronze Age monuments and agricultural features in north-west Europe. At Calanais on Lewis these features include stone circles, stone alignments, standing stones and chambered cairns, cultivation beds, stone field boundaries, palaeosols, and clearance cairns (Cowie 1994; Ashmore 1995; 2016; Coles et al. 1998; Johnson et al. 2000). The most impressive of the surviving monuments is Calanais I, a large stone circle with cruciform stone alignments, where the major phase of construction and use was in the late Neolithic-Bronze Age (c. 3000-1700 cal BC: Ashmore 1995; 2016). Survey and excavation within the wider Calanais landscape have also revealed settlement evidence ranging from prehistoric hut circles to postmedieval 'blackhouses' (Coles 1993a; 1993b; Coles \& Burgess 1994). The encroachment of peat over these sites has reduced modern interference, aiding preservation, and, fortuitously, providing material suitable for palaeoenvironmental sampling. The richness of the evidence base therefore supports detailed research into the history of human-environment interactions.

Though the present landscapes of the Western Isles are open and virtually tree-less, palaeoenvironmental evidence suggests that during the Mesolithic period (c. 9600-4000 cal BC) the islands supported substantial birch-hazel woodlands (Bennett et al. 1997; Church 2006). The chronology and causes of the deforestation have been much debated, with palynological evidence suggesting that both the initial woodland coverage and subsequent woodland decline were spatially and temporally variable (Brayshay \& Edwards 1996; Fossitt 1996; Edwards et al. 2000; Fyfe et al. 2013). It has also been suggested that there was a degree of economic continuity between Mesolithic and Neolithic lifestyles in the region (Armit \& Finlayson 1992, 67; Thomas 1999, 7-17; 2013, 402) and hence woodland impacts (eg, Edwards 1996). Therefore, the extent to which Neolithic communities in the Western Isles were responsible for the woodland decline remains uncertain.

This paper presents new archaeological and palaeoenvironmental data from Aird Calanais, a site within the Calanais landscape that spans the period of use of the Calanais stones. We consider the timing, causes and significance of deforestation both locally (Aird Calanais) and regionally (Western Isles and beyond), starting with the new evidence from Aird Calanais, and then developing a new synthesis of plant macrofossil and pollen evidence from the Western Isles and a review of comparable data from the wider North Atlantic region. The following research questions are addressed:

1. How and when was the archaeological material at Aird Calanais formed?

2. What were the timing, nature and mechanisms of deforestation in the Calanais landscape?

3. What does the regional plant macrofossil and pollen evidence reveal about the timing, extent, and mechanisms for woodland decline in the Western Isles?

4. What implications does the evidence from the Western Isles have for understanding the interactions between first farmers and woodlands in the North Atlantic region?

\section{METHODOLOGY}

\section{Field methods}

In 1997, Mr Simon Fraser of Calanais village discovered a possible anthropogenic feature within a coastal peat bank on the edge of East Loch Roag, at Aird Calanais, less than $1 \mathrm{~km}$ from the main Calanais I 


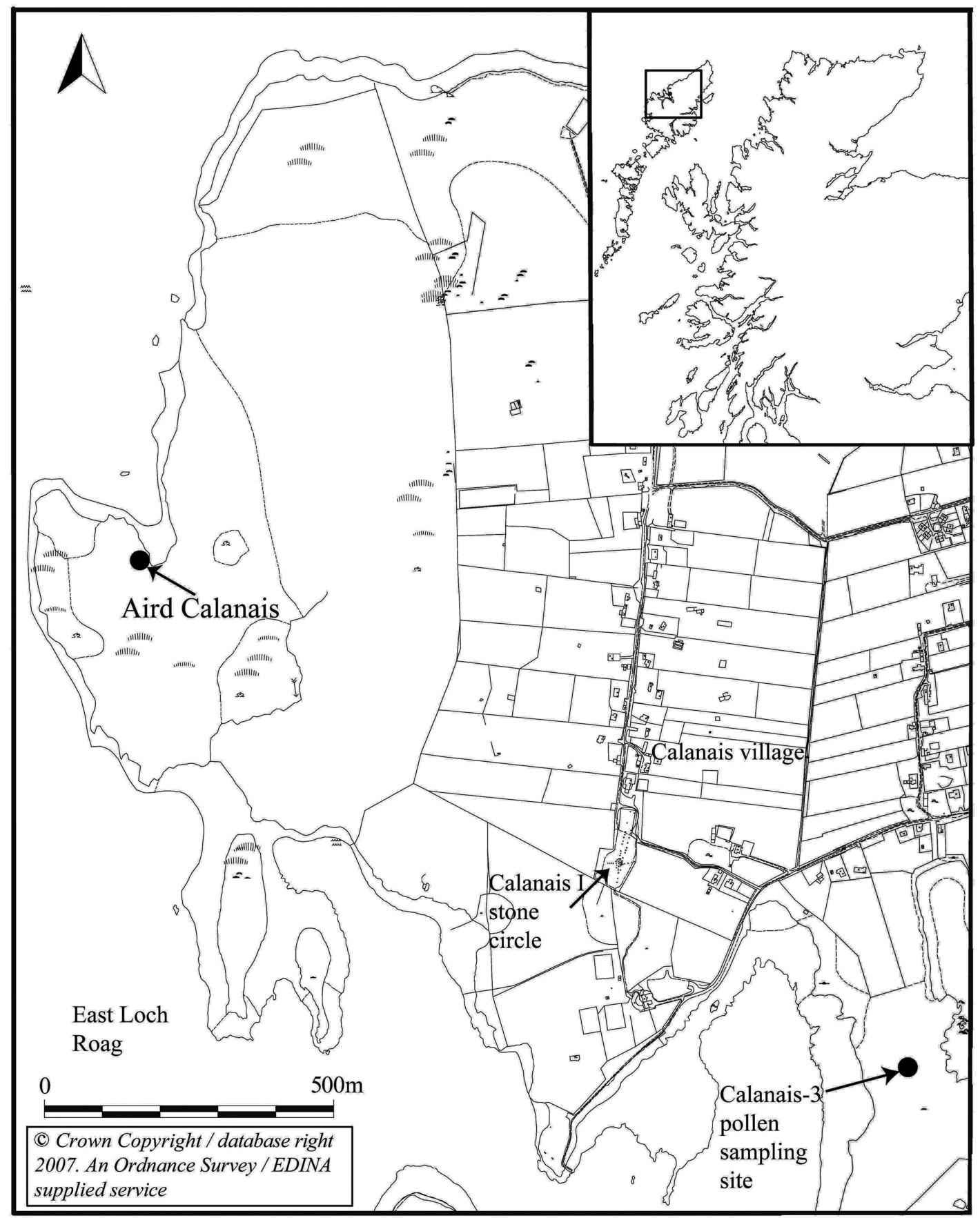

Fig. 1.

Location of the Western Isles \& Aird Calanais, showing the position of the excavation trench in relation to East Loch Roag, the main stone circle site at Calanais I, \& the Calanais-3 pollen sampling site

monument (NGR: NB 206 335; Figs 1-3). The site comprised a charcoal lens enclosed by a semi-circular stone alignment, which was overlain by an extensive wood layer. These features were buried under approximately $1.1 \mathrm{~m}$ of peat and lay directly above a palaeosol. 


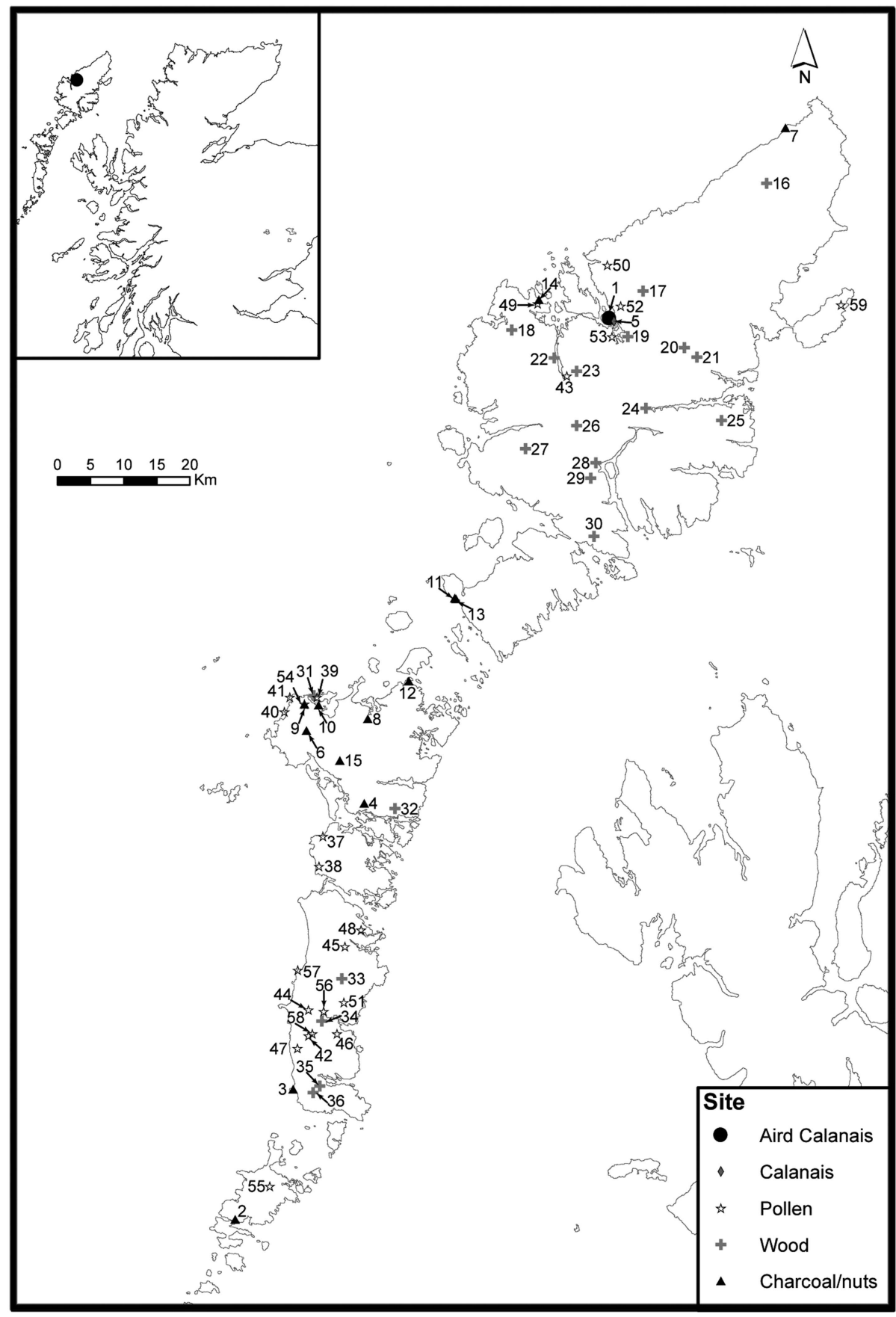

Fig. 2.

Location of pollen, archaeological charcoal/nut \& wood layer sites in the Western Isles in relation to Aird Calanais $\&$ Calanais. Numbers correspond to sites listed in Tables 4-6

The eroding section was cleaned, drawn and photographed prior to excavation, following standard archaeological excavation procedures (Fig. 4). The semi-circular stone alignment extended approximately $0.9 \times 0.6 \mathrm{~m}$ into the section. A $2 \times 1 \mathrm{~m}$ trench was excavated to allow a thorough investigation of this 


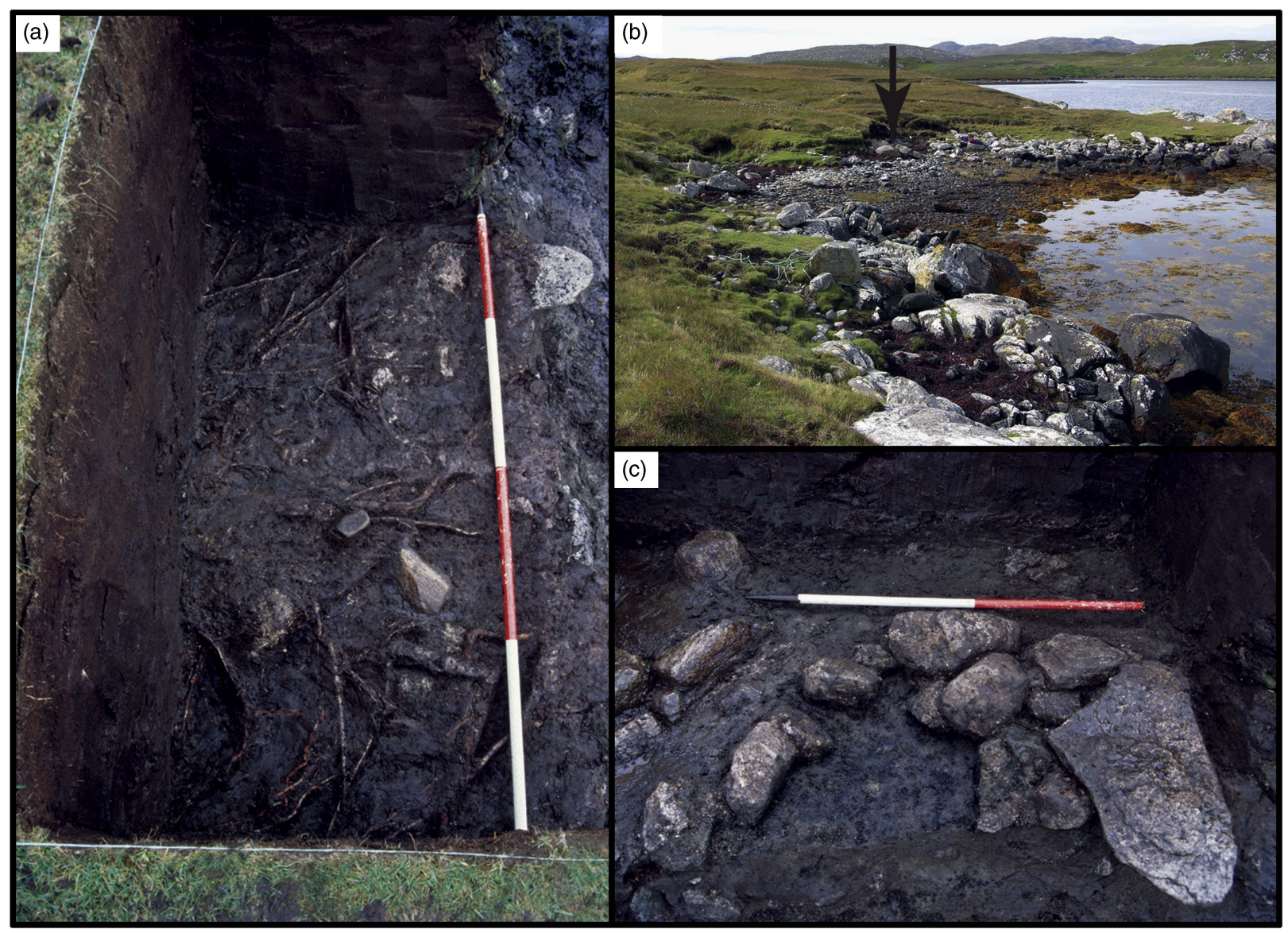

Fig. 3.

(a) The late Neolithic wood layer [3], after the removal of the layer of peat containing occasional twigs [4], from the south; (b) The landscape setting of Aird Calanais in relation to East Loch Roag, from the west. The arrow shows the location of the excavation; (c) the early Neolithic hearth [11], from the south

feature. The wood layer, associated contexts and the charcoal fill of the semi-circular stone alignment were collected in their entirety $(100 \%$ sampling: Jones 1991), and bulk samples were taken from the remaining contexts (total sampling: Jones 1991). A column sample was taken approximately $30 \mathrm{~cm}$ back from the main trench and was stored at $4^{\circ} \mathrm{C}$ prior to laboratory sub-sampling.

\section{Laboratory methods}

A summary of the methodologies employed is provided below. For a full description please see Appendix S1 online.

The stratigraphy and soil colour of the column sample were described (Munsell Color 1975; Rural Development Service 2006), and loss-on-ignition was measured on contiguous $1 \mathrm{~cm}^{3}$ sub-samples at $550^{\circ} \mathrm{C}$ for 4 hours (Heiri et al. 2001). The volume-specific magnetic susceptibility $(\kappa)$ of air-dried and sieved (2 $\mathrm{mm}$ ) sediment was measured using a Bartington MS2G Single Frequency Sensor (Dearing 1994; Bartington Instruments Ltd nd). Following Kenward et al. (1980), $200 \mathrm{ml}$ sub-samples from archaeological contexts 3, 5, and 8 were wet-processed using four sieves $(1 \mathrm{~mm}$ to $125 \mu \mathrm{m})$ to extract uncarbonised palaeo-environmental material. The remaining bulk samples were then processed in the Environmental Archaeology laboratories of Durham University, following Uig Landscape Project archaeobotanical protocols (see Nesbitt et al. 2011, 38-40), using microscopy up to $\times 600$ magnification.

Pollen samples from the column sample were taken from the main stratigraphic phases of the site to assess whether there was a woodland decline contemporary 


\section{Key}

Peaty topsoil and turf [1]

Hagged peat [2]

Wood layer [3] and peat containing occasional twigs [4]

Clay-rich peat containing occasional wood fragments [5]

Dark brown clayey-silt with occasional charcoal flecks (late Mesolithic palaeosol) [6]

Drystone structure (hearth) [7]

Dark brown silty-clay deposit with occasional charcoal flecks (upper hearth fill) [8]

Stone feature [9]

Charcoal layer (early Neolithic hearth fill) [10]

Stone hearth fill [11]

Green-grey boulder clay [12] Brown sandy-silt containing
sand and gravel lenses [13] (a)

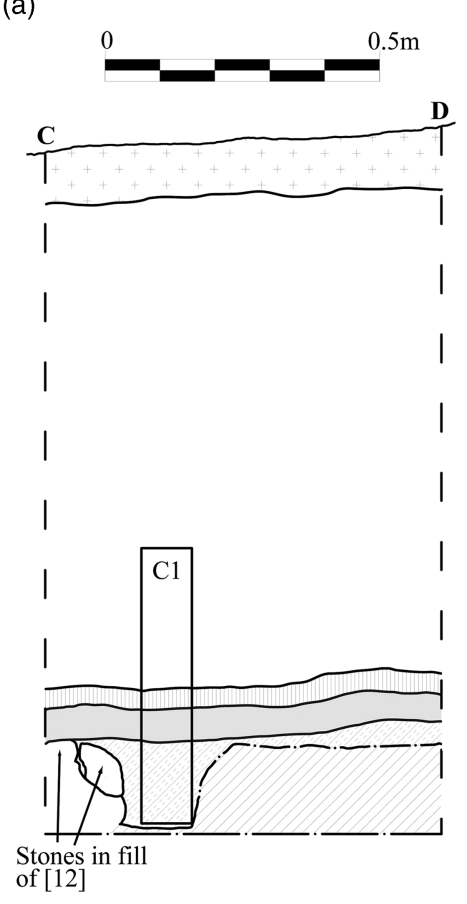

(b)
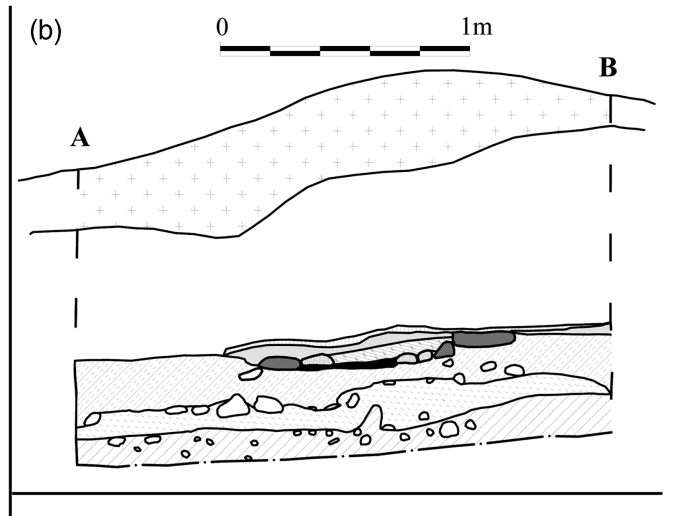

(c)

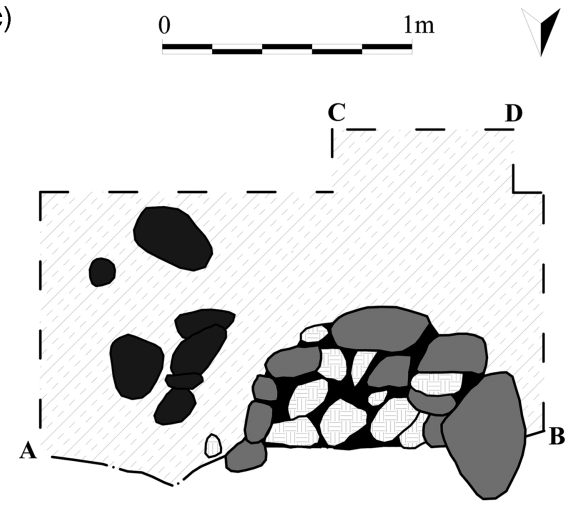

Fig. 4.

Excavation drawings from Aird Calanais: (a) north-facing section, showing column sample location (C1); (b) north-facing section through archaeological features; (c) plan of the late Neolithic hearth prior to excavation, showing position of sections $\mathrm{AB}[(\mathrm{b})] \& \mathrm{CD}[(\mathrm{a})]$

with the archaeological site. The samples were prepared following standard techniques (Moore et al. 1991) and coprophilous fungal spores were also recorded (van Geel et al. 2003). Samples were counted to a minimum of 300 TLP and a maximum of 326 TLP (total land pollen: Rull 1987) at $\times 400$ or $\times 1000$ magnification. Pollen grain damage was recorded following Wilmshurst and McGlone (2005).

Two single-entity plant macrofossils from key archaeological contexts and three $1 \mathrm{~cm}^{3}$ bulk peat samples from the column sample were submitted for AMS radiocarbon dating at the Scottish Universities Environmental Research Centre (Table 1). Dates were calibrated and a Bayesian 'P_Sequence' age-depth model created for the pollen sequence using IntCal13 (Reimer et al. 2013) in OxCal v 4.2.4 (Bronk Ramsey 2009; see below). Due to the mixed nature of the earliest organic soil horizon (archaeological context [6]; see below), the base of the peat (archaeological context [5]) was used as the lowest boundary in this model.

\section{Synthesis of plant macrofossil data}

A database of charred remains from trees and shrubs (charcoal, seeds, fruits, nuts) from Neolithic sites in the Western Isles was compiled by searching through relevant literature, with unpublished reports also obtained from relevant individuals. Radiocarbondated wood layers within peat sequences were synthesised from Bohncke (1988), Fossitt (1996), Rees and Church (2000), and Wilkins (1984).

\section{Synthesis of palynological data}

Palynological evidence from the Western Isles was collated from existing reviews (Church 2006; Edwards et al. 2000) and more recent published sources (see Table 4). Records with significant hiatuses, no data after $6000 \mathrm{cal}$ 
TABLE 1: RADIOCARBON DATES FROM AIRD CALANAIS

\begin{tabular}{|c|c|c|c|c|c|c|c|}
\hline Phase & Context & Sampling location & $\begin{array}{c}\text { Laboratory } \\
\text { code }\end{array}$ & Material & $\begin{array}{c}{ }^{14} \text { C age } \\
{ }_{B P}\end{array}$ & $\begin{array}{c}95.4 \%(2 \pm \sigma) \text { calibrated } \\
\text { age range } B C\end{array}$ & $\begin{array}{l}\delta^{13} \mathrm{C} \\
(\% \circ) \\
\end{array}$ \\
\hline 2 & Palaeosol [6] & $\begin{array}{l}\text { Main excavation } \\
\text { trench }\end{array}$ & SUERC-24887 & $\begin{array}{l}\text { Carbonised Corylus } \\
\text { avellana L. nutshell }\end{array}$ & $6685 \pm 30$ & $5659-5551$ & -25.3 \\
\hline 2 & Palaeosol [6] & & SUERC-24891 & $\begin{array}{l}\text { Carbonised Corylus } \\
\text { avellana L. nutshell }\end{array}$ & $5690 \pm 30$ & 4604-4456 & -23.1 \\
\hline 3 & Lower hearth fill [10] & $\begin{array}{l}\text { Main excavation } \\
\text { trench }\end{array}$ & SUERC-17956 & $\begin{array}{l}\text { Carbonised Betula sp. leaf } \\
\text { bud }\end{array}$ & $4775 \pm 35$ & $3644-3384$ & -26.7 \\
\hline 3 & Lower hearth fill [10] & & SUERC-17957 & $\begin{array}{l}\text { Carbonised Betula sp. leaf } \\
\text { bud }\end{array}$ & $4735 \pm 35$ & $3636-3377$ & -26.3 \\
\hline \multicolumn{8}{|c|}{ Combined age for $[10]: 4755 \pm 27\left(\mathrm{t}\right.$ value $=0.7\left(\chi^{2}: 0.05=3.8\right) 3637-3384 \mathrm{cal} \mathrm{BC}$} \\
\hline 4 & $\begin{array}{l}\text { Clay-rich peat containing occasional } \\
\text { wood fragments [5] }\end{array}$ & $\begin{array}{l}\text { Column sample, } \\
34-35 \mathrm{~cm}\end{array}$ & SUERC-60416 & $\begin{array}{l}\text { Bulk peat: humic fraction } \\
\left(1 \mathrm{~cm}^{3}\right)\end{array}$ & $4377 \pm 28$ & $\begin{array}{c}3090-2911 \\
(* 3082-2922)\end{array}$ & -29.7 \\
\hline 4 & Wood layer [3] & $\begin{array}{l}\text { Main excavation } \\
\text { trench }\end{array}$ & SUERC-24892 & $\begin{array}{l}\text { Uncarbonised } 1 \text { year } \\
\text { Betula sp. twig }\end{array}$ & $4245 \pm 30$ & $2914-2708$ & -29.0 \\
\hline 4 & Wood layer [3] & & SUERC-24893 & $\begin{array}{l}\text { Uncarbonised } 1 \text { year } \\
\text { Betula sp. twig }\end{array}$ & $4300 \pm 30$ & $3011-2880$ & -27.2 \\
\hline \multicolumn{8}{|c|}{ Combined age for [3]: $4273 \pm 22\left(\mathrm{t}\right.$ value $=1.7\left(\chi^{2}: 0.05=3.8\right) 2912-2881 \mathrm{cal} \mathrm{вС}$} \\
\hline 4 & $\begin{array}{l}\text { Wood layer/peat containing occasional } \\
\text { twigs [3/4] }\end{array}$ & $\begin{array}{l}\text { Column sample, } \\
28-29 \mathrm{~cm}\end{array}$ & SUERC-60415 & $\begin{array}{l}\text { Bulk peat: humic fraction } \\
\left(1 \mathrm{~cm}^{3}\right)\end{array}$ & $4284 \pm 28$ & $\begin{array}{c}3003-2876 \\
(* 2916-2878)\end{array}$ & -29.3 \\
\hline 5 & Hagged peat [2] & $\begin{array}{l}\text { Column sample, } \\
24-25 \mathrm{~cm}\end{array}$ & SUERC-60411 & $\begin{array}{l}\text { Bulk peat: humic fraction } \\
\left(1 \mathrm{~cm}^{3}\right)\end{array}$ & $4076 \pm 24$ & $\begin{array}{c}2850-2496 \\
(* 2863-2809)\end{array}$ & -29.7 \\
\hline
\end{tabular}

Combined and calibrated using Oxcal v.4.2.4 (Bronk Ramsey 2009) using Intcal13 (Reimer et al. 2013). The calibrated radiocarbon dates produced using the Oxcal p-sequence age-depth model for the column sample are asterisked $(*)$ and shown in brackets after the unmodelled ranges 
THE PREHISTORIC SOCIETY

TABLE 2: SUMMARY OF THE CONTEXTS, PHASES \& DATES OF THE EXCAVATED HORIZONS AT AIRD CALANAIS

\begin{tabular}{|c|c|c|c|c|c|}
\hline Phase & Context & Dates (cal $B C$ ) & Period & Description & Interpretation \\
\hline 1 & [12] & - & - & Green-grey boulder clay & Natural horizon \\
\hline 1 & [13] & - & - & $\begin{array}{l}\text { Brown sandy-silt containing sand } \\
\text { \& gravel lenses }\end{array}$ & Natural horizon \\
\hline 2 & [6] & $\begin{array}{c}4604- \\
4456 \& \\
5659-5551\end{array}$ & Late Mesolithic & $\begin{array}{l}\text { Dark brown clayey-silt layer } \\
\text { containing occasional charcoal } \\
\text { flecks }\end{array}$ & Palaeosol \\
\hline 3 & [7] & - & Early Neolithic & Drystone structure & Hearth \\
\hline 3 & [10] & $3637-3384$ & Early Neolithic & Charcoal layer & Main (lower) hearth fill \\
\hline 3 & [11] & - & Early Neolithic & Stone deposit & Stone hearth fill \\
\hline 3 & [8] & - & Early Neolithic & $\begin{array}{l}\text { Dark brown silty-clay containing } \\
\text { occasional charcoal flecks }\end{array}$ & Upper hearth fill \\
\hline 3 & [9] & - & Early Neolithic & Irregular linear stone feature & Probable natural stone accumulation \\
\hline 4 & [5] & *3082-2922 & Late Neolithic & $\begin{array}{l}\text { Compact clay-rich peat containing } \\
\text { occasional wood fragments }\end{array}$ & Natural horizon \\
\hline 4 & [3] & 2912-2881 & Late Neolithic & Wood layer & $\begin{array}{l}\text { Naturally formed layer, but wood } \\
\text { probably exploited by Neolithic } \\
\text { people }\end{array}$ \\
\hline 4 & [4] & - & Late Neolithic & $\begin{array}{l}\text { Layer of peat containing occasional } \\
\text { twigs }\end{array}$ & Natural horizon \\
\hline 5 & [2] & $\begin{array}{l}\text { Basal peat: } \\
* 2863-2809\end{array}$ & $\begin{array}{l}\text { Late Neolithic- } \\
\text { Post-medieval }\end{array}$ & Hagged peat & Natural horizon \\
\hline 5 & [1] & - & Post-medieval & Peaty topsoil and turf & Natural horizon \\
\hline
\end{tabular}

Asterisks (*) are used to indicate interpolated rather than raw radiocarbon determinations

$\mathrm{BC}$, or fewer than two reliable radiocarbon dates were excluded. A total of 24 records remained for analysis.

A standardised method was used to identity the timing and amplitude of the decline in tree pollen in the different records and to estimate the date of each woodland decline (for full details see Appendix S1). Following Bronk Ramsey (2008) and Blockley et al. (2008) and using OxCal v4.2.4 (Bronk Ramsey 2009), new Bayesian P_sequence age-depth models were created for each sequence. The calibrated ages of the identified woodland declines were estimated by incorporating the depths of these points within the models. Asterisks (*) are used throughout this paper to indicate interpolated rather than raw radiocarbon determinations.

\section{RESEARCH QUESTION 1: HOW \& WHEN WAS THE ARCHAEOLOGICAL MATERIAL AT AIRD CALANAIS FORMED?}

Five major stratigraphic phases were identified at Aird Calanais (Table 2; Fig. 4). A summary of the results and discussion of the main phases of the site excavation (Phases 2-4) is provided below, with a full description provided in Appendix S2.

Phase 1: the earliest natural horizons

These comprise a green-grey boulder clay [12], overlain by a brown sandy-silt containing sand and gravel lenses [13].

\section{Phase 2: (the late Mesolithic palaeosol)}

This is the earliest organic soil horizon at the site: a very dark-grey clayey-silt containing occasional charcoal flecks [6]. The pollen from this layer (Figs $5 \& 6$ ) was poorly preserved, was relatively poor in arboreal pollen (birch: Betula sp., hazel-type: Corylus-type) and rich in Heather (Calluna vulgaris (L.) Hull), meadowsweets (Filipendula sp.), and fern spores that are typical in early Holocene lake sediment records from the Western Isles (eg, Fossitt 1996). Though the pollen preservation in the uppermost sample from this context was sufficient for vegetation reconstruction, owing to the poor preservation, the pollen data from the three lowest samples are probably not a reliable guide to the palaeovegetation. However, the poor preservation itself is consistent with the interpretation of this context as a palaeosol.

The bulk sample contained just three carbonised hazel (Corylus avellana L.) nutshell fragments and 28 charcoal fragments, which were predominantly willow/poplar (Salicaceae: most likely willow, which is present in the pollen samples), together with some birch (Table 3). Two of the carbonised hazel nutshell fragments produced late Mesolithic dates (5659-5551 cal BC and 4604-4456 cal BC; see Table 1). These single entity dates from short-lived material date precisely 


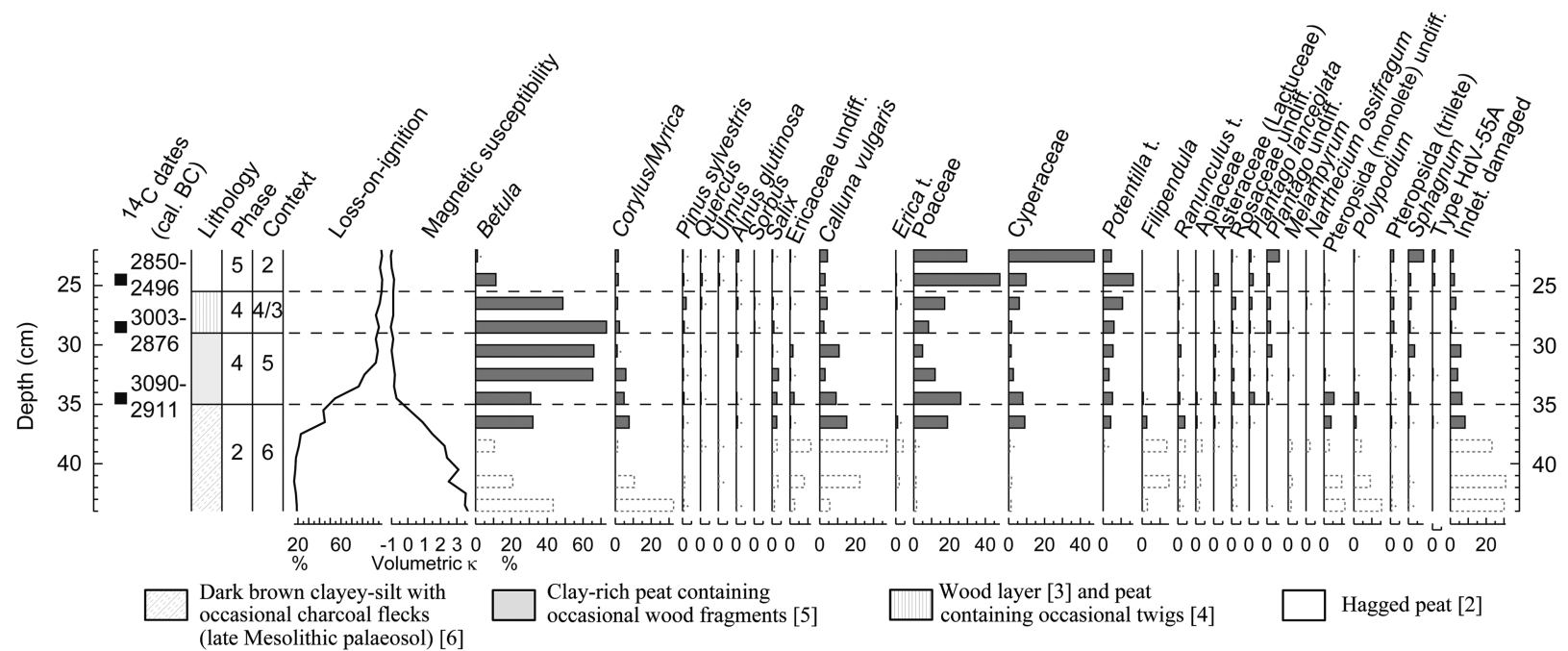

Fig. 5.

Sedimentological \& selected palynological data for the column sample from Aird Calanais. Magnetic susceptibility was recorded as volume-specific $\kappa$. The percentages were calculated as a percentage of total land pollen (TLP). A dot indicates the presence of a taxon at less than $1 \%$. The lowermost three pollen samples are drawn with dashed lines as they are considered to be separate from the main stratigraphic sequence $\&$ were very poorly preserved; see text for details. Rare taxa not shown on this diagram are listed in Table S1 (Criteria: taxa not shown in the diagram are only present in 1-3 samples \& always at $<2 \%$. Sorbus also meets these criteria but remains in the diagram because it is pertinent to the discussion of deforestation). Indet.: Indeterminate pollen (includes degraded/crumpled/concealed \& corroded pollen); t.: type

the year in which the hazelnuts grew. The large interval between them suggests that this soil developed over a long duration.

The arboreal pollen percentages in the uppermost sample from this context are consistent with the possibility that the charcoal and hazelnuts originated in the woodlands around the site (in Scottish peats arboreal pollen typically represents vegetation within c. $300 \mathrm{~m}$ of the site: cf. Bunting 2002; cf. Waller et al. 2005). It is unclear whether they were deposited as a result of human agency or natural processes: no artefacts or archaeological features were found, and it is possible that the nutshell and charcoal were charred in wildfires (cf. Tipping 1996; 2004). However, considering the relatively wet climate in the Western Isles and the rarity of wild fires today, human-made fires are a more convincing explanation for the origin of the charred plant remains (Moore 1996; Ashmore 2016, 982). The charcoal may be fuel waste and the nutshell may have been discarded onto a fire after the kernels had been consumed (Bishop et al. 2014). The horizon may therefore represent one of the very few archaeological sites of Mesolithic date known in the Western Isles (cf. Gregory et al. 2005; Simpson et al. 2006; see Table 5). The burnt remains were probably mixed within the palaeosol by bioturbation, because no discrete burning lenses were identified.

\section{Phase 3: early Neolithic contexts}

Phase 3 represents a coherent, semi-circular stone hearth structure [7] and associated layers [10, 11, 8], which directly overlay the palaeosol [6] (Figs $3 \& 4$ ). The abrupt demarcation between the late Mesolithic palaeosol and the hearth suggests that the early Neolithic soils were eroded in this location. The semicircular structure was constructed of medium-sized angular stones (see Fig. 3c), and although approximately half of it had been eroded prior to excavation, it clearly resembled a hearth. The hearth was filled by a well-preserved charcoal layer [10] - the lower hearth fill - which was dominated by willow/poplar charcoal ( $>50 \%$ of the assemblage), together with birch $(30 \%)$ and hazel (10-20\%) charcoal. Radiocarbon-dated birch leaf buds date the deposit to 3637-3384 cal BC.

Three factors suggest that the hearth represents a single period of use. First, there was no stratigraphic break within the charcoal deposit, suggesting a single burning episode. Secondly, the hearth was of rough construction and could have been made rapidly using 


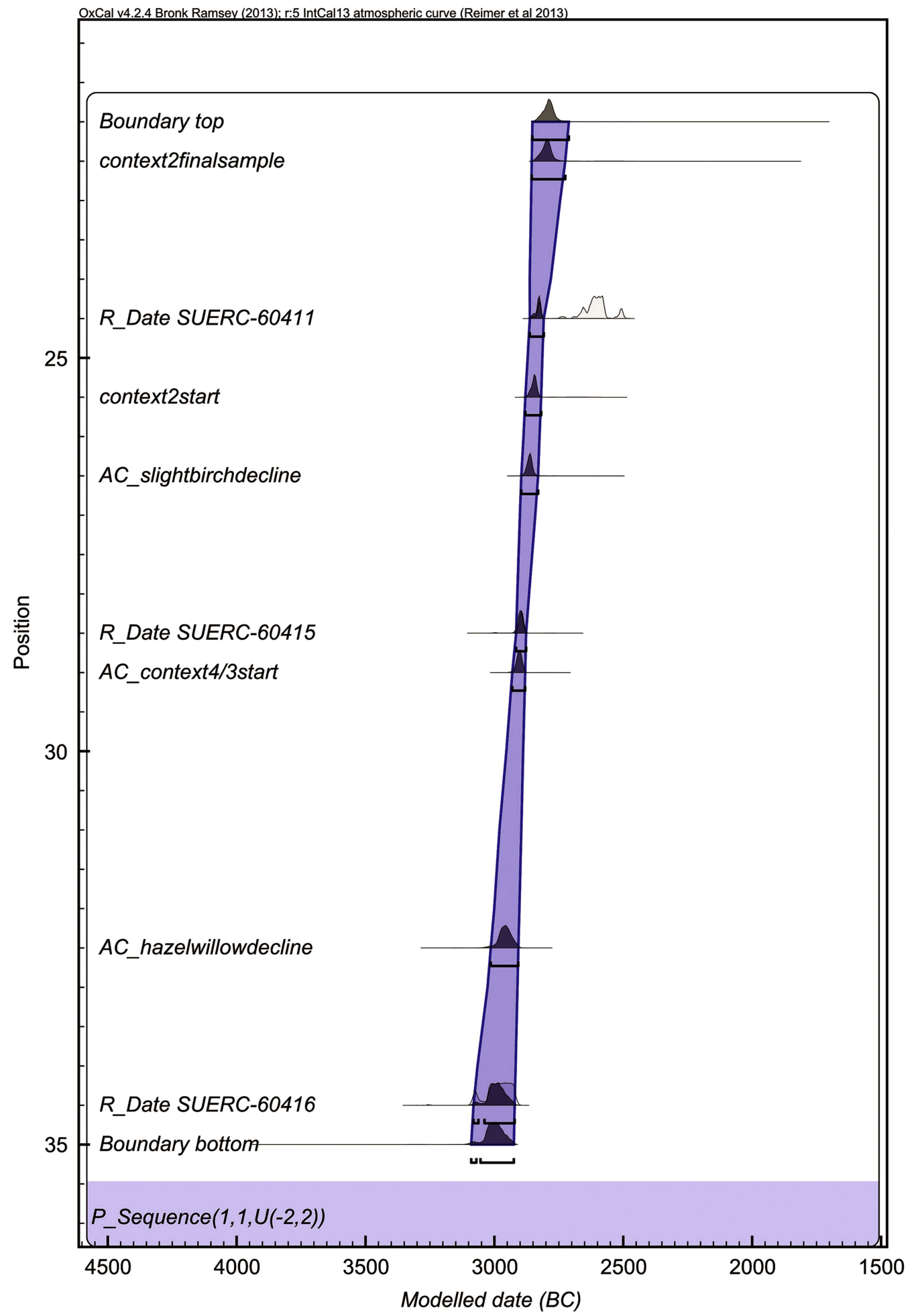

Fig. 6.

Oxcal P_sequence model for the radiocarbon dates from the Aird Calanais column sample, showing the modelled dates for the key features of the pollen curve. The dates were modelled within OxCal v 4.2.4 (Bronk Ramsey 2009) using IntCal13 (Reimer et al. 2013) 


\begin{tabular}{|c|c|c|c|c|c|}
\hline Context & $\begin{array}{c}\text { Late Mesolithic } \\
\text { palaeosol } \\
6\end{array}$ & $\begin{array}{c}\text { Early Neolithic } \\
\text { lower hearth fill } \\
10\end{array}$ & $\begin{array}{c}\text { Early Neolithic } \\
\text { upper hearth fill } \\
8\end{array}$ & $\begin{array}{l}\text { Late Neolithic } \\
\text { compact peat layer } \\
5\end{array}$ & $\begin{array}{c}\text { Late Neolithic } \\
\text { wood layer } \\
3\end{array}$ \\
\hline \multicolumn{6}{|l|}{ BULK SAMPLE RESULTS } \\
\hline Sample volume (l) & 28 & 10 & 3.5 & 7 & 14 \\
\hline \multicolumn{6}{|l|}{ Charcoal } \\
\hline Total charcoal analysed & $29 \mathrm{~F}(1.11 \mathrm{~g})$ & $107 \mathrm{~F}(8.39 \mathrm{~g})$ & $7 \mathrm{~F}(0.29 \mathrm{~g})$ & - & - \\
\hline Sample proportion analysed & $100 \%$ & $12.5 \%$ & $100 \%$ & - & - \\
\hline Betula sp. rw (p to b) & - & $5 \mathrm{~F}$ & - & - & - \\
\hline Betula sp. rw (not $\mathrm{p}$ to $\mathrm{b})$ & $1 \mathrm{~F}$ & $21 \mathrm{~F}$ & $1 \mathrm{~F}$ & - & - \\
\hline Betula sp. $\mathrm{t}$ & $7 \mathrm{~F}$ & $6 \mathrm{~F}$ & - & - & - \\
\hline Corylus sp. rw (p to b) & - & $1 \mathrm{~F}$ & - & - & - \\
\hline Corylus sp. rw (not $\mathrm{p}$ to $\mathrm{b}$ ) & - & $8 \mathrm{~F}$ & - & - & - \\
\hline Corylus sp. $\mathrm{t}$ & - & $9 \mathrm{~F}$ & $2 \mathrm{~F}$ & - & - \\
\hline Salicaceae rw (not $p$ to $b)$ & $2 \mathrm{~F}$ & $37 \mathrm{~F}$ & - & - & - \\
\hline Salicaceae $\mathrm{t}$ & $19 \mathrm{~F}$ & $19 \mathrm{~F}$ & $4 \mathrm{~F}$ & - & - \\
\hline \multirow{2}{*}{\multicolumn{6}{|c|}{ Waterlogged wood }} \\
\hline & & & & & \\
\hline Betula sp. rw (p to b) & - & - & - & $13 \mathrm{~F}$ & $48 \mathrm{~F}$ \\
\hline Betula sp. rw (not $\mathrm{p}$ to $\mathrm{b})$ & - & - & - & $1 \mathrm{~F}$ & $1 \mathrm{~F}$ \\
\hline Betula sp. rw/t/rt & - & - & - & $1 \mathrm{~F}$ & - \\
\hline cf. Betula sp. rw (p to b) & - & - & - & $35 \mathrm{~F}$ & $173 \mathrm{~F}$ \\
\hline cf. Betula sp. rw (not p to b) & - & - & - & - & $16 \mathrm{~F}$ \\
\hline cf. Betula sp. rt & - & - & - & - & $1 \mathrm{~F}$ \\
\hline cf. Betula sp. rw/t/rt & - & - & - & - & $1 \mathrm{~F}$ \\
\hline Indeterminate & - & - & - & $10 \mathrm{~F}$ & - \\
\hline \multicolumn{6}{|l|}{$\begin{array}{l}\text { Carbonised plant } \\
\text { macrofossils }\end{array}$} \\
\hline Corylus avellana L. (nt) & $3 \mathrm{~F}$ & - & - & - & - \\
\hline Indeterminate seed & - & - & 1 & - & - \\
\hline \multicolumn{6}{|c|}{ WET-PROCESSED SAMPLE RESULTS } \\
\hline Sample volume (ml) & - & - & 200 & 200 & 200 \\
\hline \multicolumn{6}{|l|}{ Uncarbonised remains } \\
\hline Carex sp. biconvex (n) & - & - & - & 82 & 152 \\
\hline Carex sp. trigonous $(\mathrm{n})$ & - & - & - & 1 & - \\
\hline Juncus cf. effusus L. (s) & - & - & $100^{*}$ & $1380 *$ & $3500 *$ \\
\hline Potentilla sp. (a) & - & - & 2 & 26 & 96 \\
\hline Viola sp. (s) & - & - & - & 26 & 10 \\
\hline Acari (Mites) & - & - & - & - & c \\
\hline Cenococcum geophilum (fs) & - & - & b & $\mathrm{d}$ & e \\
\hline Cladocera (Water fleas) & - & - & - & - & d \\
\hline
\end{tabular}

F: fragment; nt: nutshell fragment; n: nutlet; a: achene; c: caryopsis; s: seed; fs: fungal sclerotia; rw: roundwood; rt: rootwood; t: timber; (not $p$ to b): not pith to bark; $(p$ to b): pith to bark. Numbers refer to total counts and letters $(a=e)$ to relative abundance on a scale from a (lowest) to e (highest). Remains from the wet-processed samples are shown as total counts $/ 200 \mathrm{ml}$ or relative abundance/200 $\mathrm{ml}$. *: counts estimated using a sub-sample

stone gathered from the immediate vicinity. There was no evidence of hearth slabs or cutting to create a stable surface for repeated use. This is very different to the multiple-use hearths on Neolithic domestic sites in Atlantic Scotland, which are normally carefully constructed using large stone slabs (eg, Scott 1950; Ritchie 1983; Crone 1993a; Branigan \& Foster 1995; Mills et al. 2004; Thomas \& Lee 2012). Thirdly, edible plant remains and turf/peat fuel remnants (eg, carbonised seeds from heathy plants) which are usually recovered from Neolithic settlements in the region (Church et al. 2007b; Bishop et al. 2009) were absent. Instead, native deciduous branches and timber were used as fuel in the hearth. Therefore, the hearth appears to have been a single-use fire, deriving from the opportunistic gathering of wood from the local environment. 
THE PREHISTORIC SOCIETY

TABLE 4: DESCRIPTION OF THE POLLEN SITES INCLUDED IN THE WOODLAND DECLINE EVENT MODELS

\begin{tabular}{|c|c|c|c|c|c|c|c|}
\hline Site & $\begin{array}{l}\text { Site } \\
\text { no. }\end{array}$ & Location & $\begin{array}{c}\text { Coastal/ } \\
\text { inland/ } \\
\text { intertidal }\end{array}$ & Site type & $\begin{array}{l}\text { No. radio- } \\
\text { carbon dates }\end{array}$ & $\begin{array}{c}\text { Radiocarbon sample } \\
\text { type }\end{array}$ & Reference \\
\hline Aird Calanais & 1 & Lewis & Inland & Peat deposit & 3 & $\begin{array}{l}\text { Bulk peat: humic } \\
\text { fraction }(1 \mathrm{~cm} \text { slices })\end{array}$ & This paper \\
\hline An Ceòthon & 37 & Benbecula & Intertidal & $\begin{array}{l}\text { Organic } \\
\text { deposit }\end{array}$ & 2 & $\begin{array}{l}\text { Bulk sediment/ peat } \\
(0.3 \mathrm{~cm})\end{array}$ & Ritchie et al. 2000 \\
\hline Borve 3 & 38 & Benbecula & Intertidal & $\begin{array}{l}\text { Organic } \\
\text { deposit }\end{array}$ & 8 & $\begin{array}{l}7 \times \text { pollen }+1 \times \\
\text { Phragmites leaves }\end{array}$ & Edwards et al. 2005b \\
\hline Calanais & 5 & Lewis & Inland & Peat deposit & $\begin{array}{c}9 \\
(+2 \text { removed })\end{array}$ & $\begin{array}{l}\text { Bulk sediment } / \text { peat } \\
(8 \times 1-2 \mathrm{~cm}+ \\
1 \times 7 \mathrm{~cm} \text { slices })\end{array}$ & $\begin{array}{l}\text { Bohncke 1988; } \\
\text { Bohncke et al. } 2016\end{array}$ \\
\hline Camas Mór & 39 & $\begin{array}{l}\text { North } \\
\text { Uist }\end{array}$ & Intertidal & $\begin{array}{l}\text { Organic } \\
\text { deposit }\end{array}$ & 4 & $\begin{array}{l}\text { Bulk sediment/ peat } \\
(0.4 \mathrm{~cm} \text { slices })\end{array}$ & Ritchie et al. 2000 \\
\hline Cladach Mór & 40 & $\begin{array}{l}\text { North } \\
\text { Uist }\end{array}$ & Intertidal & $\begin{array}{l}\text { Organic } \\
\text { deposit }\end{array}$ & 2 & $\begin{array}{l}\text { Bulk sediment/ peat } \\
(0.1 \& 1 \mathrm{~cm} \text { slices })\end{array}$ & Ritchie et al. 2000 \\
\hline Fiarigeo & 41 & $\begin{array}{r}\text { North } \\
\text { Uist }\end{array}$ & Coastal & $\begin{array}{l}\text { Organic } \\
\text { deposit }\end{array}$ & 2 & $\begin{array}{l}\text { Bulk sediment/ peat } \\
(0.5 \mathrm{~cm} \text { slices })\end{array}$ & Ritchie et al. 2000 \\
\hline Frobost & 42 & $\begin{array}{l}\text { South } \\
\text { Uist }\end{array}$ & Inland & Valley mire & 3 & $\begin{array}{l}\text { Bulk sediment/ peat } \\
(5-10 \mathrm{~cm} \text { slices })\end{array}$ & Mulder 1999 \\
\hline Little Loch Roag & 43 & Lewis & Inland & Mire & 6 & $\begin{array}{l}\text { Bulk sediment/ peat } \\
\text { ( } 5 \mathrm{~cm} \text { slices })\end{array}$ & Birks \& Madsen 1979 \\
\hline Loch a' Chabhain & 44 & $\begin{array}{l}\text { South } \\
\text { Uist }\end{array}$ & Inland & Loch & 5 & $\begin{array}{l}\text { Bulk sediment/ peat } \\
(5-10 \mathrm{~cm} \text { slices })\end{array}$ & Mulder 1999 \\
\hline $\begin{array}{l}\text { Loch Airigh na } \\
\text { h-Achlais }\end{array}$ & 45 & $\begin{array}{l}\text { South } \\
\text { Uist }\end{array}$ & Inland & Loch & 5 & $\begin{array}{l}\text { Bulk sediment/ peat } \\
\quad(5-10 \mathrm{~cm} \text { slices })\end{array}$ & Mulder 1999 \\
\hline $\begin{array}{l}\text { Loch Airigh na } \\
\text { h-Aon Oidhche }\end{array}$ & 46 & $\begin{array}{l}\text { South } \\
\text { Uist }\end{array}$ & Inland & Loch & 4 & $\begin{array}{l}\text { Bulk sediment/ peat } \\
\quad(5-10 \mathrm{~cm} \text { slices })\end{array}$ & $\begin{array}{l}\text { Edwards unpubl. data; } \\
\text { Edwards et al. 1995; } \\
2000\end{array}$ \\
\hline Loch an t-sil & 47 & $\begin{array}{l}\text { South } \\
\text { Uist }\end{array}$ & Inland & $\begin{array}{l}\text { Infilled } \\
\text { kettle hole }\end{array}$ & $\begin{array}{c}4 \\
\text { (+ } 1 \text { removed })\end{array}$ & $\begin{array}{l}\text { Bulk sediment/ peat } \\
(5-10 \mathrm{~cm} \text { slices })\end{array}$ & $\begin{array}{l}\text { Edwards unpubl. data; } \\
\text { Edwards et al. 1995; } \\
2000\end{array}$ \\
\hline Loch a' Phuinnd & 48 & $\begin{array}{l}\text { South } \\
\text { Uist }\end{array}$ & Inland & Loch & 5 & $\begin{array}{l}\text { Bulk sediment/ peat } \\
\text { (8-10 cm slices })\end{array}$ & Fossitt 1996 \\
\hline Loch Bharabhat & 49 & Lewis & Inland & Loch & $\begin{array}{c}8 \\
(+1 \text { removed })\end{array}$ & $\begin{array}{l}\text { Bulk sediment/ peat } \\
\text { (10 cm slices })\end{array}$ & Lomax 1997 \\
\hline $\begin{array}{l}\text { Loch Buailaval } \\
\text { Beag }\end{array}$ & 50 & Lewis & Inland & Loch & 5 & $\begin{array}{l}\text { Bulk sediment/ peat } \\
\text { (8-11 cm slices })\end{array}$ & Fossitt 1996 \\
\hline Loch Lang & 51 & $\begin{array}{l}\text { South } \\
\text { Uist }\end{array}$ & Inland & Loch & 6 & $\begin{array}{l}\text { Bulk sediment/ peat } \\
(6-10 \mathrm{~cm} \text { slices })\end{array}$ & Bennett et al. 1990 \\
\hline $\begin{array}{l}\text { Loch na Beinne } \\
\text { Bige }\end{array}$ & 52 & Lewis & Inland & Loch & 6 & $\begin{array}{l}\text { Bulk sediment/ peat } \\
(10 \mathrm{~cm} \text { slices })\end{array}$ & Lomax 1997 \\
\hline Loch na Muilne & 53 & Lewis & Inland & Loch & 3 & $\begin{array}{l}\text { Bulk sediment/ peat } \\
\text { (10 cm slices })\end{array}$ & Lomax 1997 \\
\hline Loch Olabhat & 54 & $\begin{array}{r}\text { North } \\
\text { Uist }\end{array}$ & Inland & Loch & 7 & $\begin{array}{l}\text { Bulk sediment/ peat } \\
\text { ( } 1 \mathrm{~cm} \text { slices })\end{array}$ & $\begin{array}{l}\text { Mulder 1999; } \\
\text { Edwards et al. } 2000\end{array}$ \\
\hline $\begin{array}{l}\text { Lochan na } \\
\text { Cartach }\end{array}$ & 55 & Barra & Inland & Loch & $\begin{array}{c}5 \\
(+3 \text { removed })\end{array}$ & $\begin{array}{l}\text { Bulk sediment/ peat } \\
\quad(2-3 \mathrm{~cm} \text { slices })\end{array}$ & $\begin{array}{l}\text { Brayshay \& Edwards } \\
\text { 1996; Brayshay } \\
1992\end{array}$ \\
\hline $\begin{array}{l}\text { North } \\
\text { Locheynort }\end{array}$ & 56 & $\begin{array}{l}\text { South } \\
\text { Uist }\end{array}$ & Coastal & Loch & 3 & $\begin{array}{l}\text { Bulk sediment/ peat } \\
\quad(10 \mathrm{~cm} \text { slices })\end{array}$ & $\begin{array}{l}\text { Brayshay \& Edwards } \\
\text { 1996; Edwards } \\
\text { unpubl. data }\end{array}$ \\
\hline Peninerine & 57 & $\begin{array}{r}\text { South } \\
\text { Uist }\end{array}$ & Intertidal & $\begin{array}{l}\text { Organic } \\
\text { deposit }\end{array}$ & 4 & $\begin{array}{l}\text { Bulk sediment/ peat } \\
(0.4-0.5 \mathrm{~cm} \text { slices })\end{array}$ & Ritchie et al. 2000 \\
\hline
\end{tabular}




\section{R.R. Bishop et al. DEFORESTATION \& HUMAN AGENCY, WESTERN ISLES OF SCOTLAND}

TABLE 4: (Continued)

\begin{tabular}{|c|c|c|c|c|c|c|c|}
\hline Site & $\begin{array}{l}\text { Site } \\
\text { no. }\end{array}$ & Location & $\begin{array}{l}\text { Coastal/ } \\
\text { inland/ } \\
\text { intertidal }\end{array}$ & Site type & $\begin{array}{l}\text { No. radio- } \\
\text { carbon dates }\end{array}$ & $\begin{array}{c}\text { Radiocarbon sample } \\
\text { type }\end{array}$ & Reference \\
\hline Reineval & 58 & $\begin{array}{r}\text { South } \\
\text { Uist }\end{array}$ & Inland & Lochan & 4 & $\begin{array}{l}\text { Bulk sediment/ peat } \\
(5-12 \mathrm{~cm} \text { slices })\end{array}$ & $\begin{array}{l}\text { Edwards unpubl. data; } \\
\text { Edwards et al. 1995; } \\
2000\end{array}$ \\
\hline Sheshader & 59 & Lewis & Inland & Peat deposit & 4 & $\begin{array}{l}\text { Bulk sediment/ peat } \\
(1-2.5 \mathrm{~cm} \text { slices })\end{array}$ & Newell 1988 \\
\hline
\end{tabular}

With the exception of Loch an t-sil (which had one radiocarbon date excluded because it produced an agreement index $<60 \%$ ), the radiocarbon dates removed were excluded because they were not included in the original models by the authors (references listed in the table). Site numbers refer to those in Fig. 2

The willow-dominated firewood collected and burnt at Aird Calanais differs from the general fuel procurement strategy across the Western Isles, which is predominantly birch or hazel firewood (see Table 5; Fig. 7). This probably reflects its unusual nature as a single-use hearth relating to a specific activity, whereas the other assemblages are from settlements or monuments, so derive from longerterm use and a greater range of activities. Unfortunately, the fragmented nature of the charcoal assemblage (only six fragments had complete transverse sections from pith to bark) precludes a more detailed examination of the wood selection (eg, diameter selection) or woodland management strategies (eg, coppicing: cf. Out et al. 2013) that may have been occurring at Aird Calanais.

The stone layer [11] and upper hearth fill [8] may represent deliberate anthropogenic deposits, perhaps to cover the fire at the end of its use. The sedimentology and archaeobotanical species composition of the upper hearth fill [8] (Table 3) were similar to those of the late Mesolithic palaeosol [6], and the charcoal fragments were abraded, perhaps due to redeposition. This suggests that the upper hearth fill may have been deliberately extracted from the palaeosol to dampen down the fire at the end of its use.

\section{Phase 4: late Neolithic contexts}

Phase 4 is interpreted as the remains of a phase of major woodland decline. Immediately above the hearth was a layer of compact clay-rich peat containing occasional wood fragments [5], overlain by a distinct layer of intact twigs and bark [3] (Fig. 3a). Both the wood layer [3] and compact peat [5] contained birch roundwood (Table 3), which was of a small diameter $(2-44 \mathrm{~mm})$ and young age (1-10 years; Fig. 8). The combined date of two 1 -year old birch twigs from the wood layer [3] was 2912-2881 cal вС (late Neolithic).

The late Neolithic wood layer [3] covered most of the trench, with the exception of the eastern side of the eroded edge of section $\mathrm{A}-\mathrm{B}$, and extended into the trench edges (Figs $3 \& 4$ ). The abundance of the wood varied across the excavated horizon, from dense concentrations to more sparsely scattered twigs. The wood layer [3] was overlain by a thin layer of peat containing occasional twigs [4]. Throughout most of the trench, [3] and [4] were visible as distinct layers, but where [3] was relatively thin, for example in the column sample, the boundary between these contexts was indistinct and they were recorded as [4/3].

Two factors suggest that the wood layer [3] was formed during the main period of woodland decline at the site. First, [3] extended beyond the excavated area and appears to have been composed entirely of birch, which the pollen evidence from the column shows was the main taxa in the woodland surrounding the site at the time the wood layer formed (Fig. 5). At the base of the late Neolithic wood layer (*2916-2878 cal BC), birch was as high as $73 \%$, with smaller quantities of hazeltype (Corylus-type), willow (Salix sp.), and other tree/ shrub taxa also present, and heather moderately abundant. Secondly, the wood layer was contemporary with a decline in birch in the on-site pollen record, which suggests that the extent of birch woodland was reduced after the wood layer had been deposited. Arboreal pollen declined rapidly in the late Neolithic from $78 \%$ at the base of the late Neolithic wood layer ([4/3], phase 4: *2931-2881 cal BC) to $16 \%$ at the base of the hagged peat ([2], phase 5: *2863-2809 cal BC), and finally to $5 \%$ at the top of the analysed pollen sequence $(* 2856-$ 2726 cal BC) (Fig. 5). 
Several factors suggest that the layer was not an anthropogenic deposit of wood. The wood was preserved in wet conditions and there was no evidence for burning. The absence of timber fragments (Table 3) or shaped or cut roundwood (cf. Boyd 1988, 613) and the lack of coherent structural arrangement of the wood, together with the lack of artefacts or archaeological features shows that this layer did not form part of a structure, such as a collapsed roof, floor, or trackway. Thus, the horizon appears to contain a natural accumulation of wood that was fortuitously preserved in waterlogged conditions.

The similarity of the layer to other peat deposits containing birch remains on Lewis (Wilkins 1984) supports this conclusion. Wilkins (ibid., 254) notes that the birch branches, 'were usually found in a horizontal layer near the bottom of the peat ... The material gave a distinct impression of fallen branches which had become buried rather than roots in situ in the peat ... In some cases the layer was very dense and the most recent episode of peat cutting had exposed an extensive platform of tangled wood'.

Wilkins observed no stumps of birch. The absence of birch stumps in Lewisian peats suggests that peat formation was not directly responsible for the death of the birch trees at these sites, but rather, birch branches from trees growing close to the peat were deposited and subsequently preserved within it. Pine (Pinus sp.), by contrast, is represented in Neolithic peats on Lewis predominantly by stumps. It appears to have directly colonised the peat, most likely during more favourable drier bog-surface conditions, before being preserved as the bog accumulated (Edvardsson et al. 2012).

There is evidence that climatic deterioration played an important role in woodland decline at Aird Calanais. Peat had already begun to accumulate prior to the formation of the wood layer and the preservation of the wood and water fleas (Cladocera; Duigan \& Birks 2000) within this layer indicates the development of areas of standing water, which could have increased the mortality of standing trees and inhibited the recruitment of new tree/shrub seedlings (Wilkins 1984, 256). A gradual increase in grass (Poaceae) and sedge (Cyperaceae) pollen at the expense of buttercup (Ranunculus sp.), Carrot family (Apiaceae), and ferns, and the macrofossil record of increasing abundance of rush (Juncus sp.) seeds (Table 3), suggests a gradual expansion of wet acid heath and peat. Increased precipitation is documented from other proxy records elsewhere in Northern Scotland for the period c. 3100-2400 cal вс (Tipping \& Tisdall 2004, 74-6). As well as potentially killing or preventing the recolonisation of the trees in waterlogged areas, an increase in wetness would have improved conditions for the preservation of birch branches within the peat (Fossitt 1996, 193).

However, it is not possible to exclude the involvement of people in the formation of this deposit at Aird Calanais. First, whilst there was no evidence for cut marks on the branches examined, it is possible that people felled the tree trunks on which the branches grew. Secondly, the ring curvature and age and diameter profiles of the wood from the horizon shows that it is neither the remains of a single birch shrub, nor is it a random selection of birch branches from the local woodland: there were no timber fragments (ie, remains from medium and large diameter branches and trunks) or definite rootwood fragments (Table 3). The branch age and size data was not normally distributed. The size/age ranges of the branches are tightly clustered with no branches over 10 years old or greater than $45 \mathrm{~mm}$ in diameter (Fig. 8). The wood remains were primarily less than $2 \mathrm{~cm}$ in diameter, so it is not possible to identify if the assemblage was derived from managed woodlands (eg, by coppicing; Out et al. 2013). However, the absence of larger ( $>45 \mathrm{~mm}$ diameter) and older branches ( $>10$ years) could suggest that people selectively removed these branches, perhaps for construction purposes, as suggested by the archaeobotanical evidence from other sites in the region. At Eilean Domnuill, for instance, the uncarbonised birch roundwood remains (mostly structural post/stake remains) were predominantly greater than $40 \mathrm{~mm}$ in diameter, whereas the charcoal (representing firewood remnants) from Eilean Domnuill, Bharpa Carinish, and Calanais, mostly consisted of small branches of less than $40 \mathrm{~mm}$ diameter (Fig. 9a-b; Crone 1993b; 2000).

Overall, the evidence suggests that the wood layer at Aird Calanais was probably a natural layer of branches that was deposited as a result of woodland decline around the site. The wood layer may have been exploited by Neolithic people, perhaps as a source of construction materials.

\section{Phase 5: most recent deposits}

These comprise the hagged peat [2] and the peaty topsoil and turf [1]. The peat reached a depth of $105 \mathrm{~cm}$ and immediately overlay the wood layer [3]. 
R.R. Bishop et al. DEFORESTATION \& HUMAN AGENCY, WESTERN ISLES OF SCOTLAND

TABLE 5: CHARRED ARCHAEOBOTANICAL REMAINS FROM TREES \& SHRUBS RECOVERED FROM MESOLITHIC \& NEOLITHIC SITES IN THE WESTERN ISLES OF SCOTLAND

\begin{tabular}{|c|c|c|c|c|c|c|c|c|c|}
\hline Site & $\begin{array}{c}\text { Site } \\
\text { number }\end{array}$ & Location & $\begin{array}{l}\text { Site } \\
\text { type }\end{array}$ & $\begin{array}{l}\text { Date range } \\
\text { (cal } \mathrm{BC})\end{array}$ & $\begin{array}{c}\text { Alder } \\
\text { (Alnus sp.) }\end{array}$ & $\begin{array}{c}\text { Ash } \\
\text { (Fraxinus } \\
\text { sp.) }\end{array}$ & $\begin{array}{c}\text { Birch } \\
\text { (Betula } s p .)\end{array}$ & $\begin{array}{c}\text { Crab Apple } \\
\text { (Malus sylvestris } \\
\text { (L.) Mill.) }\end{array}$ & $\begin{array}{c}\text { Crab Apple/Pear/ } \\
\text { Whitebeam/ Rowan/Hawthorn/ } \\
\text { Wild Service (Rosaceae: } \\
\text { Pomoideae/ } \\
\text { Maloideae/ Sorbus sp.) }\end{array}$ \\
\hline \multicolumn{10}{|l|}{ Mesolithic } \\
\hline Aird Calanais & 1 & Lewis & $\mathrm{S}$ & $5659-4456$ & - & - & $\begin{array}{c}8 \mathrm{~F} \\
(0.2 \mathrm{~g})\end{array}$ & - & - \\
\hline Northton & 11 & Harris & $S$ & $7051-6104$ & - & - & - & - & - \\
\hline Temple Bay & 13 & Harris & $\mathrm{S}$ & $5715-5386$ & - & - & - & - & - \\
\hline $\begin{array}{l}\text { Tràigh na } \\
\text { Beirigh }\end{array}$ & 14 & Lewis & $\mathrm{S}$ & 4341-3994 & - & - & - & - & - \\
\hline $\begin{array}{l}\text { Tràigh na } \\
\text { Beirigh } 2\end{array}$ & 14 & Lewis & $\mathrm{S}$ & $4668-4401$ & - & - & - & - & - \\
\hline $\begin{array}{l}\text { Tràigh na } \\
\text { Beirigh } 9\end{array}$ & 14 & Lewis & $\mathrm{S}$ & $4330-4044$ & - & - & - & - & - \\
\hline Pabaigh Mòr & 14 & Lewis & $\mathrm{S}$ & $7166-4449$ & - & - & - & - & - \\
\hline \multicolumn{10}{|l|}{ Neolithic } \\
\hline Aird Calanais & 1 & Lewis & $\mathrm{S}$ & $3637-3384$ & - & - & $\begin{array}{c}34 \mathrm{~F} \\
(3.1 \mathrm{~g})\end{array}$ & - & - \\
\hline Allt Chrisal & 2 & Barra & $\mathrm{S}$ & $3711-2934$ & $\begin{array}{c}94 \mathrm{~F} \\
(3.6 \mathrm{~g})\end{array}$ & - & $\begin{array}{c}603 \mathrm{~F} \\
(33.8 \mathrm{~g})\end{array}$ & - & $\begin{array}{c}51 \mathrm{~F} \\
(1.9 \mathrm{~g})\end{array}$ \\
\hline An Doirlinn & 3 & $\begin{array}{c}\text { South } \\
\text { Uist }\end{array}$ & $\mathrm{S}$ & $3446-2127$ & $10 \mathrm{~F}$ & $11 \mathrm{~F}$ & $5 \mathrm{~F}$ & - & $1 \mathrm{~F}$ \\
\hline Bharpa Carinish & 4 & $\begin{array}{l}\text { North } \\
\text { Uist }\end{array}$ & $\mathrm{S}$ & $3366-2505$ & - & - & $46 \mathrm{~F}$ & $+s$ & $3 \mathrm{~F}$ \\
\hline Calanais & 5 & Lewis & $\begin{array}{l}\text { SC, } \\
\text { CC }\end{array}$ & $5341-1693 *$ & $75 \mathrm{~F}$ & - & $107 \mathrm{~F}$ & - & $16 \mathrm{~F}$ \\
\hline Clettraval & 6 & $\begin{array}{l}\text { North } \\
\text { Uist }\end{array}$ & $\mathrm{CC}$ & c. $4000-2500$ & - & - & $\mathrm{P}$ & - & - \\
\hline Dunasbroc & 7 & Lewis & $\mathrm{S}$ & $3661-3104$ & - & - & $\mathrm{P}$ & - & - \\
\hline Eilean an Tighne & 8 & $\begin{array}{l}\text { North } \\
\text { Uist }\end{array}$ & $\mathrm{S}$ & c. $4000-2500$ & - & - & A & - & - \\
\hline $\begin{array}{l}\text { Eilean } \\
\text { Domhnuill }\end{array}$ & 9 & $\begin{array}{l}\text { North } \\
\text { Uist }\end{array}$ & $S$ & $3792-2356$ & $9 \mathrm{~F}$ & - & $152 \mathrm{~F}$ & - & - \\
\hline Geirisclett & 10 & $\begin{array}{l}\text { North } \\
\text { Uist }\end{array}$ & $\mathrm{CC}$ & c. $4000-2500$ & - & - & $2.77 \mathrm{~g}$ & - & - \\
\hline Screvan Quarry & 12 & $\begin{array}{c}\text { North } \\
\text { Uist }\end{array}$ & S & $3515-2491$ & - & - & $392 \mathrm{~F}$ & - & - \\
\hline Unival & 15 & $\begin{array}{l}\text { North } \\
\text { Uist }\end{array}$ & $\mathrm{CC}$ & c. $4000-2500$ & - & - & $\mathrm{P}$ & - & - \\
\hline
\end{tabular}




\begin{tabular}{|c|c|c|c|c|c|c|c|c|c|c|c|c|}
\hline $\begin{array}{l}\text { Cherry/ } \\
\text { Blackthorn } \\
\text { (Prunus sp.) }\end{array}$ & $\begin{array}{l}\text { Hazel } \\
\text { (Corylus } \\
s p .)\end{array}$ & $\begin{array}{l}\text { Heather } \\
\text { (Calluna } \\
\text { vulgaris } \\
\text { (L.) Hull.) }\end{array}$ & $\begin{array}{l}\text { Oak } \\
\text { (Quercus } \\
s p . \text { ) }\end{array}$ & $\begin{array}{l}\text { Willow } \\
\text { (Salix sp.) }\end{array}$ & $\begin{array}{l}\text { Willow/ } \\
\text { Poplar/ } \\
\text { Willow } \\
\text { family } \\
\text { (Salicaceae) } \\
\end{array}$ & $\begin{array}{l}\text { Larch/ } \\
\text { Spruce } \\
\text { (Picea/ } \\
\text { Larix sp.) }\end{array}$ & $\begin{array}{l}\text { Pine (Pinus } \\
\text { sp.) }\end{array}$ & $\begin{array}{l}\text { Yew } \\
\text { (Taxus } \\
s p .)\end{array}$ & $\begin{array}{l}\text { Unidenti } \\
\text { fied }\end{array}$ & $\begin{array}{l}\text { Indeter } \\
\text { minate } \\
\text { conifer }\end{array}$ & $\begin{array}{l}\text { Unidenti } \\
\text { fiable }\end{array}$ & Reference \\
\hline- & $+\mathrm{ns}$ & - & - & $21 \mathrm{~F}(0.9 \mathrm{~g})$ & - & - & - & - & - & - & - & Current paper \\
\hline- & $23 \mathrm{~F}+\mathrm{ns}$ & - & - & $25 \mathrm{~F}$ & - & - & $2 \mathrm{~F}$ & - & - & - & $3 \mathrm{~F}$ & $\begin{array}{l}\text { Gregory et al. } \\
\text { 2005; } \\
\text { Simpson et al. } \\
2006\end{array}$ \\
\hline- & $+\mathrm{ns}$ & - & - & - & - & - & - & - & $\mathrm{P}$ & - & - & $\begin{array}{l}\text { Church et al. } \\
\text { 2011a; 2012a }\end{array}$ \\
\hline- & $+\mathrm{ns}$ & - & - & - & - & - & - & - & $\mathrm{P}$ & - & - & $\begin{array}{l}\text { Church et al. } \\
2011 \mathrm{~b} ; 2012 \mathrm{~b}\end{array}$ \\
\hline - & $+\mathrm{ns}$ & - & - & - & - & - & - & - & P & - & - & $\begin{array}{l}\text { Bishop et al. } \\
2013 \mathrm{a}\end{array}$ \\
\hline- & $+\mathrm{ns}$ & - & - & - & - & - & - & - & - & - & - & $\begin{array}{l}\text { Snape-Kennedy } \\
\text { et al. } 2013\end{array}$ \\
\hline- & $+\mathrm{ns}$ & - & - & - & - & - & - & - & $\mathrm{P}$ & - & - & $\begin{array}{l}\text { Church \& } \\
\text { Rowley- } \\
\text { Conwy } 2013\end{array}$ \\
\hline- & $\begin{array}{c}20 \mathrm{~F} \\
(1.1 \mathrm{~g})\end{array}$ & - & - & $60 \mathrm{~F}(4.4 \mathrm{~g})$ & - & - & - & - & - & - & - & Current paper \\
\hline $1 \mathrm{~F}(0.1 \mathrm{~g})$ & $\begin{array}{c}16 \mathrm{~F} \\
(0.4 \mathrm{~g})+\mathrm{ns}\end{array}$ & - & - & - & - & - & $70 \mathrm{~F}(10 \mathrm{~g})$ & - & - & - & $0.7 \mathrm{~g}$ & $\begin{array}{c}\text { Boardman 1995; } \\
\text { Branigan \& } \\
\text { Foster } 1995\end{array}$ \\
\hline- & $10 \mathrm{~F}$ & $23 \mathrm{~F}$ & $21 \mathrm{~F}$ & - & $7 \mathrm{~F}$ & $17 \mathrm{~F}$ & $28 \mathrm{~F}$ & $1 \mathrm{~F}$ & - & $36 \mathrm{~F}$ & $17 \mathrm{~F}$ & $\begin{array}{l}\text { Garrow \& Sturt } \\
\quad 2017 ; \\
\text { Kabukcu et al } \\
2017\end{array}$ \\
\hline- & $83 F+n s$ & - & - & $1 \mathrm{~F}$ & - & - & - & - & - & - & - & $\begin{array}{l}\text { Crone 1993a; } \\
\text { 1993b }\end{array}$ \\
\hline- & $68 \mathrm{~F}+\mathrm{ns}$ & $5 \mathrm{~F}$ & - & $29 \mathrm{~F}$ & - & - & $13 \mathrm{~F}$ & - & - & - & $7 \mathrm{~F}$ & $\begin{array}{l}\text { Inglis and Crone } \\
\text { 2016; } \\
\text { Ashmore } \\
2016\end{array}$ \\
\hline- & - & - & - & - & - & - & - & - & - & - & - & Scott 1935 \\
\hline- & - & - & - & $\mathrm{P}$ & - & - & - & - & - & - & - & $\underset{2009}{\text { McHardy et al. }}$ \\
\hline- & A & - & - & $\mathrm{P}$ & $\mathrm{P}$ & - & - & - & - & - & - & $\begin{array}{l}\text { Orr 1950; Scott } \\
1950\end{array}$ \\
\hline - & $28 \mathrm{~F}+\mathrm{ns}$ & - & - & $8 \mathrm{~F}$ & - & - & $21 \mathrm{~F}$ & - & - & $1 \mathrm{~F}$ & - & $\begin{array}{l}\text { Crone 2000; } \\
\text { Mills et al. } \\
2004\end{array}$ \\
\hline- & $0.33 \mathrm{~g}+\mathrm{ns}$ & $0.05 \mathrm{~g}$ & - & - & - & - & $0.07 \mathrm{~g}$ & - & - & - & - & $\begin{array}{l}\text { Church \& } \\
\text { Cressey 2003; } \\
\text { Dunwell et al. } \\
2003\end{array}$ \\
\hline $1 \mathrm{~F}$ & $13 \mathrm{~F}$ & $4 \mathrm{~F}$ & - & - & $19 \mathrm{~F}$ & - & - & - & - & - & - & $\begin{array}{l}\text { Downes \& } \\
\text { Badcock } \\
\text { 1999; Gale } \\
1999\end{array}$ \\
\hline - & P & - & $\mathrm{P}$ & P & - & - & $\mathrm{P}$ & - & - & - & - & Scott 1947 \\
\hline
\end{tabular}

Site numbers refer to those in Fig. 2. Taxa classed as 'cf.' were added to the definite genus identifications and numerical values represent total fragment counts or masses. The dominant charcoal taxon is highlighted in bold for each site. Uncalibrated radiocarbon dates were calibrated within Oxcal v 4.2.4 (Bronk Ramsey 2009) using Intcal13 (Reimer et al. 2013) and the earliest and latest dates were used to indicate the date range for each site. The date ranges of Mesolithic and Neolithic sites without radiocarbon dates were recorded as 8600-4000 cal вС (Bishop et al. 2014) and 4000-2500 cal BC (Bishop et al. 2009) respectively. P: wood charcoal present; A: wood charcoal abundant; F: fragment; g: grams; + ns: nutshell present; + s: seed present; S: settlement/domestic evidence (stone walls, pits, post-holes, hearths, occupation horizons, ash spreads); CC: chambered cairn; SC: stone circle; $*=$ much of the charcoal from Calanais is residual and may relate to earlier Neolithic activities at the site rather than from wood used during the construction and use of the monument (c. 3000-1700 cal BC) and hence the charcoal assemblage was considered by the excavator to have formed over a much longer period (c. 5350-1690 cal BC: Ashmore 2016) 


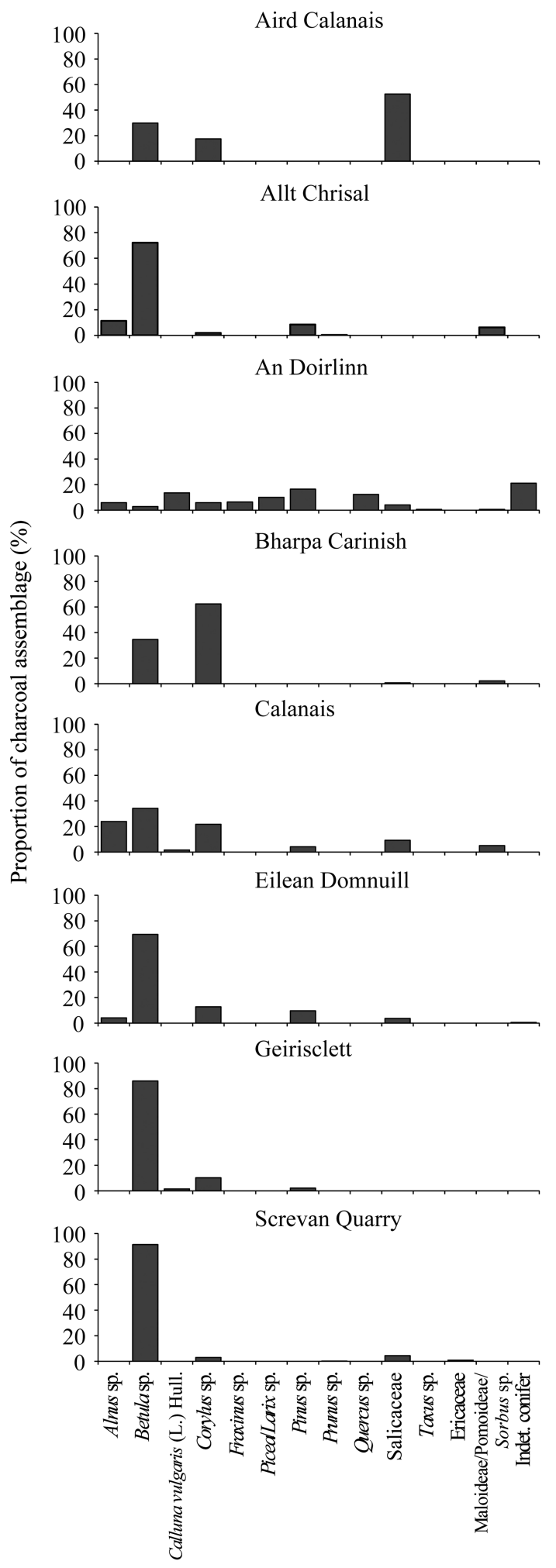

Fig. 7.

Summary of the main species present in Neolithic charcoal assemblages in the Western Isles. The proportion of each taxa was calculated for each assemblage with fragment counts \& masses (see Table 6), as the overall percentages based on both methods are approximately equal (Chabal 1990; Miller 1985, 4) 
(a)

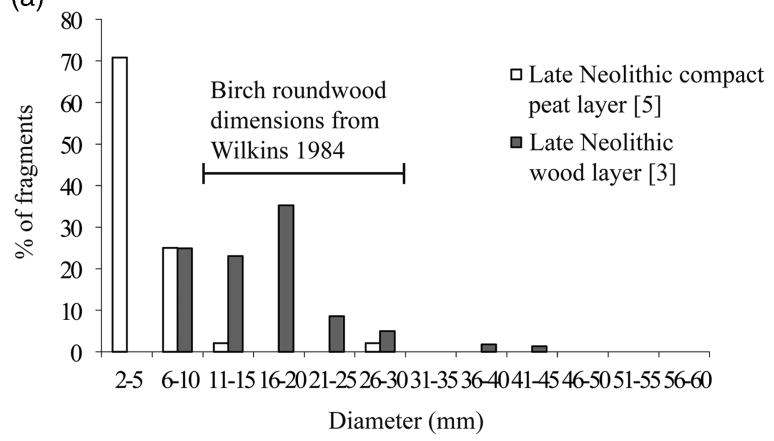

(b)

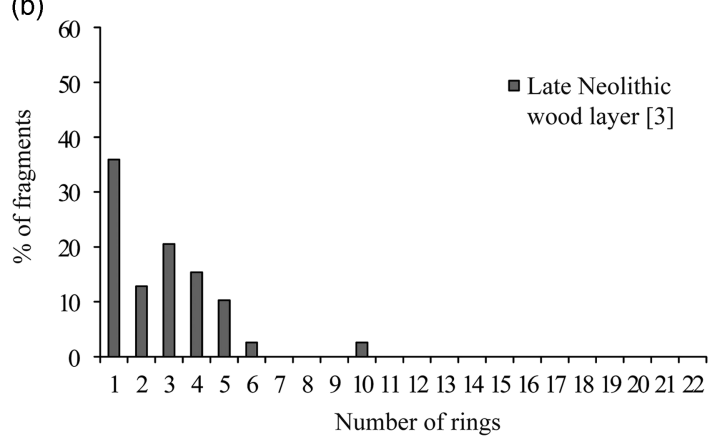

(c)

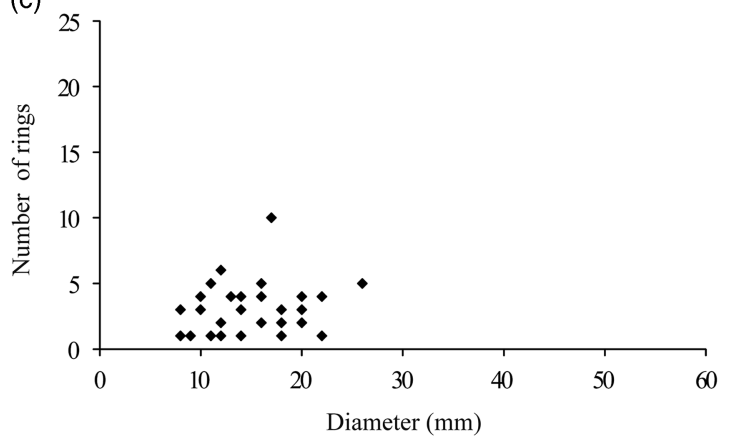

Fig. 8.

Age and diameter of wood remains from Aird Calanais: (a) birch roundwood (pith to bark) diameters from contexts $3 \& 5$. A bar has been placed on the chart to indicate the main range of the birch diameters in the wood layers recorded by Wilkins (1984); (b) birch roundwood (pith to bark) ring counts from the late Neolithic wood layer (context 3); (c) scatter plot of birch roundwood (pith to bark) ring counts $\&$ diameters from the late Neolithic wood layer (context 3 ). The categories $\&$ scales for the graphs are the same as used in Out et al. (2013), to allow ease of comparison with their age/diameter models for woodland management. Some of the rings of the measured wood fragments could not be counted due to poor preservation, \& consequently these fragments are shown on graph (a), but not on graph $(\mathrm{c})$
RESEARCH QUESTION 2: WHAT WERE THE TIMING, NATURE, \& MECHANISMS OF DEFORESTATION IN THE CALANAIS LANDSCAPE?

The earliest evidence for woodland decline in the Calanais landscape (6309-5680 cal вC) was identified in a previously published pollen record, Calanais-3, a peat column taken approximately $0.5 \mathrm{~km}$ from the main Calanais monument (Figs $1 \& 10$; Bohncke 1988; Bohncke et al. 2016). The decline is correlated with an increase in microcharcoal. As with the charred plant macrofossils recovered from the palaeosol at Aird Calanais, this could represent Mesolithic huntergatherer activity (Bohncke 1988; Edwards 1996), or could relate to natural fires (Tipping 1996). However, as Bohncke et al. (2016, 833) note: 'There need have been no causal relation between the loss of Betula and burning because charcoal fragments may have become more common in the peat as the Betula canopy was reduced'. For instance, it is possible that the microcharcoal was derived from Mesolithic hearths (Edwards 1996, 31). Whether or not the Mesolithic woodland decline had an anthropogenic origin, vegetation management to attract deer for hunting was probably not responsible (contra Bohncke 1988) because there is currently no evidence for Mesolithic deer in the Western Isles (see below; Bishop et al. 2015, 67-8).

After the Mesolithic woodland decline, the woodland regenerated (Fig. 10; Bohncke et al. 2016) before further woodland decline became evident. The decline in birch pollen in the late Neolithic wood layer at Aird Calanais (*2916-2878 cal BC) correlates with the first of two major late Neolithic/Bronze Age birch declines at Calanais-3 (*2897-2555 cal вс; Figs $1 \& 10)$. The data suggest that there was a staged clearance of woodland across the Calanais landscape: the calibrated date range for the start of the late Neolithic woodland decline at Calanais-3 extends much later than the dated decline at Aird Calanais (Fig. 10) and the late Neolithic decline in AP (from $75 \%$ to $28 \%$ ) at Calanais-3 was gradual, extending over a period of several hundred years (c. 2900-2500 cal BC; Bohncke et al. 2016). In contrast, AP values declined from $78 \%$ to $16 \%$ after the rapid birch decline at Aird Calanais (c. 2900-2800 cal BC) before declining to $5 \%$ at c. 2860-2730 cal BC, suggesting that the wood layer marked the final woodland decline at this site. At Calanais-3 there was also a Bronze Age decline, and an early Neolithic wood layer (4229-3800 cal BC), which may represent another decline phase (Fig. 10). 


\section{R.R. Bishop et al. DEFORESTATION \& HUMAN AGENCY, WESTERN ISLES OF SCOTLAND}
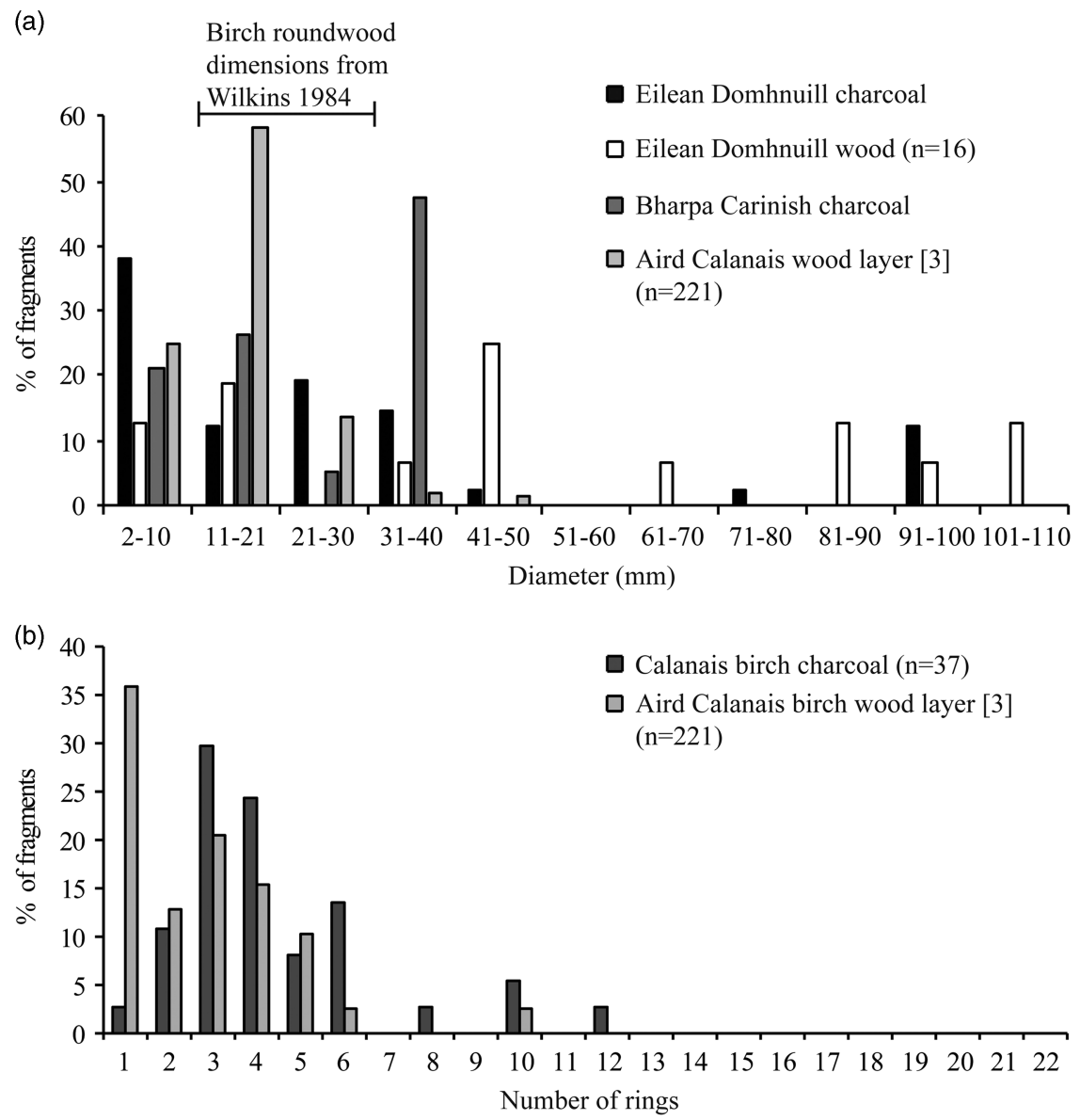

Fig. 9.

(a) birch roundwood (pith to bark) diameters for wood \& charcoal assemblages in the Western Isles with $>10$ measured fragments. A bar has been placed on the chart to indicate the main range of the birch diameters in the wood layers recorded by Wilkins (1984); (b) birch roundwood ring counts for wood and charcoal assemblages in the Western Isles with $>10$ recorded fragments

Though natural factors appear to have contributed to woodland decline around Aird Calanais, it is evident that Neolithic people were active in the area prior to the woodland decline. As well as the early Neolithic hearth at Aird Calanais, there is pollen evidence for early Neolithic cereal cultivation in the Calanais landscape (earliest cereal pollen evidence radiocarbon dated to 3875-3605 cal BC: see Fig. 10; Ashmore 2016, 985). The charcoal recovered from Ashmore's (2016) Calanais I excavations provides evidence for a long period of fuel use (c. 5350-1690 cal BC), showing that people were exploiting the main local trees (mostly birch, hazel, and alder: Alnus sp.) for fuel (Fig. $7 \&$ Table 5). The age profiles of the charcoal fragments suggest that people were primarily using young branches $(<10$ years old $)$ for firewood rather than whole trees (Fig. 9b; Inglis \& Crone 2016). Such a strategy would have had little impact on the local woodlands because birch, hazel, and alder all coppice well (Rackham 2006, 12) and so the harvesting of young branches would have resulted in regeneration. This is supported by the pollen evidence, which shows that hazel and alder remained relatively stable during the birch decline (Bohncke et al. 2016).

It is likely that other human activities had a greater impact on the woodlands than firewood procurement. There is considerable archaeological evidence for human activity in the Calanais landscape in the first half of the 3rd millennium cal BC, when AP values at Calanais-3 declined from c. $75 \%$ to $c .28 \%$, and at 
OxCal v4.2.4 Bronk Ramsey (2013); r:5

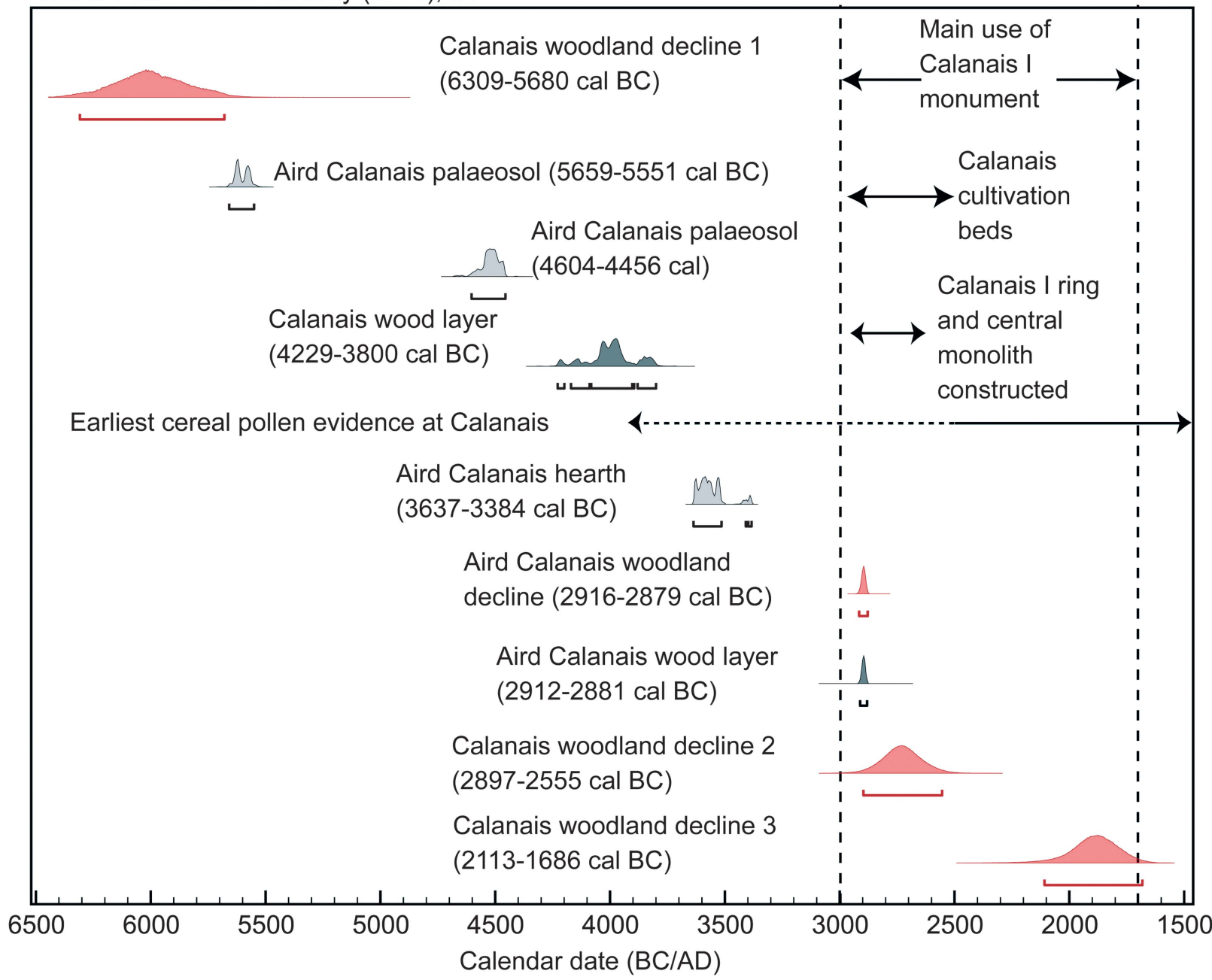

Fig. 10.

Summary of the dates for the palynological, archaeological, \& archaeobotanical evidence in the Calanais landscape. The woodland decline date ranges correspond to those shown in Fig. 11. The radiocarbon dates from the Aird Calanais wood layer \& hearth (see also Table 1) \& the Calanais wood layer were combined \& calibrated using OxCal v 4.2.4 (Bronk Ramsey 2009) using IntCal13 (Reimer et al. 2013). The dashed line for the cereal pollen at Calanais-3 shows the period when cereal pollen was first present in the sample, but indicates that it was discontinuously present during this period. The solid cereal line for the cereal pollen indicates the period when cereal pollen was continuously present at Calanais-3

Aird Calanais from 78\% to 5\%. Deforestation at Aird Calanais and Calanais-3 occurred about the same time as the construction of the ring and central monolith at Calanais I (c. 2950-2650 cal BC), as well as the use of cultivation beds (2980-2510 cal BC; Fig. 10), which underlie and therefore pre-date the monument (Ashmore 2016). Cereal pollen was identified in the Calanais-3 pollen record during the early part of this phase, and later grazing indicators such as Ribwort Plaintain (Plantago lanceolata L.) and grasses (Poaceae) increased (Bohncke 1988; Bohncke et al. 2016). At Aird Calanais, there is some potential evidence for grazing during the Neolithic, but not for cereal cultivation: Poaceae and Plantago lanceolata/Plantago undiff. pollen increased and spores which may be associated with animal dung (Type HdV-55A, Sordaria-type: van Geel et al. 2003) were also sporadically present, but cereal pollen was absent. All of these activities would have reduced woodland coverage: 


\section{R.R. Bishop et al. DEFORESTATION \& HUMAN AGENCY, WESTERN ISLES OF SCOTLAND}

woodland may have been deliberately cleared around the monument or to create new agricultural land, and grazing would have prevented woodland regeneration. The imprecision of the dating evidence (Fig. 10) means that it is not possible to establish which of these activities played a greater role in the woodland clearance. Nevertheless, both Neolithic activities and climatic deterioration contributed to woodland decline.

Despite this substantial woodland decline, minimum AP values remained above $20 \%$ throughout the Neolithic at Calanais-3 (Bohncke 1988; Bohncke et al. 2016; see below). For much of the period c. 3000$2000 \mathrm{cal}$ BC, AP values at Calanais-3 were over $40 \%$ and reached a maximum of $75 \%$ in the earlier part of this period. This suggests that the landscape around the Calanais I monument was at least partially wooded during the main period of its use (cf. Fossitt 1994, 373). Sites with wider pollen source areas also show that woodland remained important in North Lewis at this time: at Loch na Beinne Bige, AP values ranged between $75 \%$ and $93 \%$ and at Loch na Muilne, AP values were between $44 \%$ and $78 \%$ during the Neolithic (Lomax 1997).

The wooded nature of the Neolithic landscape around Calanais I has significant implications for understanding the way the monument was experienced. It has been suggested that, in contrast to henges which formed a visual barrier between the observer and the surrounding landscape, open stone circles such as Calanais I were deliberately constructed in positions which would allow the observer to see significant landscape features, such as mountains and other monuments (Bradley 1998, 116; 2002, 130), perhaps in relation to movements of the moon (Curtis \& Curtis 1994; Ashmore 2016, 1067). Considering the evidence for staged woodland clearance in the Calanais landscape, together with the dynamic nature of woodlands, it is probable that visibility from the monument changed considerably, both seasonally and over decades to centuries (Gillings \& Wheatley 2001, 33; Cummings \& Whittle 2004, 69-71).

The nature of the woodland would have affected visibility from the monument. Woodlands on the Western Isles may have consisted of relatively open scrub (Tipping 1994), and trees of birch, willow, and hazel may have been wind-pruned and shrub-like (< 5m high: Stace 2010), particularly in more exposed locations (Green 1964, 30; Mackenzie 2000, 4). Nonetheless, even the presence of scrub-woodland of up to $5 \mathrm{~m}$ high would have significantly influenced visibility from Calanais I. It is also evident that more substantial trees grew in some locations in Lewis at this time: Wilkins (1984) recorded a prehistoric pine trunk that was $6 \mathrm{~m}$ long. Moreover, the high tree pollen values in the Calanais-3 core and elsewhere in North Lewis suggest that wind damage was not a major influence on the presence of woodland in this area. Thus, woodland would most likely have concealed important topographical features from view during much of the Neolithic.

This suggests that the wooded surroundings were central to the way Calanais I was experienced. Anthropological studies indicate that trees often provide important metaphors for human lifecycles, fertility, and regeneration, and in many societies trees have been seen as the dwelling places of ancestors and spirits (Austin 2000, 75; Noble 2006, 97-9). Monuments such as Calanais I may have been deliberately placed within wooded environments because of these types of symbolic associations and beliefs (cf. Austin 2000, 75; cf. Cummings \& Whittle 2004, 71). The extent of landscape openness around other stone circles in Scotland in the late Neolithic/Bronze Age is difficult to identify due to the rarity of pollen sampling in the vicinity of stone circles, but appears to have varied, with some stone circles probably constructed in predominantly open landscapes (eg, the Ring of Brodgar and the Stones of Stenness, West Mainland, Orkney: cf. Jones 1979 and Farrell et al. 2014; Renfrew 1979; Ritchie 1976), enabling landscape features to be seen, and others situated in open to semi-open woodland (eg, Machrie Moor, Arran: Robinson \& Dickson 1988; Haggarty 1991), which would probably have concealed the view of significant topographical features. The variability of the environment around these stone circles, and through time, suggests that not all of these monuments were primarily intended as places from which to view these features.

\section{RESEARCH QUESTION 3: WHAT DOES THE REGIONAL POLLEN \& PLANT MACROFOSSIL EVIDENCE REVEAL ABOUT THE TIMING, EXTENT, \& MECHANISMS FOR WOODLAND DECLINE IN THE WESTERN ISLES?}

\section{Timing o extent of woodland decline in the Western} Isles: the pollen evidence

The systematic approach to data synthesis adopted here highlights some of the challenges inherent with the synthesis of palynological data at a regional level. The dates of the main phases of woodland decline in the Western Isles remain imprecise (Fig. 11). The 


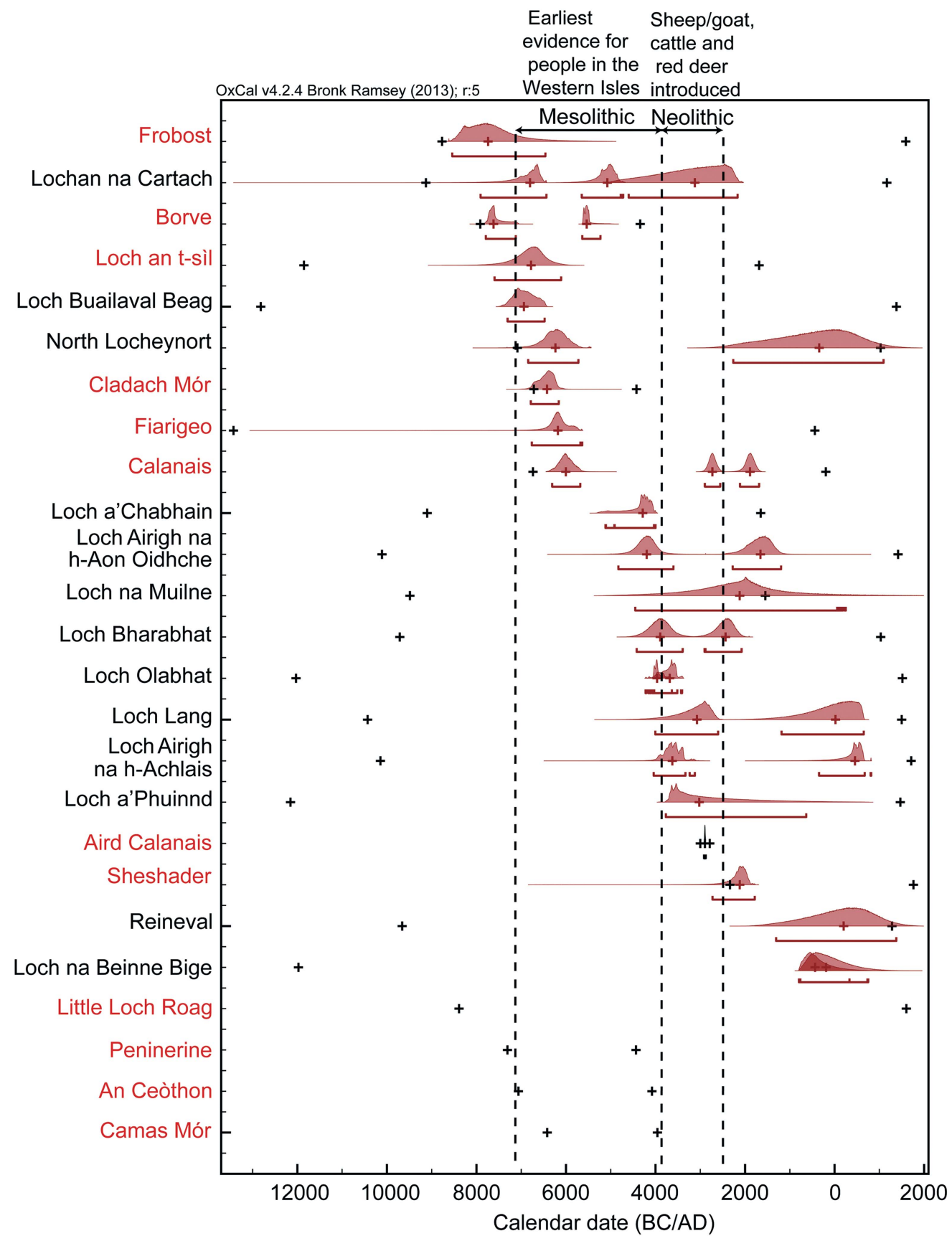

Fig. 11.

Dates of major woodland declines in the Western Isles of Scotland, ordered sequentially (the declines were initially ordered from north to south by island but no pattern was observed). The site names highlighted in red are from peat/organic deposits/ mires $\&$ the site names in black are loch sites. + : the median of the modelled dates for the start $\&$ end of each sequence. Dashed lines indicate the approximate start \& end of the Mesolithic \& Neolithic periods in the Western Isles. The start of the Neolithic marks the first introduction of large herbivores, including red deer, sheep/goat, \& cattle into the Western Isles. Where no decline is shown, there was no major decline in woodland as defined in the methodology. 


\section{R.R. Bishop et al. DEFORESTATION \& HUMAN AGENCY, WESTERN ISLES OF SCOTLAND}

major problem is the poor chronological control on the data, resulting from too few dates, particularly close to the major woodland declines (Parnell et al. 2011), and often the imprecision inherent in conventional, rather than AMS, radiocarbon dating. Consequently, many of our modelled dates of woodland decline are associated with large uncertainties.

Establishing the spatial coverage and extent of woodland in past environments is also notoriously difficult (eg, Sugita et al. 1999; Bunting et al. 2004; Fyfe et al. 2010; 2013), particularly in environments that are marginal for woodland (Wilkins 1984; Fossitt 1994; 1996, 192; Gearey \& Gilbertson 1997; Edwards et al. 2000; Bunting 2002; Bunting \& Farrell 2017). Analyses of modern pollen rain have shown that in the relatively open windswept areas of northwest Scotland, a pollen sampling site must be within 50 $\mathrm{m}$ of a woodland for percentages of local AP to be higher than background AP levels, and that values as low as $15-20 \%$ AP in peat sites could reflect abundant local woodland under these conditions (Bunting 2002). Other analyses of British pollen sites have also demonstrated that high levels of local on-site nonarboreal taxa can mask the true abundance of arboreal pollen in an area (Fyfe et al. 2010). Conversely, a model-based analysis of 73 British pollen sequences suggested that AP percentages systematically underestimate the extent of landscape openness (Fyfe et al. 2013), a pattern previously noted for other parts of Europe (eg, Sugita et al. 1999). Consequently, AP values can only be used as a guide for understanding the extent of prehistoric woodland coverage.

Despite these caveats, our analysis suggests that the majority of the woodland declines were not restricted to the Neolithic in the Western Isles, thus corroborating previous research that has highlighted the temporal variability of woodland decline in the region (Brayshay \& Edwards 1996; Fossitt 1996; Bennett et al. 1997; Edwards et al. 2000; Fyfe et al. 2013). The first phase of woodland clearance occurred before the Neolithic for at least $50 \%$ of the sites, showing that though there is evidence for a major phase of clearance in the Neolithic at several sites, such as at Aird Calanais, Calanais-3, and Loch Olabhat (Fig. 11), much woodland had already been lost before this time. A notable proportion $(20 \%)$ of the declines in woodland first occurred after the Neolithic period, but most post-Neolithic clearances represent secondary declines of already diminished woodlands.
There is no obvious geographical trend in the timing of woodland decline across the Western Isles (Figs 11 \& 13). However, all of the major declines at the non-loch sites occurred before c. 1500 cal BC (Fig. 11). This could reflect the location of these sites (areas susceptible to the spread of peat) and their local pollen source area: several of the early declines (Calanais, Aird Calanais, Sheshader, Frobost, Borve, Cladach Mor) are located towards the bottom of the sample columns, and so the woodland declines may reflect the date of the onset of peat formation around these sites and the consequent reduction in woodland in these areas.

Likewise, there was no clear north-south or east-west trend in terms of minimum and maximum AP values across the Western Isles, nor was there an apparent association between site type (loch vs. non-loch sites) and the minimum and maximum AP values (Fig. 13). However, the pollen records suggest that the nature of woodland decline could vary, from single relatively short declines (e.g. Sheshader, Loch Buailaval Beag, Aird Calanais, Loch Olabhat) or multiple short and/or gradual declines at some sites (e.g. Loch na Beinne Bige, Loch Airigh na h-Aon Oidhche and Calanais) to a slow, progressive decline at others (e.g. Loch a'Phuinnd: see Table 4 for site references), and this variation is not apparent when datasets are aggregated to produce regional syntheses (cf. Fyfe et al. 2013).

Thus, despite the problems in estimating absolute landscape openness from AP percentages, our analysis (Figs 11-14) shows that: 1) although some woodland remained at most sites in the Neolithic, maximum Neolithic AP percentages were typically much lower than before, suggesting a more restricted woodland coverage than in the Mesolithic; 2) AP continued to decline further after the Neolithic at most sites; and 3) several sites, such as Little Loch Roag, Camas Mór, and Fiarigeo had very low AP during the Neolithic.

\section{Timing \& extent of woodland decline in the Western Isles: the archaeobotanical evidence}

The Neolithic macrofossil evidence, including the new data from Aird Calanais, demonstrate that Neolithic woodland cover remained more extensive than at present. The predominant fuels exploited (Fig. 7; Table 5) were birch, hazel, and willow/poplar, and coniferous species were scarce (mostly pine, likely representing Scots Pine: Pinus sylvestris L., which is the only native pine in the Western Isles: Mullin \& Pankhurst 1991). All 

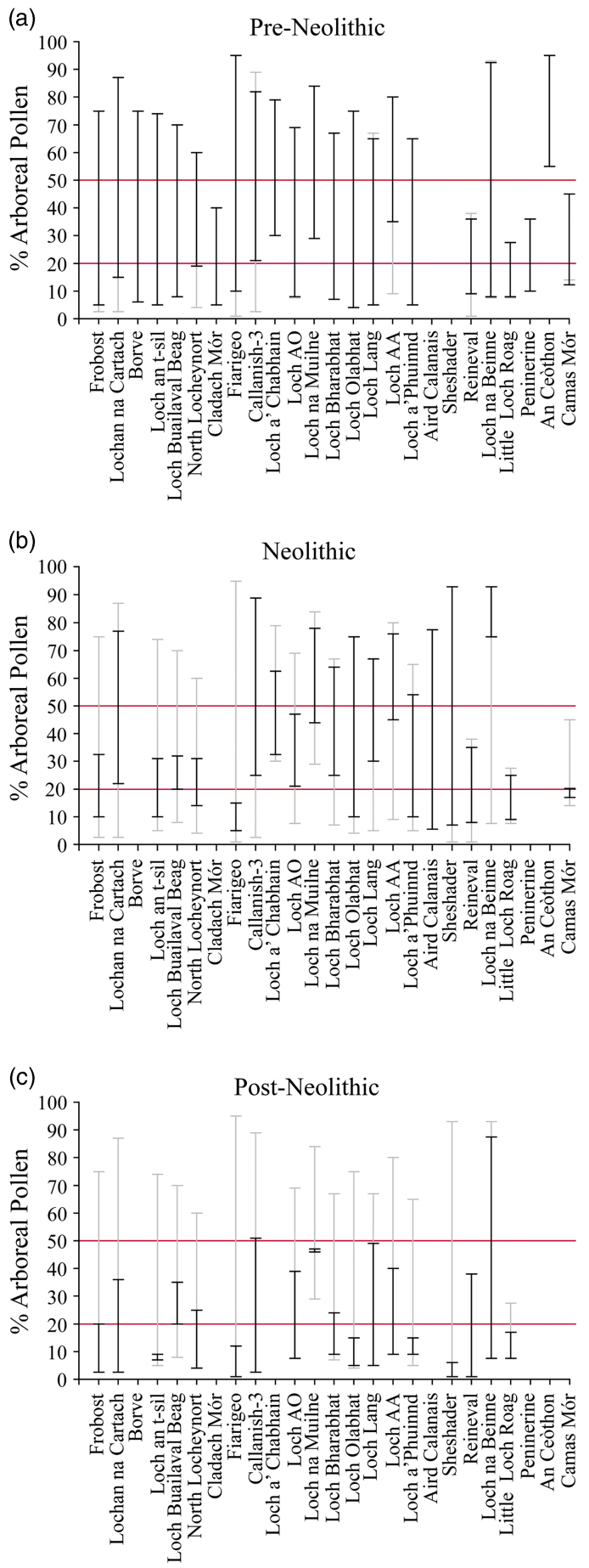

Fig. 12.

Minimum \& maximum arboreal pollen percentages from pollen sites in the (a) pre-Neolithic, (b) Neolithic, and (c) postNeolithic (see Table 4 for site details). The OxCal age-depth models were used to estimate the start (4000 cal $\mathrm{BC}$ ) and end $(2500 \mathrm{cal} \mathrm{BC})$ of the Neolithic in each sequence. Black lines denote minimum \& maximum pollen percentages for each period, grey lines denote minimum and maximum pollen percentages for each sequence $\&$ red lines denote major thresholds of AP $(20 \% \& 50 \%)$. The sites are ordered sequentially as in Fig. 11, with the earliest dated woodland declines to the left of the chart. LAA: Loch Airigh na h-Achlais. LAO: Loch Airigh na h-Aon Oidhche 


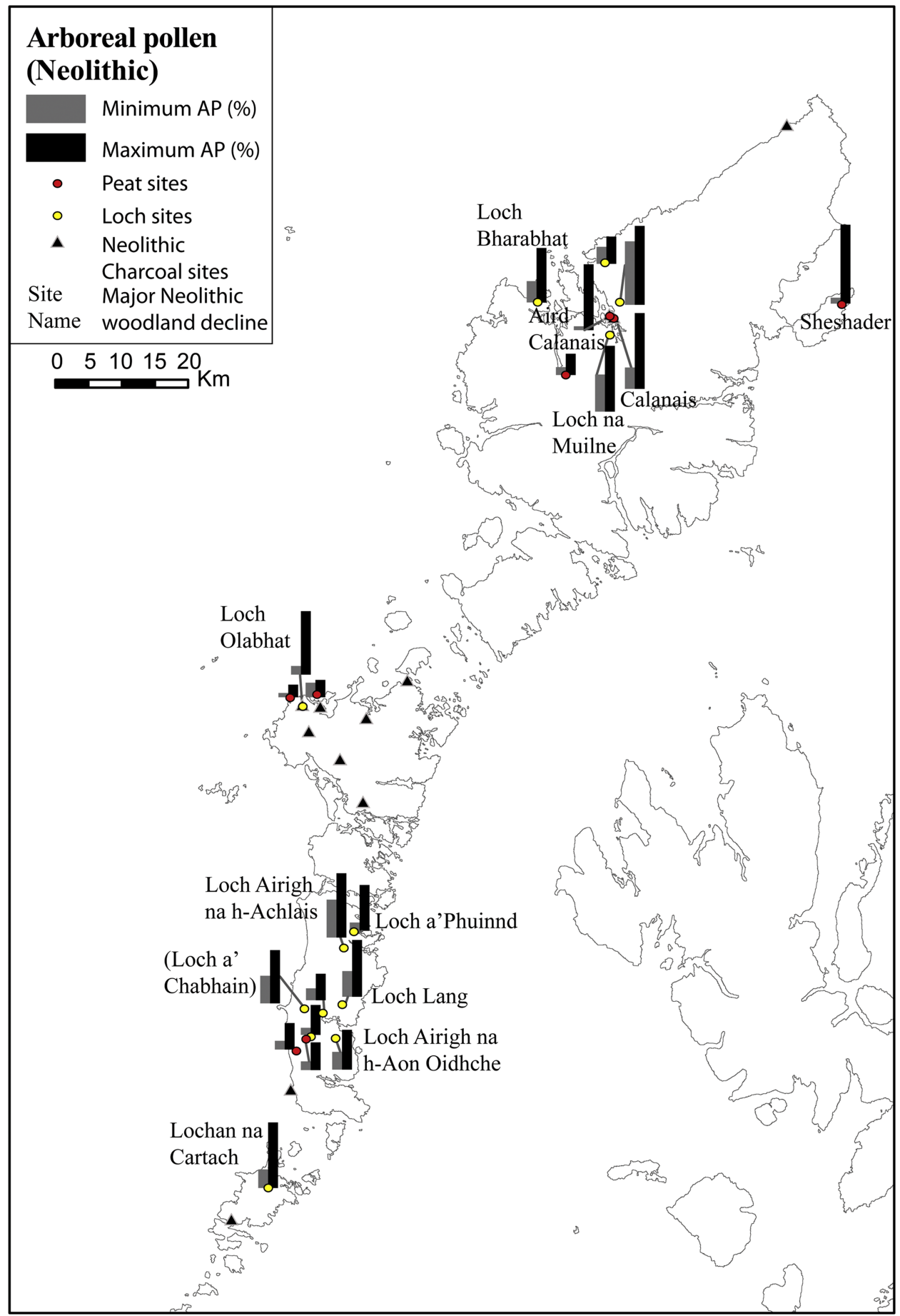

Fig. 13.

Proportion of arboreal pollen for the Neolithic phases of the pollen sites across the Western Isles (see Table 4), shown in relation to the location of the Neolithic sites with charcoal (Table 6). The site names are given for the sites which have a major Neolithic woodland decline, as shown in Fig. 11. The site of Loch a' Chabhain is also highlighted here, because though the woodland decline starts at the very end of the Mesolithic phase (Fig. 11), the woodland decline phase extends into the start of the Neolithic (Mulder 1999) 

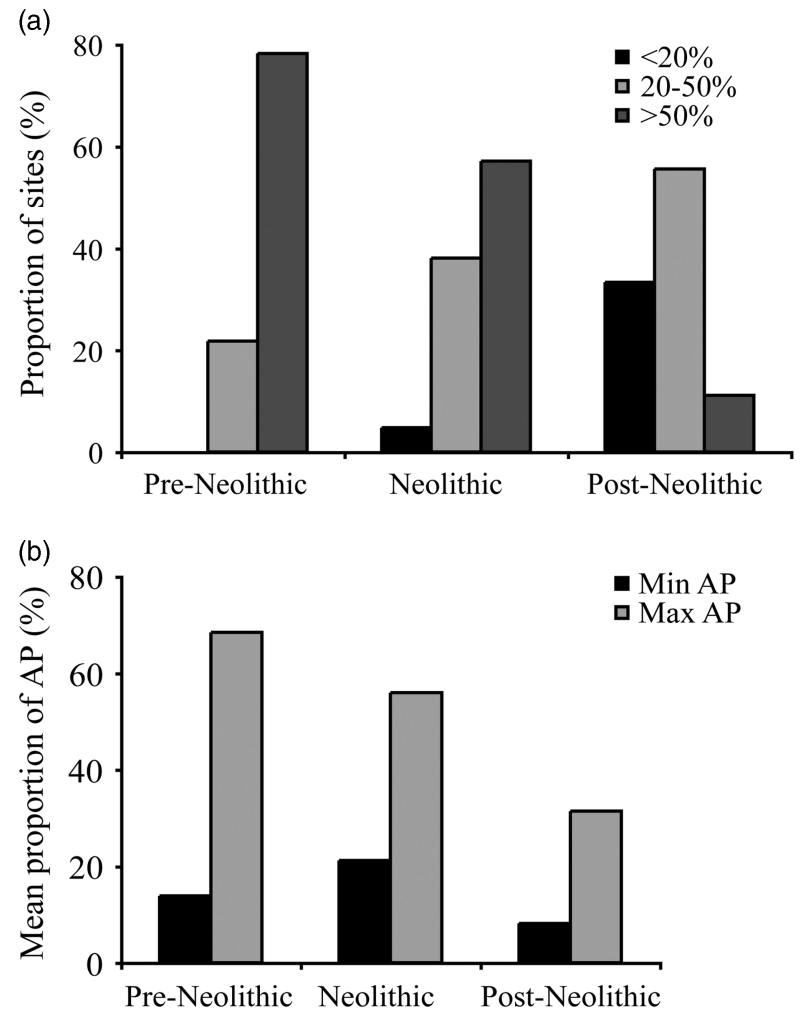

Fig. 14.

Summary of the proportion (\%) of arboreal pollen from sites across the Western Isles (see Table 4); (a) maximum arboreal pollen values; (b) minimum $\&$ maximum arboreal pollen values

of these woods could have been collected from the woodlands close to the Neolithic sites: birch and/or hazel were the dominant trees/shrubs in the pollen diagrams across the Western Isles, with alder, oak and pine also important in some locations (see Table 4 for references). Willow/poplar were relatively scarce in the pollen diagrams, but considering the relatively poor pollen productivity of willow (Bradshaw 1981), it may have been a locally important component of the vegetation. This contrasts with later prehistoric and historic periods of the region, when plant macrofossil suggests that people were reliant on turf, peat and driftwood for primary fuels (Church et al. 2007b) due to the more restricted woodland availability (Figs $12 \& 14$ ). Thus, despite the woodland declines, Neolithic woodlands were still sufficiently abundant to provide an adequate fuel source.

However, there is some evidence that Neolithic people implemented strategies to deal with the more restricted woodland availability. Soil micromorphological evidence from Neolithic soils, together with the ecology and abundance of 'weed' seeds in Neolithic archaeobotanical assemblages from the Western Isles, suggests that other materials were sometimes used for fuels at this time - principally turf, and to a lesser extent dung and peat (Mills et al. 2004; Bishop et al. 2009). Likewise, the charcoal assemblage from the Neolithic site at An Doirlinn, South Uist, suggests that woodlands were less readily available in this area. The assemblage contained a notable proportion of heather - a small shrub which is less preferable for burning than other larger taxa - and the only evidence for non-native driftwood (spruce/larch: Picea/Larix sp. and possibly yew: Taxus sp.) exploitation for fuel in the Neolithic of the region (Fig. 7; Table 5). The inhabitants of the site also collected deadwood from large branches or trunks of pine (Kabukcu et al. 2017).

While driftwood and heather were used at other Neolithic sites in the Western Isles, it seems that it was mostly selected for purposes other than burning. At Eilean Domnuill, North Uist, a single waterlogged post of the non-native species larch (probably driftwood - cf. Dickson 1992) was discovered together with birch and willow stake/post remains and heather twigs (Crone 2000). The absence of non-native woods and heather in the charcoal assemblage suggests that though whole driftwood trees were sometimes collected for construction, and heather for thatching, bedding or rope-making, native trees were usually sufficiently abundant for firewood collection in the Neolithic (ibid.).

\section{Mechanisms of woodland decline in the Western Isles}

It is difficult to disentangle the different processes contributing to woodland loss in the region (Bennett et al. 1997; Edwards et al. 2000; Church 2006). The consequences of multiple short-term and long-term processes - pedogenesis and paludification, climate change, machair development and sea-level rise, and human impacts of different kinds from the Mesolithic onwards - are likely all reflected in the pollen records. The relative importance of these processes at particular sites in the Western Isles have been discussed at length elsewhere (see Table 4 references). However, there are three novel points to be made with reference to potential human impacts in the Neolithic that emerge from our synthesis of pollen and plant macrofossil data, and from the archaeological record. 


\section{R.R. Bishop et al. DEFORESTATION \& HUMAN AGENCY, WESTERN ISLES OF SCOTLAND}

First, a range of different Neolithic practices would have caused temporary or small-scale reductions in woodland (cf. Bishop et al. 2015 on Mesolithic impacts), but not all of these strategies would have resulted in large-scale woodland decline. For example, significant woodland clearances would not have been required for cereal cultivation (Jones 2005) because Neolithic cereals were probably grown in small-scale permanent plots close to settlements (Barclay 2003, 148; Bogaard \& Jones 2007). Clearing forests of mature trees for settlements and arable plots with stone axes or by ring barking would have been challenging, and existing open areas were probably primarily used and expanded where necessary (Brown 1997; Bell \& Noble 2012, 81). Similarly, Neolithic firewood collection would have had a minimal impact on woodlands. Though birch and hazel were the main species used for fuel (Table 5; Fig. 7), current evidence suggests that Neolithic people were mainly using narrow diameter branches and twigs $(<40 \mathrm{~mm})$, rather than trunks or rootwood for firewood (Fig. 9; Boardman 1995, 153; Gale 1999; Crone 2000, 45; Kabukcu et al. 2017). Age and size data from individual charcoal assemblages are not available and so it is not possible to assess whether the firewood was systematically harvested from sustainably-managed woodlands (eg, by coppicing: Out et al. 2013). However, as mentioned previously, birch, hazel, willow/poplar and alder all coppice well (Rackham 2006, 12) and so would regenerate if living branches were harvested.

On the other hand, the removal of whole trees for construction may have been a major cause of woodland decline. Whole trees would have been harvested for structural timbers in houses (post-holes are present at several sites), for fencing, and as substructure for semi-artificial islet settlements, for example Eilean Domnhuill (see fig. 9; Crone 2000; Mills et al. 2004).

Likewise, the Neolithic introduction of large terrestrial mammals to the Western Isles would have had a major impact on the woodlands (Bennett et al. 1997, 137; Mills et al. 2004, 892; cf. Dugmore et al. 2005; Bohncke et al. 2016). The area possessed no native mammalian fauna, except for pygmy shrews, voles/mice, and hares (Serjeantson 1990; HamiltonDyer 2005; Fairnell \& Barrett 2007), because the $27 \mathrm{~km}$ wide channel between the mainland and the Western Isles prevented most terrestrial mammals from colonising naturally. Mesolithic excavations in the region (see Table 5; see also Bishop et al. 2010; 2011) have so far produced no evidence for native large herbivores (Hamilton-Dyer 2005; Peter Rowley-Conwy pers. comm.), suggesting that Mesolithic people did not introduce them to the islands. Red and roe deer were present in the Inner Hebrides from the Mesolithic onwards (Kitchener et al. 2004), but the earliest examples from the Western Isles, (eg, Eilean Domhnuill: 3792-2356 cal BC; Mills et al. 2004) date to the Neolithic (Serjeantson 1990; Smith \& Mulville 2004; Finlay 2006; Schulting 2013), when they were probably introduced (Serjeantson 1990; Stanton et al. 2016) together with sheep/goat, cattle, and pigs. With the absence of grazing mammals prior to the introduction of farming, the woodlands of the Western Isles would have been more susceptible to the impacts of Neolithic grazing. Therefore, Neolithic grazing by domesticates and deer would have maintained and expanded woodland clearings on an unprecedented scale (see Fig. 11).

Secondly, while it is tempting to link the Neolithic woodland declines to an increase in human population size after the Mesolithic and a resulting increase in the intensity of land use (Woodbridge et al. 2014), it is not strictly possible to assess whether Mesolithic populations were smaller than Neolithic/Bronze Age populations, because Mesolithic sites are severely under-represented in the archaeological record. The first Mesolithic site was only identified in 2001 at Northton, Harris (Gregory et al. 2005), and apart from the new archaeobotanical evidence of possible anthropogenic origin at Aird Calanais, there are just five other known Mesolithic sites in the region (Table 5). Rather than indicating a rarity of Mesolithic communities in the area, the scarcity of sites probably reflects the generally ephemeral nature of Mesolithic sites in Scotland (Wickham-Jones 2004), the difficulty of locating such evidence under thick peat and machair deposits, and the drowning of coastal sites by Holocene relative sea level rise (Edwards 1996, 34; Edwards \& Sugden 2003, 11). It is possible that the rich marine resources available on the islands could have sustained relatively large Mesolithic populations, as has been suggested for Mesolithic hunter-gatherer communities in southern Scandinavia through analogy with recent sedentary hunter-gatherer groups in North America (Rowley-Conwy 1983; 2011, 440). Consequently, it is possible that Mesolithic and Neolithic population sizes in the Western Isles were not dissimilar.

Thirdly, since a large proportion of the woodland declines occurred prior to the Neolithic, the introduction of Neolithic practices cannot have been the 
only cause of primary woodland decline in this region. Natural climatic and environmental changes, alongside Mesolithic exploitation of woodlands (Edwards 1996; Bishop et al. 2015) were also important. At least one of the declines (eg, Borve: 7790-7122 cal BC) occurred before the earliest evidence for Mesolithic occupation of the Western Isles (Fig. 11; earliest evidence from Northton, Harris at 7051-6104 cal BC: Gregory et al. 2005; Simpson et al. 2006; Ascough et al. 2017), which suggests a natural cause for at least some of the declines. As noted above, many of these early woodland declines may relate to the localised spread of peat around the sampling sites. Indeed, it is notable that a high proportion of the woodland declines (Fig. 11) fall within the two main phases of dated wood preservation within peat (c. 8600-6000 cal BC and c. 4000-2000 cal BC: Figs $11 \& 15$, Table 6), the latter of which appears to reflect a regional pattern of fossil wood preservation occurring elsewhere in North-west Europe (McGeever \& Mitchell 2015). Bennett et al. $(1997,129)$ similarly observe that 'trees tend to be preserved when, on a regional scale, woodland is in decline' and Wilkins (1984, 256) proposes that macroscopic wood remains are likely to represent 'the end of a period of tree cover'. Consequently, the wood layers in peat may provide a proxy for the beginning of particular periods of accelerating blanket peat expansion, reflecting increased bogsurface wetness, perhaps linked to an increasingly wet climate (Fossitt 1996, 193). The absence of fossil wood within the peat in subsequent periods could reflect the fact that the bog and surrounding area had become too wet for further tree growth (Edvardsson et al. 2012), as well as a decline in the availability of local seed sources for recolonisation after the woodland declined (McGeever \& Mitchell 2015). Hence blanket peat expansion was most probably responsible for many of the Mesolithic and Neolithic woodland declines.

Overall, the available evidence suggests that the frequency and extent of woodlands in the Western Isles began to be reduced in many areas during the Mesolithic and that the woodlands were reduced still further during the Neolithic period. This was most likely primarily a consequence of the direct harvesting of trees for construction purposes and the spread of blanket peat in the Mesolithic and Neolithic, as well as the introduction of grazing mammals in the Neolithic. However, despite the woodland declines, tree populations remained sufficiently abundant for Neolithic fuel procurement. This suggests that though the initiation of Neolithic practices accelerated woodland decline, it was not the introduction of farming per se that destroyed the woodlands.

RESEARCH QUESTION 4: WHAT IMPLICATIONS DOES THE EVIDENCE FROM THE WESTERN ISLES HAVE FOR UNDERSTANDING THE INTERACTIONS BETWEEN FIRST FARMERS \& WOODLANDS IN THE NORTH ATLANTIC REGION?

It is often assumed that woodland decline was an automatic consequence of the introduction of farming: hunter-gatherers are often perceived as ecologically skilled managers, whereas farmers are often viewed as inherently ecologically damaging (Austin 2000, 72-3; Warren 2005, 69). As discussed, deforestation in the Western Isles began prior to the introduction of farming. Therefore, a key question is whether the first farmers were generally responsible for destroying the woodlands as they colonised the North Atlantic region.

The spread of agriculture across the North Atlantic region was initiated within contrasting cultural and social systems - by Neolithic farmers (c. 3800 cal BC) in Atlantic Scotland (Western Isles, Orkney, Shetland) and by Norse settlers in the Faroes, Iceland, and Greenland (9th-11th centuries cal AD). Despite the cultural differences between Neolithic farmers and the Norse, comparable small-scale farming systems, based principally on the husbandry of cattle and sheep/goat (Church et al. 2005; Dugmore et al. 2005; Schulting 2013) and the cultivation of barley (Scotland: Bishop et al. 2009; Faroe Islands: Church et al. 2005; Iceland: Guðmundsson 2009; Zori et al. 2013; Bishop \& Guðmundsson in prep.) were introduced throughout the area. Climatic and ecological differences across the region allow useful parallels to be drawn between the different environmental settings.

\section{Orkney and Shetland}

In contrast to the other areas of the North Atlantic settled by the first farmers, both the Western Isles and Orkney had a pre-existing Mesolithic population for several millennia prior to the introduction of farming (Gregory et al. 2005; Lee \& Woodward 2009; Farrell et al. 2014, 230). Current evidence suggests a slightly later settlement for Shetland: the earliest site at West Voe is dated to the late 5th millennium cal вс (Melton 2009). As in the Western Isles, the first archaeological 
R.R. Bishop et al. DEFORESTATION \& HUMAN AGENCY, WESTERN ISLES OF SCOTLAND

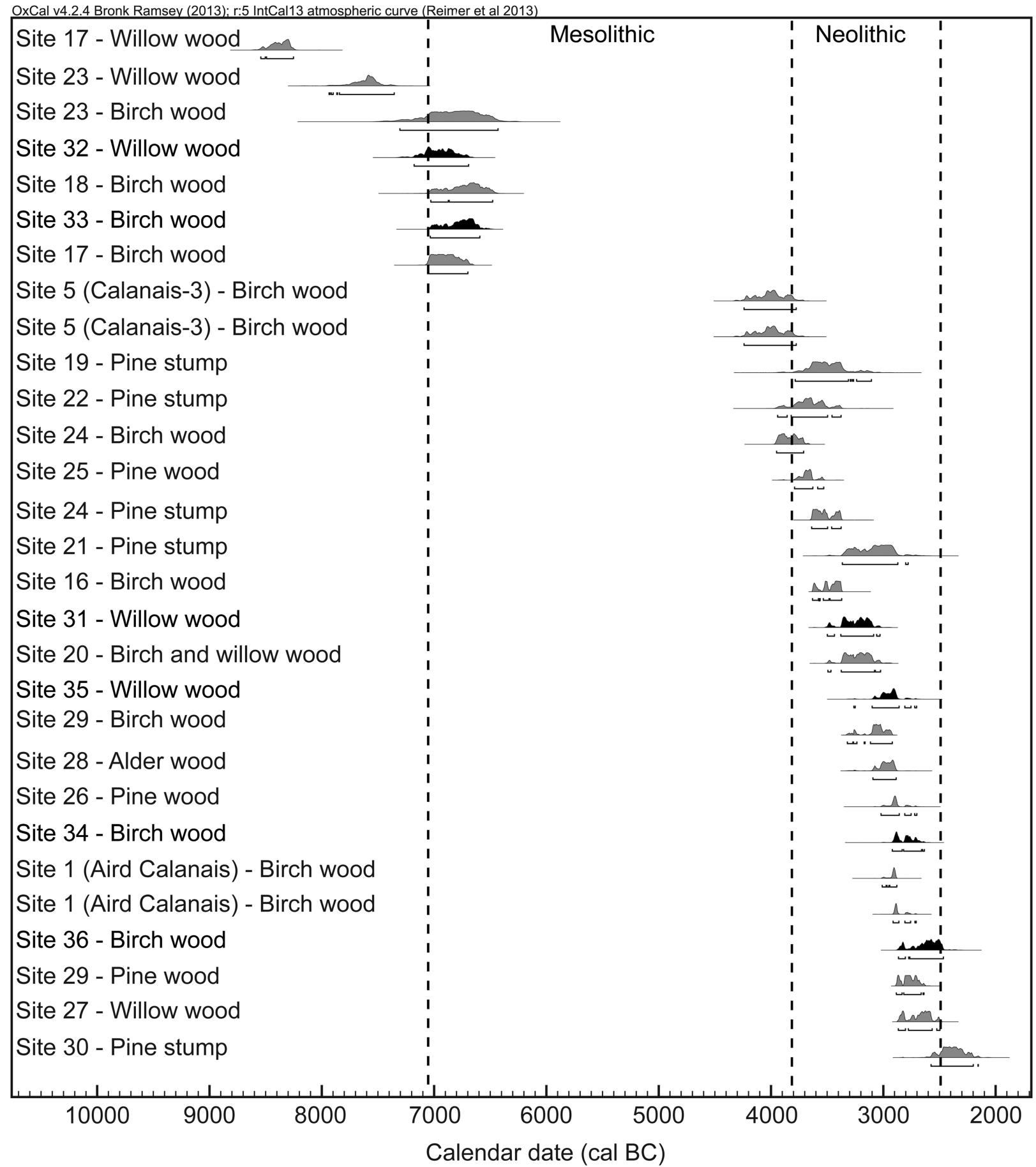

Fig. 15 .

Radiocarbon dated sub-fossil wood from peat sequences in the Western Isles (Bohncke 1988; Fossitt 1996; Wilkins 1984), ordered sequentially. The black distributions are the wood layers located on the Uists, Benbecula, and Barra, and the grey distributions are the wood layers located on Lewis and Harris. Site numbers correspond to those shown in Table 5 and Fig. 2. 
THE PREHISTORIC SOCIETY

TABLE 6: DESCRIPTION OF THE WOOD SITES INCLUDED IN THE REVIEW

\begin{tabular}{|c|c|c|c|c|c|c|}
\hline Site no. & Sample details & Location & Lab.ref & ${ }^{14} \mathrm{C}$ age $B P$ & $\begin{array}{l}\text { Calibrated date } \\
\text { (cal. BC) }\end{array}$ & Reference \\
\hline 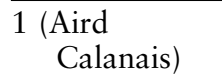 & $\begin{array}{l}\text { Birch branch layer } \\
\text { within peat }\end{array}$ & Lewis & SUERC-24892 & $4245 \pm 30$ & $2914-2708$ & This paper \\
\hline 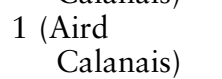 & $\begin{array}{l}\text { Birch branch layer } \\
\text { within peat }\end{array}$ & Lewis & SUERC-24893 & $4300 \pm 30$ & $3011-2880$ & This paper \\
\hline 5 (Callanish-3) & $\begin{array}{l}\text { Birch branch layer } \\
\text { within peat }\end{array}$ & Lewis & GU-1150 & $5180 \pm 90$ & $4241-3776$ & Bohncke 1988 \\
\hline 5 (Callanish-3) & $\begin{array}{l}\text { Birch branch layer } \\
\text { within peat }\end{array}$ & Lewis & GU-1151 & $5180 \pm 90$ & $4241-3776$ & Bohncke 1988 \\
\hline 16 & Birch wood within peat & Lewis & Q-2739 & $4700 \pm 35$ & $3631-3371$ & Fossitt 1996 \\
\hline 17 & Birch branches within peat & Lewis & Q-2286 & $7980 \pm 55$ & $7052-6700$ & Wilkins 1984 \\
\hline 17 & Willow wood within peat & Lewis & Q-2287 & $9140 \pm 65$ & $8544-8253$ & Wilkins 1984 \\
\hline 18 & Birch branches within peat & Lewis & Birm-1091 & $7830 \pm 100$ & 7030-6479 & Wilkins 1984 \\
\hline 19 & Pine stump within peat & Lewis & Birm-1092 & $4740 \pm 120$ & $3785-3106$ & Wilkins 1984 \\
\hline 20 & $\begin{array}{l}\text { Birch \& willow wood layer } \\
\text { within peat }\end{array}$ & Lewis & GU-7321 & $4530 \pm 60$ & $3494-3025$ & $\begin{array}{l}\text { Rees \& Church } \\
\quad 2000\end{array}$ \\
\hline 21 & Pine stump within peat & Lewis & Birm-1094 & $4390 \pm 100$ & $3366-2780$ & Wilkins 1984 \\
\hline 22 & Pine stump within peat & Lewis & Birm-1093 & $4870 \pm 100$ & 3942-3377 & Wilkins 1984 \\
\hline 23 & Willow wood within peat & Lewis & Birm-1096 & $8550 \pm 100$ & 7936-7355 & Wilkins 1984 \\
\hline 23 & Birch branches within peat & Lewis & Birm-1095 & $7890 \pm 180$ & $7305-6432$ & Wilkins 1984 \\
\hline 24 & Birch branches within peat & Lewis & Q-2288 & $5030 \pm 50$ & $3951-3710$ & Wilkins 1984 \\
\hline 24 & Pine stump within peat & Lewis & Q-2289 & $4740 \pm 50$ & 3639-3376 & Wilkins 1984 \\
\hline 25 & Pine stump within peat & Lewis & Q-2743 & $4885 \pm 55$ & 3791-3531 & Fossitt 1996 \\
\hline 26 & Pine stump within peat & Lewis & Q-2741 & $4275 \pm 45$ & $3021-2702$ & Fossitt 1996 \\
\hline 27 & Willow wood within peat & Lewis & Q-2742 & $4095 \pm 40$ & 2867-2496 & Fossitt 1996 \\
\hline 28 & Alder wood within peat & Lewis & Q-2740 & $4340 \pm 50$ & 3093-2886 & Fossitt 1996 \\
\hline 29 & Birch wood within peat & Lewis & Q-2738 & $4420 \pm 30$ & 3321-2921 & Fossitt 1996 \\
\hline 29 & Pine cones within peat & Lewis & Q-2737 & $4175 \pm 30$ & $2885-2638$ & Fossitt 1996 \\
\hline 30 & Pine stump within peat & Lewis & Birm-1058 & $3910 \pm 70$ & $2576-2155$ & Wilkins 1984 \\
\hline 31 & Willow wood within peat & $\begin{array}{r}\text { North } \\
\text { Uist }\end{array}$ & Q-2682 & $4550 \pm 60$ & $3499-3030$ & Fossitt 1996 \\
\hline 32 & Willow wood within peat & $\begin{array}{r}\text { North } \\
\text { Uist }\end{array}$ & Q-2681 & $8040 \pm 75$ & $7179-6693$ & Fossitt 1996 \\
\hline 33 & Birch wood within peat & $\begin{array}{l}\text { South } \\
\text { Uist }\end{array}$ & Q-2683 & $7870 \pm 70$ & $7035-6593$ & Fossitt 1996 \\
\hline 34 & Birch wood within peat & $\begin{array}{l}\text { South } \\
\text { Uist }\end{array}$ & Q-2680 & $4230 \pm 50$ & 2921-2635 & Fossitt 1996 \\
\hline 35 & Willow wood within peat & $\begin{array}{l}\text { South } \\
\text { Uist }\end{array}$ & Q-2679 & $4310 \pm 60$ & $3263-2704$ & Fossitt 1996 \\
\hline 36 & Birch wood within peat & $\begin{array}{l}\text { South } \\
\text { Uist }\end{array}$ & Q-2678 & $4050 \pm 60$ & $2866-2465$ & Fossitt 1996 \\
\hline
\end{tabular}

Site numbers refer to those in Fig. 2. Uncalibrated radiocarbon dates were calibrated within Oxcal v 4.2 (Bronk Ramsey 2009) using Intcal13 (Reimer et al. 2013)

evidence for grazing mammals on Orkney and Shetland was not until the 4th millennium cal BC (Schulting 2013, 324; no definite red deer bones were recovered from the earliest sites in the region: West Voe, Shetland: Melton 2009 or Links House, Orkney: Dan Lee pers. comm.). This suggests that there were no grazing mammals present in the area prior to the Neolithic. There are hints of potential 'grazing' activity in the pollen record on Shetland prior to the 4th millennium cal $\mathrm{BC}$ (Bennett et al. 1992), possibly representing Mesolithic human activities yet to be confirmed in the archaeological record. If so, Shetland would not be unique: in both the Western Isles and the Faroe Islands, the earliest evidence for human settlement was observed in palaeoenvironmental records decades before the first archaeological discoveries (Edwards \& Sugden 2003,11; Church et al. 2013). 


\section{R.R. Bishop et al. DEFORESTATION \& HUMAN AGENCY, WESTERN ISLES OF SCOTLAND}

The pattern of deforestation in Orkney and Shetland is comparable to the Western Isles. The decline of the birch-hazel woodlands which covered much of Orkney and Shetland in the early post-glacial was diachronous, with major declines occurring both prior to and after the introduction of agriculture, and with woodland resources remaining available for exploitation in many areas throughout the Neolithic period (Bennett et al. 1997; Farrell et al. 2014). Open areas suitable for grazing and the cultivation of cereals in small-scale intensive plots (cf. Jones 2005) would already have existed within the environment without the need for major clearance, and this may have muted the immediate environmental impact of the introduction of farming.

The woodland exploitation strategies employed by the first farmers in the Northern Isles may also have helped to conserve resources. In Orkney, many of the earliest structures were constructed of timber, but in the later Neolithic there was a shift from wood to stone as a construction material, in spite of the fact that woodlands would have remained available for building timber at this time (Farrell et al. 2014). There is also extensive archaeobotanical evidence in Neolithic Orkney for the use of turf/peat as a fuel (Bond 2007b, 160; Bishop et al. 2009, 83; Miller et al. 2016, 498; Rowley-Conwy in prep.) alongside native woods (Dickson 1983; 2000; Bond 2007a; 2007b; Miller et al. 2016). There is greater evidence for the use of driftwood as a fuel than in the Western Isles, with spruce/larch charcoal recovered from several early and late Neolithic sites on Orkney (Knap of Howar: Dickson 1983; Skara Brae: Dickson 2000; Stonehall Farm: Miller et al. 2016, 499). The implementation of a broad fuel exploitation strategy and the shift away from the use of wood for construction could be viewed as deliberate conservation mechanisms.

\section{Faroe Islands}

The earliest evidence for human occupation in Faroe Islands dates to the 4th-6th centuries cal AD. Current evidence suggests that this phase of pre-Norse settlement was small-scale, and perhaps discontinuous, and that the main phase of colonisation was during the Norse period, in the 9th century cal AD (Church et al. 2013).

The Faroe Islands provide an interesting contrast to the Western Isles because the environmental impact of the introduction of farming was relatively slight. At many sites, there was little vegetation change after the Norse colonisation (Lawson et al. 2008), despite the fact that grazing mammals were introduced for the first time (Dugmore et al. 2005, 24). This difference can be explained by the fact that the Faroes were already predominantly treeless prior to human settlement: the islands were covered in a mixture of blanket mire, heathland, grassland, and tall herb communities with very little juniper, birch, and willow (Edwards et al. 2005a; Lawson et al. 2005; 2008). Therefore, the introduction of farming had a very small immediate effect because the relatively treeless environment was less susceptible to degradation by introduced grazing mammals (Lawson et al. 2005; 2008). Indeed, in some areas of the Faroe Islands, tree pollen declined more significantly prior (c. cal AD 250) to the first continuous evidence of human settlement than after it (Hannon et al. 2005), probably reflecting the natural spread of heathland (Lawson et al. 2007a) and/or climate change (Hannon et al. 2001,138; 2005). This supports the suggestion that autogenic soil changes and/or climate change may have played a part in the decline of tree populations in other parts of the North Atlantic region, including the Western Isles (Bennett et al. 1992, 264).

\section{Iceland and Greenland}

In contrast to Atlantic Scotland, the Norse settlers in Iceland and Greenland rapidly cleared significant areas of the native birch-willow scrub woodlands during the initial settlement period (eg, Hallsdóttir 1987; Dugmore et al. 2005; Hallsdóttir \& Caseldine 2005; Edwards et al. 2008; Gauthier et al. 2010). The difference in the speed and scale of the clearance probably relates to the greater scale of the woodland exploitation employed by the first farmers in Iceland and Greenland: the Norse Icelanders and Greenlanders harvested birch on a large scale for charcoal production and almost exclusively used birch wood for fuel (Church et al. 2007a; Bishop 2008; Bold 2012; Mooney 2013; Bishop et al. 2013b; Bishop \& Guðmundsson in prep.).

The greater environmental sensitivities of Iceland and Greenland to human impact also played a role in the scale and rapidity of the woodland decline (Dugmore et al. 2005; Streeter et al. 2015). Though Greenland possessed native grazing mammals such as caribou (reindeer: Rangifer tarandus L.), Iceland lacked indigenous grazing mammals. Consequently, Iceland's 
woodlands were more susceptible to degradation by introduced domesticates (Dugmore et al. 2005). Also, in contrast to the Western Isles, people were absent from Iceland and the first Norse settlement areas in Greenland prior to landnám (ibid.), so there was greater need for rapid clearance to create grazing land.

Despite the relatively rapid woodland decline in Iceland after landnám, pollen evidence provides evidence of substantial pre-settlement woodland decline at some sites, and for a considerable degree of local variation in woodland coverage through time: this highlights the role of climatic and environmental factors in woodland decline in the North Atlantic region (Streeter et al. 2015). The palynological record also shows that woodland survived for hundreds of years after settlement in some parts of Iceland and Greenland (Dugmore et al. 2005; Lawson et al. 2007b; Schofield \& Edwards 2011), particularly in the wider environment away from the Norse farms (Streeter et al. 2015).

Archaeobotanical, palynological, and written evidence also suggests that the Norse undertook some deliberate woodland conservation (Church et al. 2007b; Schofield \& Edwards 2011; Bishop et al. 2013b) by creating areas of coppiced woodlands (Dugmore et al. 2005). Native woods, such as birch and willow were important fuels in the midden deposits at Skútustaðir between the 11th and 20th centuries cal AD (Bold 2012), and in the 17th-19th centuries at the farm at Reykholt (Zutter 2000). Small areas of coppiced woodlands still survive to the present day in Iceland (Dugmore et al. 2005, 31).

Charcoal assemblages from Greenland show a similar pattern. Native species, birch and willow, remained key fuels throughout the Norse period, despite evidence for the increased use of driftwood/ imported woods into the 14th century (Bishop 2008; Bishop et al. 2013b). This shows that even in this more environmentally sensitive setting, the initial introduction of farming did not result in the complete destruction of the woodland because the Norse farmers intervened to ensure its continued availability.

Thus, the evidence for woodland decline from across the North Atlantic region reveals a complex interplay between natural and anthropogenic factors. Throughout the region there is evidence for a decline in woodlands, and in some areas the development of heathland, prior to the introduction of agriculture. This highlights the point that many woodland clearances were created by Mesolithic people, autogenic changes, and/or climate change. Whilst woodland decline often accelerated after the first farmers arrived, in most areas some woodland survived for centuries or millennia after the introduction of farming. The speed and extent of deforestation appears to have been influenced by the differing environmental sensitivities of the different parts of the region to human impact, as well as the presence or absence of endemic grazing fauna and the degree to which the first farmers implemented woodland conservation strategies. This further underlines the point that there was not a straightforward link between the introduction of farming and the destruction of woodlands in the region.

\section{CONCLUSIONS}

The palaeobotanical evidence from Aird Calanais and the wider Calanais area provide important evidence for the timing and mechanisms of woodland decline within the Calanais landscape during the midHolocene. The results show that the first evidence for woodland decline occurred in the 7th-6th millennium cal BC and may have been linked to Mesolithic anthropogenic activities, but the subsequent woodland regeneration suggests this was unrelated to the longterm woodland decline.

The late Neolithic wood layer at Aird Calanais most likely represents birch branches which were fortuitously preserved in the peat during a major phase of localised deforestation, perhaps after the larger branches had been extracted by people as a source of construction material. The combined evidence from the archaeobotanical and palynological assemblages shows that the landscape around Aird Calanais became progressively wetter from the Neolithic onwards and it seems likely this environmental deterioration contributed to the local woodland decline.

The Neolithic woodland decline at Aird Calanais correlates with the first of two major Neolithic birch declines identified in a peat column from close to the Calanais I stone circle, and coincides with the major phase of Neolithic activity at the main Calanais stone circle complex, and with wider evidence for arable and pastoral farming in the area. This suggests that the introduction of Neolithic practices, together with climate change - played a key role in the woodland clearance in the Calanais landscape. Despite the decline in woodlands, much of the landscape around the monument would have remained wooded during the main phase of its use, affecting visibility from the monument. 


\section{R.R. Bishop et al. DEFORESTATION \& HUMAN AGENCY, WESTERN ISLES OF SCOTLAND}

Our synthesis of palaeobotanical evidence from across the Western Isles suggests that the primary woodland decline occurred both prior to and during the Neolithic at many sites. Mesolithic huntergatherers may have played a role in initiating many of the woodland declines, but correlation of the dates of many wood layers with phases of woodland decline between 8600 and $6000 \mathrm{cal}$ BC suggests that peat expansion and climate change were also responsible for many of these declines. Although the extent of direct human involvement in deforesting these landscapes is difficult to identify, archaeological evidence shows that Neolithic people would have accelerated woodland decline by introducing large grazing animals, exploiting deciduous woodlands for construction materials, and expanding naturally open areas for settlement and monument construction.

Nonetheless, much of the Western Isles remained well wooded until after the Neolithic. The archaeobotanical record provides key evidence for the continued availability of woodland resources throughout the Neolithic. Although alternative fuels such as peat and turf were sometimes important, young branches from deciduous trees remained a major source of fuel at most Neolithic sites, with larger deciduous branches/trunks and driftwood predominantly reserved for construction. This firewood selection strategy was relatively sustainable because the native deciduous trees all coppice well and so this would not have had a major impact on woodland.

The evidence from across the North Atlantic further emphasises the key role of early farmers in accelerating deforestation in the region, in particular as a result of the introduction of grazing animals, but strongly supports the idea that it was not the introduction of the farming system per se that resulted in the destruction of woodlands. Tree populations sometimes declined even where people were absent, and the nature of the human impact on the woodlands varied across the region according to the differing underlying environmental sensitivities of each area to human impact, as well as the contrasting woodland exploitation strategies that the different farming communities employed. Where conservation strategies were implemented woodlands persisted for centuries or millennia after the introduction of farming. Thus, though the archaeological evidence shows that the earliest farmers in particular were engaged in a range of activities that would have directly influenced woodland cover, deforestation across the region was protracted, spatially variable, and driven by a range of inter-connected natural and anthropogenic processes.

Acknowledgements: The work was supported by Historic Environment Scotland (Grant Title: 'Final publication and archiving of Uig Landscape Project'; PI: MJC), Durham University and the University of Edinburgh. The authors would like to thank Simon Fraser for alerting us to the site and Rory MacLeod for transporting the samples. Marco Nebbia, Brian Buchanan, Janine Wilson and Linda Bosveld are thanked for assisting with the production of Figures 1, 2, \& 13. We would also like to thank Christopher Bronk Ramsey and Andrew Millard for their invaluable advice and assistance with using OxCal (any errors are our own), Jim Innes for his assistance with using TILIA and Michelle Farrell for helpful discussion on identifying woodland declines in palynological sequences. The authors would like to acknowledge the archaeobotanical work undertaken by Anne Crone (Calanais and Eilean Domhnuill), Robin Inglis (Calanais), Rowena Gale (Screvan Quarry) and Ceren Kabukcu (An Doirlinn) on Neolithic charcoal in the Western Isles and to thank them for their permission to use the data from their unpublished reports. We would also like to thank the following for information, access and permission to use unpublished data and reports: Ian Armit, Coralie Mills and Pam Grinter (Eilean Domhnuill), Kevin Edwards (Loch an t-Sil, Loch Airigh na h-Aon Oidhche, Reineval), Patrick Ashmore (Calanais), Richard Strachan (access to unpublished Callanish reports), Duncan Garrow and Fraser Sturt (An Doirlinn), Jane Downes (Screvan Quarry) and Barbara Brayshay and Ymke Mulder for permission to refer to their unpublished $\mathrm{PhD}$ theses. The authors would also like to acknowledge the work of Tim Lomax, whose $\mathrm{PhD}$ thesis was obtained from the British Library.

\section{SUPPLEMENTARY MATERIAL}

To view supplementary material for this article, please visit https://doi.org/10.1017/ppr.2018.8

\section{BIBLIOGRAPHY}

Armit, I. 1996. The Archaeology of Skye and the Western Isles. Edinburgh: Edinburgh University Press

Armit, I. \& Finlayson, B. 1992. Hunter-gatherers transformed: the transition to agriculture in northern and western Europe. Antiquity 66, 664-76

Ascough, P.L., Church, M.J. \& Cook, G.T. 2017. Marine radiocarbon reservoir effects for the Mesolithic and medieval periods in the Western Isles of Scotland. Radiocarbon 59(1), 17-31

Ashmore, P. 1995. Calanais, the Standing Stones. Stornoway: Urras nan Tursachan

Ashmore, P. 2016. Calanais Survey and Excavation 197988. Edinburgh: Historic Environment Scotland

Austin, P. 2000. The emperor's new garden: woodland, trees and people in the Neolithic of southern Britain. In A.S. Fairbairn (ed.), Plants in Neolithic Britain and Beyond, 63-84. Oxford: Oxbow Books 
Barclay, G. 2003. The Neolithic. In K. Edwards \& I. Ralston (eds), Scotland After the Ice Age: Environment, Archaeology and History, 8000 BC-AD 1000, 127-49. Edinburgh: Edinburgh University Press

Bartington Instruments Ltd nd. Operation Manual for MS2 Magnetic Susceptibility System. Oxford: Bartington Instruments Ltd

Bell, M. \& Noble, G. 2012. Prehistoric woodland ecology. In A.M. Jones, J. Pollard, M.J. Allen \& J. Gardiner (eds), Image, Memory and Monumentality. Archaeological Engagements with the Modern World, 80-92. Oxford: Prehistoric Society \& Oxbow Books

Bennett, K.D., Boreham, S., Sharp, M.J. \& Switsur, V.R. 1992. Holocene history of environment, vegetation and human settlement on Catta Ness, Lunnasting, Shetland. Journal of Ecology 80, 241-73

Bennett, K.D., Bunting, M.J. \& Fossitt, J.A. 1997. Longterm vegetation change in the Western and Northern Isles, Scotland. Botanical Journal of Scotland 49, 127-40

Bennett, K.D., Fossitt, J.A., Sharp, M.J. \& Switsur, V.R. 1990. Holocene vegetational and environmental history at Loch Lang, South Uist, Western Isles, Scotland. New Phytologist 114, 281-98

Birks, H.J.B. \& Madsen, B.J. 1979. Flandrian vegetational history of Little Loch Roag, Isle of Lewis, Scotland. Journal of Ecology 67, 825-42

Bishop, R.R. 2008. Did the Norse Manage Woodlands in Greenland? Unpublished MA dissertation. Department of Archaeology, Durham University

Bishop, R.R., Church, M.J. \& Rowley-Conwy, P.A. 2009. Cereals, fruits and nuts in the Scottish Neolithic. Proceedings of the Society of Antiquaries of Scotland 139, 47-103

Bishop, R.R., Church, M.J. \& Rowley-Conwy, P.A. 2010. Northton, Harris. Discovery and Excavation in Scotland ns 11,178

Bishop, R.R., Church, M.J. \& Rowley-Conwy, P.A. 2011. Northton, Harris. Discovery and Excavation in Scotland ns 12, 185-86

Bishop, R.R., Church, M.J. \& Rowley-Conwy, P.A. 2014. Seeds, fruits and nuts in the Scottish Mesolithic. Proceedings of the Society of Antiquaries of Scotland 143, 9-71

Bishop, R.R., Church, M.J. \& Rowley-Conwy, P.A. 2015. Firewood, food and human niche construction: the potential role of Mesolithic hunter-gatherers in actively structuring Scotland's woodlands. Quaternary Science Reviews 108, 51-75

Bishop, R.R., Church, M.J., Clegg, C., Johnson, L., Piper, S., Rowley-Conwy, P. A. \& Snape-Kennedy, L. 2013a. Tràigh na Beirigh 2. Discovery and Excavation in Scotland ns 14, 198-9

Bishop, R.R., Church, M.J., Dugmore, A.J., Madsen, C.K. \& Møller, N.A. 2013b. A charcoal-rich horizon at Ø69, Greenland: evidence for vegetation burning during the Norse landnám? Journal of Archaeological Science 40, 3890-902

Blockley, S.P.E., Bronk Ramsey, C., Lane, C.S. \& Lotter, A.F. 2008. Improved age modelling approaches as exemplified by the revised chronology for the Central European varved lake Soppensee. Quaternary Science Reviews 27, 61-71

Boardman, S. 1995. Charcoal and charred plant macrofossils. In K. Branigan \& P. Foster (eds), Barra: Archaeological research on Ben Tangaval, 149-57. Sheffield: Sheffield Academic Press

Bogaard, A. \& Jones, G. 2007. Neolithic farming in Britain and central Europe: contrast or continuity? Proceedings of the British Academy 144, 357-75

Bohncke, S.J.P. 1988. Vegetation and habitation history of the Callanish area, Isle of Lewis, Scotland. In H.H. Birks, H.J.B. Birks, P.E. Kaland \& D. Moe (eds), The Cultural Landscape: Past, present and future, 445-61. Cambridge: Cambridge University Press

Bohncke, S.J.P., Ashmore, P.J. \& Tipping, R. 2016. Palaeoenvironment. In P. Ashmore (ed.), Calanais Survey and Excavation 1979-88, 822-94. Edinburgh: Historic Environment Scotland

Bold, R. 2012. Norse Utilisation of Archaeobotanical Resources within the Mývatnssveit Locale, Northern Iceland. Unpublished MSc dissertation. Department of Archaeology, Durham University

Bond, J.M. 2007a. The plant remains. In J. Hunter, Investigations in Sanday, Orkney, Vol. 1: Excavations at Pool, Sanday. A Multi-period Settlement from Neolithic to Late Norse Times, 171-207. Kirkwall: The Orcadian \& Historic Scotland

Bond, J.M. 2007b. Plant remains. In S.J. Dockrill, Investigations in Sanday, Orkney. Vol. 2: Tofts Ness, Sanday. An Island Landscape through Three Thousand Years of Prehistory, 164-9. Kirkwall: The Orcadian \& Historic Scotland

Boyd, W.E. 1988. Methodological problems in the analysis of fossil non-artifactual wood assemblages from archaeological sites. Journal of Archaeological Science 15, 603-19

Bradley, R. 1998. The Significance of Monuments. On Shaping of Human Experience in Neolithic and Bronze Age Europe. London: Routledge

Bradley, R. 2002. The land, the sky and the Scottish stone circle. In C. Scarre (ed.), Monuments and Landscape in Atlantic Europe: Perception and Society During the Neolithic and Early Bronze Age, 122-38. London: Routledge

Bradshaw, R.H.W. 1981. Modern pollen-representation factors for woods in south-east England. Journal of Ecology 69, 45-70

Branigan, K. \& Foster, P. 1995. Barra: Archaeological research on Ben Tangaval. Sheffield: Sheffield Academic Press

Brayshay, B. 1992. Pollen Analysis and the Vegetational History of Barra and South Uist in the Outer Hebrides, Scotland. Unpublished $\mathrm{PhD}$ thesis, Department of Archaeology, University of Sheffield

Brayshay, B. \& Edwards, K. 1996. Late-glacial and Holocene vegetational history of South Uist and Barra. In D. Gilbertson, M. Kent \& J. Grattan (eds), The Outer Hebrides. The Last 14,000 Years, 13-26. Sheffield: Sheffield Academic Press 


\section{R.R. Bishop et al. DEFORESTATION \& HUMAN AGENCY, WESTERN ISLES OF SCOTLAND}

Bronk Ramsey, C. 2008. Deposition models for chronological records. Quaternary Science Reviews 27, 42-60

Bronk Ramsey, C. 2009. Bayesian analysis of radiocarbon dates. Radiocarbon 51, 337-60

Brown, T. 1997. Clearances and clearings: deforestation in Mesolithic/Neolithic Britain. Oxford Journal of Archaeology 16, 133-46

Bunting, J.M. 2002. Detecting woodland remnants in cultural landscapes: modern pollen deposition around small woodlands in northwest Scotland. The Holocene 12, 291-301

Bunting, M.J., Gaillard, M.J., Sugita, S., Middleton, R. \& Broström, A. 2004. Vegetation structure and pollen source area. The Holocene 14, 651-60

Bunting, M.J. \& Farrell, M. 2017. Seeing the wood for the trees: recent advances in the reconstruction of woodland in archaeological landscapes using pollen data. Environmental Archaeology. doi/abs/ 10.1080/14614103. 2017.1377405

Chabal, L. 1990. L' etude paléo-écologique de sites protohistoriques à partir des charbons de bois: la question de l'unité de mesure. Dénombrement de fragments ou pesées? In T. Hackens, A.V. Munaut \& C. Ti1l (eds), Wood and Archaeology (PACT 22), 189-205. Strasbourg: Conseil de l'Europe

Church, M.J. 2006. The vegetation history of the Western Isles. In Simpson et al. (eds), 2006, 4-9

Church, M. \& Cressey, M. 2003. Carbonized plant macrofossils, 22-3. In A. Dunwell, M. Johnson \& I. Armit (eds), Excavations at Geirisclett chambered cairn, North Uist, Western Isles. Proceedings of the Society of Antiquaries of Scotland 133, 1-33

Church, M.J. \& Rowley-Conwy, P.A. 2013. Pabaigh Mòr. Discovery and Excavation in Scotland ns 14, 198

Church, M.J., Arge, S.V., Brewington, S., McGovern, T.H., Woollett, J.M., Perdikaris, S., Lawson, I.T., Cook, G.T., Amundsen, C., Harrison, R., Krivogorskaya, Y. \& Dunbar, E. 2005. Puffins, pigs, cod and barley: Palaeoeconomy at Undir Junkarinsfløtti, Sandoy, Faroe Islands. Environmental Archaeology 10, 179-97

Church, M.J., Arge, S.V., Edwards, K.J., Ascough, P.L., Bond, J.M., Cook, G.T., Dockrill, S.J., Dugmore, A.J., McGovern, T.H., Nesbitt, C. \& Simpson, I.A. 2013. The Vikings were not the first colonizers of the Faroe Islands. Quaternary Science Reviews 77, 228-32

Church, M.J., Bishop, R.R., Blake, E., Nesbitt, C., Perri, A., Piper, S. \& Rowley-Conwy, P.A. 2011a. Temple Bay. Discovery and Excavation in Scotland ns 12, 187

Church, M.J., Bishop, R.R., Blake, E., Nesbitt, C., Perri, A., Piper, S. \& Rowley-Conwy, P.A. 2011b. Tràigh na Beirigh. Discovery and Excavation in Scotland ns 12, 194-5

Church, M.J., Bishop, R.R., Blake, E., Nesbitt, C., Perri, A., Piper, S. \& Rowley-Conwy, P.A. 2012a. Temple Bay. Discovery and Excavation in Scotland ns 13, 186

Church, M.J., Bishop, R.R., Blake, E., Nesbitt, C., Perri, A., Piper, S., Rowley-Conwy, P. A., Snape-Kennedy, L. \& Walker, J. 2012b. Tràigh na Beirigh 1. Discovery and Excavation in Scotland ns 13, 190
Church, M.J., Dugmore, A.J., Mairs, K.-A., Millard, A., Cook, G.T., Sveinbjarnardóttir, G., Ascough, P.A., Newton, A.J. \& Roucoux, K. 2007a. Timing and mechanisms of deforestation of the settlement period in Eyjafjallsveit, southern Iceland. Radiocarbon 49, 659-72 Church, M.J., Peters, C.P. \& Batt, C.M. 2007b. Sourcing fire ash on archaeological sites in the Western and Northern Isles of Scotland, using mineral magnetism. Geoarchaeology 22, 747-74

Coles, G.M. 1993a. Cnoc an Tursa (Uig Parish). Discovery and Excavation in Scotland 1993, 110-11

Coles, G.M. 1993b. Callanish Farm (Uig Parish). Discovery and Excavation in Scotland 1993, 111-13

Coles, G.M. \& Burgess, C.P.G. 1994. Callanish Environs Survey (Uig Parish). Discovery and Excavation in Scotland 1994, 96

Coles, G.M., Church, M.J., Harding, D.W. \& Inglis, R. 1998. Calanais Farm (Uig Parish). Discovery and Excavation in Scotland 1998, 105

Cowie, T. 1994. Coastal Erosion and Archaeology in Lewis and Harris. Unpublished Report for Historic Scotland

Crone, A. 1993a. Excavation and survey of sub-peat features of Neolithic, Bronze and Iron Age date at Bharpa Carinish, North Uist, Scotland. Proceedings of the Society of Antiquaries of Scotland 59, 361-82

Crone, A. 1993b. Charcoal, 376 in A. Crone (ed.), Excavation and survey of sub-peat features of Neolithic, Bronze and Iron Age Date at Bharpa Carinish, North Uist, Scotland. Proceedings of the Society of Antiquaries of Scotland 59, 361-82

Crone, A. 2000. Analysis of the carbonised and waterlogged wood. In P. Grinter \& C.M. Mills (eds), Eilean Dombnuill, Loch Olabhat, North Uist: Neolithic subsistence strategy and environment. Unpublished Report, AOC Archaeology, Edinburgh

Cummings, V. \& Whittle, A. 2004. Places of Special Virtue. Megaliths in the Neolithic landscapes of Wales. Oxford: Oxbow Books

Curtis, R. \& Curtis, M. 1994. Callanish: the Stones, the moon and the sacred landscape. Callanish: self published

Dearing, J. 1994. Environmental Magnetic Susceptibility. Kenilworth: Chi Publishing

Diamond, J. 2005. Collapse: How societies choose to fail or survive. London: Penguin

Dickson, C. 1983. Appendix 9: Macroscopic plant remains from Knap of Howar, Orkney, 114-15 in A. Ritchie, Excavation of a Neolithic farmstead at Knap of Howar, Papa Westray, Orkney. Proceedings of the Society of Antiquaries of Scotland 113, 40-141

Dickson, C. 2000. The decline of woodland in Orkney: early Neolithic to late Iron Age. In R.A. Nicholson \& T.P. O'Connor (eds), People as an Agent of Environmental Change, 37-44. Oxford: Oxbow Books

Dickson, J.H. 1992. North American driftwood, especially Picea (spruce), from archaeological sites in the Hebrides and Northern Isles of Scotland. Review of Palaeobotany and Palynology 73, 49-56

Downes, J. \& Badcock, A. 1999. Berneray Causeway: Archaeological Watching Brief and Excavations at 
Screvan \& Otternish (North Uist) and Aird Ma-Rhuibhe (Berneray): Final report. Unpublished Report, ARCUS, Sheffield, UK

Dugmore, A.J., Church, M.J., Buckland, P.C., Edwards, K. J., Lawson, I., McGovern, T.H., Panagiotakopulu, E., Simpson, I.A., Skidmore, P. \& Sveinbjarnardóttir, G. 2005. The Norse landnám on the North Atlantic islands: An environmental impact assessment. Polar Record 41, 21-37

Duigan, C.A. \& Birks, H.H. 2000. The late-glacial and early-Holocene palaeoecology of cladoceran microfossil assemblages at Krakenes, western Norway, with a quantitative reconstruction of temperature changes. Journal of Palaeolimnology 23, 67-76

Dunwell, A., Johnson, M. \& Armit, I. 2003. Excavations at Geirisclett chambered cairn, North Uist, Western Isles. Proceedings of the Society of Antiquaries of Scotland 133, 1-33

Edvardsson, J., Linderson, H., Rundgren, M. \& Hammarlund, D. 2012. Holocene peatland development and hydrological variability inferred from bog-pine dendrochronology and peat stratigraphy a case study from southern Sweden. Journal of Quaternary Science 27, $553-63$

Edwards, K.J. 1996. A Mesolithic of the Western and Northern Isles of Scotland? Evidence from pollen and charcoal. In T. Pollard \& A. Morrison (eds), The Early Prehistory of Scotland, 23-38. Edinburgh: Edinburgh University Press

Edwards, K. J. \& Sugden, H. 2003. Palynological visibility and the Mesolithic colonisation of the Hebrides, Scotland. In L. Larsson, H. Kindgren, K. Knutsson, D. Loeffler \& A. Åkerlund, (eds), Mesolithic on the Move, 11-19. Oxford: Oxbow Books

Edwards, K.J., Schofield, J.E. \& Mauquoy, D. 2008. High resolution palaeoenvironmental and chronological investigations of Norse landnám at Tasiusaq, Eastern Settlement, Greenland. Quaternary Research 69, 1-15

Edwards, K.J., Whittington, G. \& Hirons, K.R. 1995. The relationship between fire and long-term wet heath development in South Uist, Outer Hebrides, Scotland. In D.B.A. Thompson, A. Hester \& M.B. Usher, Heaths and Moorlands: Cultural landscapes, 11-19. Edinburgh: HMSO

Edwards, K.J., Borthwick, D., Cook, G., Dugmore, A.J., Mairs, K.-A., Church, M.J., Simpson, I.A. \& Adderley, W. P. 2005a. A hypothesis-based approach to landscape change in Suduroy, Faroe Islands. Human Ecology 33, 621-50

Edwards, K. J., Whittington, G. \& Ritchie, W. 2005b. The possible role of humans in the early stages of machair evolution: palaeoenvironmental investigations in the Outer Hebrides, Scotland. Journal of Archaeological Science 32, 435-49

Edwards, K.J., Mulder, Y., Lomax, T.A., Whittington, G. \& Hirons, K.R. 2000. Human environmental interactions in prehistoric landscapes: the example of the Outer Hebrides. In D. Hooke (ed.), Landscape: The richest historical record, 13-45. Amesbury: Society for Landscape Studies
Fairnell, E.H. \& Barrett, J.H. 2007. Fur-bearing species and Scottish islands. Journal of Archaeological Science 34, 463-84

Farrell, M., Bunting, J.M., Lee, D.H.J. \& Thomas, A. 2014. Neolithic settlement at the woodland's edge: palynological data and timber architecture in Orkney, Scotland. Journal of Archaeological Science 51, 225-36

Finlay, J. 2006. Faunal remains. In Simpson et al. (eds), 2006, 75-8

Fossitt, J.A. 1994. Modern pollen rain in the northwest of the British Isles. The Holocene 4, 365-76

Fossitt, J.A. 1996. Late Quaternary vegetation history of the Western Isles of Scotland. New Phytologist 132, $171-96$

Fyfe, R., Roberts, N. \& Woodbridge, J. 2010. A pollenbased pseudobiomisation approach to anthropogenic land-cover change. The Holocene 20, 1165-71

Fyfe, R. M., Twiddle, C., Sugita, S., Gaillard, M., Barratt, P., Caseldine, C. J., Dodson, J., Edwards, K. J., Farrell, M., Froyd, C., Grant, M. J., Huckerby, E., Innes, J. B., Shaw, H. \& Waller, M. 2013. The Holocene vegetation cover of Britain and Ireland: overcoming problems of scale and discerning patterns of openness. Quaternary Science Reviews 73, 132-48

Gale, R. 1999. Environmental evidence. In J. Downes \& A. Badcock (eds), Berneray Causeway. Archaeological Watching Brief and Excavations at Screvan \& Otternish (North Uist) and Aird Ma-Rhuibhe (Berneray): Final Report, 42-4. Sheffield: ARCUS

Garrow, D. \& Sturt, F. (eds). (2017). Neolithic Stepping Stones: Excavation and survey within the western seaways of Britain 2008-2014. Oxford: Oxbow Books

Gauthier, E., Bichet, V., Massa, C., Petit, C., Vannière, B. \& Hervé, R. 2010. Pollen and non-pollen palynomorph evidence of medieval farming activities in south- western Greenland. Vegetation History \& Archaeobotany 19, 427-38

Gearey, B. \& Gilbertson, D. 1997. Pollen taphonomy of trees in a windy climate: Northbay Plantation, Barra, Outer Hebrides. Scottish Geographical Magazine 113, 113-20

Gillings, M. \& Wheatley, D. 2001. Seeing is not believing: Unresolved issues in archaeological visibility analysis. In B. Slapšak (ed.), On the Good Use of Geographical Information Systems in Archaeological Landscape Studies, 25-36. Luxembourg: Office for Official Publications of the European Communities

Gregory, R.A., Murphy, E.M., Church, M.J., Edwards, K.J., Guttmann, E.B. \& Simpson, D.A. 2005. Archaeological evidence for the first Mesolithic occupation of the Western Isles of Scotland. The Holocene 15, 944-50

Green, F.H.W. 1964. The climate of Scotland. In J.H. Burnett (ed.), The Vegetation of Scotland, 15-35. Edinburgh \& London: Oliver and Boyd

Guðmundsson, G. 2009. The plant remains. In G. Lucas (ed.), Hofstaðir: Excavations of a Viking Age feasting hall in north eastern Iceland, 322-34. Reykjavik: Institute of Archaeology

Haggarty, A. 1991. Machrie Moor, Arran: recent excavations at two stone circles. Proceedings of the Society of Antiquaries of Scotland 121, 51-94

Hallsdóttir, M. 1987. Pollen analytical studies of human influence on vegetation in relation to the Landnám tephra 


\section{R.R. Bishop et al. DEFORESTATION \& HUMAN AGENCY, WESTERN ISLES OF SCOTLAND}

layer in southwest Iceland. LUNDQUA Thesis 18. Lund: Lund University, Department of Quaternary Geology

Hallsdóttir, M. \& Caseldine, C.J. 2005. The Holocene vegetation history of Iceland, state-of-the-art and future research. In C. Caseldine, A. Russell, J. Hardardóttir \& Ó. Knudsen (eds), Iceland - Modern Processes and Past Environments, 319-34. Amsterdam: Elsevier

Hamilton-Dyer, S. 2005. Faunal remains. In Simpson et al. (eds), 2006, 33-5

Hannon, G.E., Bradshaw, R.H.W., Bradshaw, E.G., Snowball, I. \& Wastegård, S. 2005. Climate change and human settlement as drivers of late-Holocene vegetational change in the Faroe Islands. The Holocene 15, 639-47

Hannon, G.E., Wastegård, S., Bradshaw, E. \& Bradshaw, R. H.W. 2001. Human impact and landscape degradation on the Faroe Islands. Biology and Environment: Proceedings of the Royal Irish Academy 101B, 129-39

Heiri, O., Lotter, A.F. \& Lemcke, G. 2001. Loss on ignition as a method for estimating organic and carbonate content in sediments: reproducibility and comparability of results. Journal of Paleolimnology 25, 101-10

Inglis, R. \& Crone, A. 2016. Macroplant. In Ashmore 2016, 895-939

Johnson, M.J., Flitcroft, C. \& Coles, G.M. 2000. Calanais farm (Uig Parish). Discovery and Excavation in Scotland ns 1, 107 Jones, M. 1991. Sampling in palaeoethnobotany. In W. Van Zeist, K. Wasylikowa \& K. Behre (eds), Progress in Old World Palaeoethnobotany, 53-62. Rotterdam: Balkema

Jones, G. 2005. Garden cultivation of staple crops and its implications for settlement location and continuity. World Archaeology 37, 164-76

Jones, R.L. 1979. Vegetational studies. In C. Renfrew (ed.), Investigations in Orkney, 21-8. London: Society of Antiquaries of London

Kabukcu, C., Jones, J. \& Sturt, F. 2017. Environmental evidence. In D. Garrow \& F. Sturt (eds), Neolithic Stepping Stones: Excavation and survey within the western seaways of Britain 2008-2014, 194-200. Oxford: Oxbow Books

Kenward, H.K., Hall, A.R. \& Jones, A.K.G. 1980. A tested set of techniques for the extraction of plant and animal macrofossils from waterlogged archaeological deposits. Science and Archaeology 22, 3-15

Kitchener, A.C., Bonsall, C. \& Bartosiewicz, L. 2004. Missing mammals from Mesolithic middens: a comparison of the fossil and archaeological records from Scotland. In A. Saville (ed.), Mesolithic Scotland and its Neighbours, 73-82. Edinburgh: Society of Antiquaries of Scotland

Lawson, I.T., Church, M.J., Edwards, K.J., Cook, G.T. \& Dugmore, A.J. 2007a. Peat initiation in the Faroe Islands: climate change, pedogenesis or human impact? Earth and Environmental Science Transactions of the Royal Society of Edinburgh 98, 15-28

Lawson, I.T., Church, M.J., McGovern, T.H., Arge, S.V., Woollett, J., Edwards, K.J., Gathorne-Hardy, F.J., Dugmore, A.J., Cook, G., Mairs, K., Thomson, A.M. \& Sveinbjarnardóttir, G. 2005. Historical ecology on Sandoy, Faroe Islands: Palaeoenvironmental and archaeological perspectives. Human Ecology 33(5), 651-84
Lawson, I.T., Edwards, K.J., Church, M.J., Newton, A.J., Cook, G.T., Gathorne-Hardy, F.J. \& Dugmore, A.J. 2008. Human impact on an island ecosystem: pollen data from Sandoy, Faroe Islands. Journal of Biogeography $35,1130-52$

Lawson, I.T., Gathorne-Hardy, F.J., Church, M.J., Newton, A.J., Edwards, K.J. \& Dugmore, A.J. 2007b. Environmental impacts of the Norse settlement: palaeoenvironmental data from Helluvaðstörn, Mývatnssveit, northern Iceland. Boreas 36, 1-19

Lee, D. \& Woodward, N. 2009. Links House, Stronsay, Orkney. Excavations (Phase III). Data Structure Report. Unpublished report. ORCA. Kirkwall

Lomax, T.M. 1997. Holocene Vegetation History and Human Impact in the Western Lewis, Scotland. Unpublished PhD thesis, University of Birmingham

Mackenzie, N.A. 2000. Low Alpine, Subalpine and Coastal Scrub Communities in Scotland. Highland Birchwoods. Littleburn: Munlochy

McGeever, A.H. \& Mitchell, F.J.G. 2015. Pine stumps in Irish peats: is their occurrence a valid proxy climate indicator? Journal of Quaternary Science 30, 489-96

McGovern, T.H., Bigelow, G., Amorosi, T. \& Russell, D. 1988. Northern islands, human error, and environmental degradation: a view of social and ecological change in the medieval North Atlantic. Human Ecology 16, 225-70

McHardy, I., Barrowman, C. \& MacLeod, M. 2009. STAC: the Severe Terrain Archaeological Campaign investigation of stack sites of the Isle of Lewis 20032005. Scottish Archaeological Internet Report 36

Melton, N.D. 2009. Shells, seals and ceramics: an evaluation of a midden at West Voe, Sumburgh, Shetland, 20042005. In S. McCartan, P. Woodman, R. Schulting \& G. Warren (eds), Mesolithic Horizons: Papers presented at the seventh international conference on the Mesolithic in Europe, Belfast 2005, 184-9. Oxford: Oxbow Books

Miller, J., Ramsay, S., Alldritt, D. \& Bending, J. 2016. Bay of Firth environments from the 2nd to 4th Millennium BC: the evidence from Stonehall, Wideford Hill, Crossiecrown, Knowes of Trotty, Varme Dale and Brae of Smerquoy. In C. Richards \& R. Jones (eds), The Development of Neolithic House Societies in Orkney. Investigations in the Bay of Firth, Mainland, Orkney (1994-2014), 495-519. Oxford: Windgather Press

Miller, N.F. 1985. Paleoethnobotanical evidence for deforestation in ancient Iran: A case study of Urban Malyan. Journal of Ethnobiology 5, 1-19

Mills, C.M., Armit, I., Edwards, K.J., Grinter, P. \& Mulder, Y. 2004. Neolithic land-use and environmental degradation: a study from the Western Isles of Scotland. Antiquity 78, 886-95

Mooney, D.E. 2013. The Use and Control of Wood Resources in Viking Age and Medieval Iceland. Unpublished $\mathrm{PhD}$ thesis, Department of Archaeology, University of Aberdeen Moore, J. 1996. Damp squib: how to fire a major deciduous forest in an inclement climate. In T. Pollard \& A. Morrison (eds), The Early Prehistory of Scotland, 6273. Edinburgh: Edinburgh University Press 
Moore, P.D., Webb, J.A. \& Collinson, M.A. 1991. Pollen Analysis (2nd edn). London: Blackwell Science

Mulder, Y.L.A. 1999. Aspects of Vegetation and Settlement History in the Outer Hebrides, Scotland. Unpublished $\mathrm{PhD}$ Thesis, Department of Archaeology, University of Sheffield

Mullin, M. \& Pankhurst, R.J. 1991. The flora. In R.J. Pankhurst \& J.M. Mullin (eds), Flora of the Outer Hebrides, 61-185. London: HMSO

Munsell Color 1975. Munsell Soil Color Charts. Baltimore: Munsell Color

Nesbitt, C., Church, M.J. \& Gilmour, S.M.D. 2011. Domestic, industrial, (en)closed? Survey and excavation of a Late Bronze Age/Early Iron Age promontory enclosure at Gob Eirer, Lewis, Western Isles. Proceedings of the Society of Antiquaries of Scotland 141, 31-74

Newell, P.J. 1988. A buried wall in peatland by Sheshader, Isle of Lewis. Proceedings of the Society of Antiquaries of Scotland 118, 79-93

Noble, G. 2006. Neolithic Scotland: Timber, Stone, Earth and Fire. Edinburgh: Edinburgh University Press

Orr, M.Y. 1950. Appendix 1. Charcoal, 24 in W.L. Scott (ed.), Eilean an Tighe: a pottery workshop of the 2nd millennium BC. Proceedings of the Society of Antiquaries of Scotland 85, 1-37

Out, W.A., Vermeeren, C. \& Hänninen, K. 2013. Branch age and diameter: useful criteria for recognising woodland management in the present and past? Journal of Archaeological Science 40, 4083-97

Parnell, A.C., Buck, C.E. \& Doan, T.K. 2011. A review of statistical chronology models for high-resolution, proxybased Holocene palaeoenvironmental reconstruction. Quaternary Science Reviews 30, 2948-60

Rackham, O. 2006. Woodlands. London: Collins

Rees, T. \& Church, M. 2000. Bronze Age timbers from Creag Ruaidh, Achmore, Isle of Lewis. Northern Studies $35,133-50$

Reimer, P. J., Bard, E., Bayliss, A., Beck, J. W., Blackwell, P. G., Bronk Ramsey, C., Grootes, P. M., Guilderson, T. P., Haflidason, H., Hajdas, I., HattŽ, C., Heaton, T. J., Hoffmann, D. L., Hogg, A. G., Hughen, K. A., Kaiser, K. F., Kromer, B., Manning, S. W., Niu, M., Reimer, R. W., Richards, D. A., Scott, E. M., Southon, J. R., Staff, R. A., Turney, C. S. M. \& Plicht, J. van der 2013. IntCal13 and Marine13 radiocarbon age calibration curves $0-50,000$ years cal вр. Radiocarbon 55, 1869-87

Renfrew, C. 1979. Investigations in Orkney. London: Society of Antiquaries of London

Ritchie, A. 1983. Excavation of a Neolithic farmstead at Knap of Howar, Papa Westray, Orkney. Proceedings of the Society of Antiquaries of Scotland 113, 40-121

Ritchie, J.N.G. 1976. The Stones of Stenness, Orkney. Proceedings of the Society of Antiquaries of Scotland 107, $1-60$

Ritchie, W., Whittington, G. \& Edwards, K.J. 2000. Holocene changes in the physiography and vegetation of the Atlantic littoral of the Uists, Outer Hebrides, Scotland. Earth and Environmental Science Transactions of the Royal Society of Edinburgh 92, 121-36
Robinson, D. \& Dickson, J.H. 1988. Vegetational history and land use: a radiocarbon-dated pollen diagram from Machrie Moor, Arran, Scotland. New Phytologist 109, 223-51

Rowley-Conwy, P. 1983. Sedentary hunters: the Ertebølle example. In G.N. Bailey (ed.), Hunter-Gatherer Economy in Prehistory, 111-26. Cambridge: Cambridge University Press

Rowley-Conwy, P. 2011. Westward Ho! The spread of agriculturalism from Central Europe to the Atlantic. Current Anthropology 52, S431-51

Rull, V. 1987. A note on pollen counting in palaeoecology. Pollen and Spores 29, 471-80

Rural Development Service 2006. Technical Advice Note 53: Soil texture. Report, Department for Environment, Food and Rural Affairs (DEFRA). London: UK Government

Schofield, J.E. \& Edwards, K.J. 2011. Grazing impacts and woodland management in Eriksfjord: Betula, coprophilous fungi and the Norse settlement of Greenland. Vegetation History \& Archaeobotany 20, 181-97

Schulting, R. 2013. On the Northwestern fringes: Earlier Neolithic subsistence in Britain and Ireland as seen through faunal remains and stable isotopes. In S. Colledge, J. Conolly, K. Dobney, K. Manning \& S. Shennan (eds), The Origins and Spread of Domestic Animals in Southwest Asia and Europe, 313-38. Alta Mira CA: Left Coast Press

Scottish Natural Heritage (SNH) 2014. Scotland's National Peatland Plan: Working for our Future. Report, Scottish Natural Heritage

Scott, W.L. 1935. The chambered cairn of Clettraval, North Uist. Proceedings of the Society of Antiquaries of Scotland 69, 480-536

Scott, W.L. 1947. The chambered tomb of Unival, North Uist. Proceedings of the Society of Antiquaries of Scotland 82, 1-49

Scott, W.L. 1950. Eilean an Tighe: a pottery workshop of the 2nd millennium BC. Proceedings of the Society of Antiquaries of Scotland 85, 1-37

Serjeantson, D. 1990. The introduction of mammals to the Outer Hebrides and the role of boats in stock management. Anthropozoologica 13, 7-18

Simpson, D.D.A., Murphy, E.M. \& Gregory, R.A. 2006. Excavation at Northton, Isle of Harris. Oxford: British Archaeological Report 408

Smith, H. \& Mulville, J. 2004. Resource management in the Outer Hebrides. In R.A. Housley \& G. Coles (eds), Atlantic Connections and Adaptations: Economies, environments and subsistence in lands bordering the north Atlantic, 48-64. Oxford: Oxbow Books

Snape-Kennedy, L., Church, M.J., Bishop, R.R., Clegg, C., Johnson, L., Piper, S. \& Rowley-Conwy, P.A. 2013. Tràigh na Beirigh 9. Discovery and Excavation in Scotland ns 14, 199

Stace, C.A. 2010. New Flora of the British Isles. Cambridge: Cambridge University Press

Stanton, D.W.G., Mulville, J.A. \& Bruford, M.W. 2016. Colonization of the Scottish islands via long-distance Neolithic transport of red deer (Cervus elaphus). Proceedings of the Royal Society B 283. doi: 10.1098/ rspb.2016.0095 


\section{R.R. Bishop et al. DEFORESTATION \& HUMAN AGENCY, WESTERN ISLES OF SCOTLAND}

Streeter, R.T., Dugmore, A.J., Lawson, I.T., Erlendsson, E. \& Edwards, K. 2015. The onset of the palaeoanthropocene in Iceland: changes in complex natural systems. The Holocene 25, 1662-75

Sugita, S., Gaillard, M.-J. \& Broström, A. 1999. Landscape openness and pollen records: a simulation approach. The Holocene 9, 409-21

Thomas, A. \& Lee, D. 2012. Orkney's first farmers: Early settlement on Wyre. Current Archaeology 268, 12-19

Thomas, J. 1999. Understanding the Neolithic. London: Routledge

Thomas, J. 2013. The Birth of Neolithic Britain: An interpretative account. Oxford: Oxford University Press

Tipping, R. 1994. The form and fate of Scotland's woodlands. Proceedings of the Society of Antiquaries of Scotland 124, 1-54

Tipping, R. 1996. Microscopic charcoal records, inferred human activity and climate change in the Mesolithic of northernmost Scotland. In T. Pollard \& A. Morrison (eds), The Early Prehistory of Scotland, 39-61. Edinburgh: Edinburgh University Press

Tipping, R. 2004. Interpretative issues concerning the driving sources of vegetation change in the early Holocene of the British Isles. In A. Saville (ed.), Mesolithic Scotland and its Neighbours, 45-53. Edinburgh: Society of Antiquaries of Scotland

Tipping, R. \& Tisdall, E. 2004. Continuity, crisis and climate change in the Neolithic and Early Bronze Age periods of north-west Europe. In I.A.G. Shepherd \& G.J. Barclay (eds), Scotland in Ancient Europe, 71-81. Edinburgh: Society of Antiquaries of Scotland

van Geel, B., Buurman, J., Brinkkemper, O., Schelvis, J., Aptroot, A., van Reenen, G. \& Hakbijl, T. 2003.
Environmental reconstruction of a Roman Period settlement site in Uitgeest (The Netherlands), with special reference to coprophilous fungi. Journal of Archaeological Science 30, 873-83

Waller, M.P., Binney, H.A., Bunting, M.J. \& Armitage, R.A. 2005. The interpretation of fen carr pollen diagrams: pollen-vegetation relationships within the fen carr. Review of Palaeobotany and Palynology 133, 179-202

Warren, G. 2005. Mesolithic Lives in Scotland. Gloucestershire: Tempus

Wickham-Jones, C.R. 2004. Structural evidence in the Scottish Mesolithic. In A. Saville (ed.), Mesolithic Scotland and its Neighbours, 229-42. Edinburgh: Society of Antiquaries of Scotland

Wilkins, D.A. 1984. The Flandrian woods of Lewis (Scotland). Journal of Ecology 72, 251-8

Wilmshurst, J.M. \& McGlone, M.S. 2005. Corroded pollen and spores as indicators of changing lake sediment sources and catchment disturbance. Journal of Paleolimnology 34 (4), 503-17

Woodbridge, J., Fyfe, R. M., Roberts, N., Downey, S., Edinborough, K. \& Shennan, S. 2014. The impact of the Neolithic agricultural transition in Britain: a comparison of pollen-based land-cover and archaeological ${ }^{14} \mathrm{C}$ dateinferred population change. Journal of Archaeological Science 51, 216-24

Zori, D., Byock, J., Erlendsson, E., Martin, S., Wake, T. \& Edwards, K.J. 2013. Feasting in Viking Age Iceland: Sustaining a chiefly political economy in a marginal environment. Antiquity 87, 150-65

Zutter, C. 2000. Wood and plant-use in 17th-19th century Iceland: archaeobotanical analysis of Reykholt, western Iceland. Environmental Archaeology 5, 73-82

\section{RÉSUMÉ}

Déforestation et action humaine dans la région de l'Atlantique nord:témoignages archéologiques et paléoenvironnementaux des îles ouest de l'Ecosse, de Rosie R. Bishop, Mike J. Church, Ian T. Lawson, Katherine H. Roucoux, Charlotte O’Brien, Helen Ranner, Andrew J. Heald et Catherine E Flitcroft

Cet article examine la séquence temps et les mécanismes de la déforestation dans les îles ouest de l'Ecosse en se concentrant en particulier sur le paysage autour des cercles de pierres de Calanais, l'un des paysages monumentaux du néolithique final/début de l'âge du bronze les mieux préservés du nord-ouest de l'Europe. Nous présentons de nouveaux témoignages archéologiques et paléo-environnementaux d'une séquence de sol et de tourbe du site de Aird Calanais qui couvre la principale période d'utilisation des cercles Calanais Puis nous nous appuyons sur une nouvelle synthèse de témoignages archéo-botaniques et palynologiques de l'ensemble des îles occidentales et une revue de données comparables de la zone plus étendue de l'Atlantique nord avant d'évaluer le rôle des premières communautés d'agriculteurs dans le défrichement des paysages boisés de la région. Le pollen et des datations au $\mathrm{C}^{14}$ sur le site de Aird Calanais révèlent qu'une couche de branches de bouleaux, datant du néolithique final (2912-2881 cal av.J.-C.),.était contemporaine d'un déclin de la forêt sur le site ainsi que d'une phase majeure d'activité néolithique sur le complexe de cercles de pierre de Calanais. Cependant notre synthèse des témoignages de pollen et de macrofossiles de plantes de l'ensemble des îles occidentales indique que le tableau à travers toutes ces îles était en fait bien plus complexe:la forêt avait décliné à la fois avant, aussi bien que pendant, le néolithique et les bois de feuillus demeuraient suffisamment abondants pour fournir du conbustile. Finalement, nous examinons les implications de ces résultats pour la compréhension des interactions entre premiers agriculteurs et forêt dans le cadre de la région plus étendue de l'Atlantique nord. 


\section{ZUSSAMENFASSUNG}

Entwaldung und menschliches Handeln in der Nordatlantikregion: Archäologische Daten und Paläoumweltdaten von den Western Isles Schottlands, von Rosie R. Bishop, Mike J. Church, Ian T. Lawson, Katherine H. Roucoux, Charlotte O'brien, Helen Ranner, Andrew J. Heald und Catherine E Flitcroft

In diesem Beitrag werden Überlegungen angestellt zum Ablauf und den Mechanismen der Entwaldung von Schottlands Western Isles, wobei insbesondere die Landschaft der Steinkreise von Calanais in den Blick genommen wird, eine der am besten erhaltenen spätneolithischen bis frühbronzezeitlichen Monumentallandschaften in Nordwesteuropa. Wir legen neue archäologische und Paläoumweltdaten aus einer Schichtenfolge von Böden und Torf am Fundplatz Aird Calanais vor, die die Zeit der hauptsächlichen Nutzung der Kreise von Calanais umfasst. Anschließend stellen wir eine neue Synthese archäobotanischer und palynologischer Daten der gesamten Western Isles vor sowie eine Übersicht über vergleichbare Daten des weiteren nordatlantischen Gebiets, bevor wir die Rolle der frühen bäuerlichen Gemeinschaften bei der Auflichtung der Waldlandschaften der Region bewerten. Pollen und Radiokarbondatierung am Fundplatz Aird Calanais zeigen, dass eine Schicht von Birkenzweigen, die ins späte Neolithikum datiert (2912-2881 cal BC), zeitgleich mit dem Rückgang der Bewaldung des Ortes wie auch mit der wichtigsten Phase der neolithischen Nutzung des Komplexes der Steinkreise von Calanais war. Unsere Synthese der Pollen und der pflanzlichen Makroreste von den gesamten Western Isles legt jedoch nahe, dass das Bild in der Inselregion insgesamt deutlich komplexer war: Wälder gingen sowohl vor als auch während des Neolithikums zurück und laubwechselnde Wälder blieben ausreichend ergiebig für die Beschaffung von Brennstoff im Neolithikum. Schließlich erörtern wir, welche Konsequenzen diese Ergebnisse für unser Verständnis der Beziehungen zwischen den ersten Bauern und den Wäldern in der weiteren nordatlantischen Region haben.

\section{RESUMEN}

Deforestación e intervención humana en el norte de la región atlántica: evidencia arqueológica y paleoambiental de las islas Hébridas de Escocia, por Rosie R. Bishop, Mike J. Church, Ian T. Lawson, Katherine H. Roucoux, Charlotte O’brien, Helen Ranner, Andrew J. Heald y Catherine E Flitcroft

En este artículo se consideran la cronología y los mecanismos de deforestación en las islas occidentales de Escocia, centrándose en particular en el paisaje alrededor de los círculos de piedra de Calanais, uno de los paisajes monumentales mejor preservados del Neolítico Final/Bronce Inicial del noroeste de Europa. Se presenta nueva evidencia arqueológica y paleoambiental de una secuencia de suelo y turbera del yacimiento de Aird Calanais, que comprende el principal período de uso de los círculos de Calanais. A partir de esto, y antes de evaluar el papel de las primeras comunidades agrícolas en la limpieza de los paisajes arbolados de la región, se propone una nueva síntesis de la evidencia arqueobotánica y palinológica de las Islas y se revisan los datos comparables a una escala más amplia de la zona del Atlántico Norte. El polen y las dataciones radiocarbónicas del yacimiento de Aird Calanais revelan que un estrato de ramas de abedul, datado en el Neolítico final (29122881 cal BC) fue coetáneo al declive del bosque y a la fase principal de actividad neolítica en el círculo de piedra de Calanais. Sin embargo, nuestra síntesis del polen y de la evidencia macrofósil de plantas a lo largo de las islas sugiere un panorama más complejo: el declive del bosque se produce tanto antes como durante el Neolítico y los bosques de hoja caduca siguen siendo suficientemente abundantes para la obtención de combustible durante el Neolítico. Finalmente, se consideran las implicaciones de estos resultados en nuestra comprensión sobre las interacciones entre los primeros agricultores y los bosques en la amplia región del Atlántico Norte. 